\title{
MARTA HELOISA LOPES
}

Análise da inserção de um Centro de Referência para Imunobiológicos Especiais em hospital universitário: aspectos assistenciais, de ensino e pesquisa

Tese apresentada à Faculdade de Medicina da Universidade de São Paulo para obtenção do título de Professor Livre-Docente junto ao Departamento de Moléstias Infecciosas e

Parasitárias

São Paulo

2005 


\section{AGRADECIMENTOS}

Esta tese sintetiza um longo processo de formação pessoal e profissional.

Processo este alicerçado nos valores e exemplos transmitidos por minha família, e meus mestres, consolidado pelos desafios do dia-a-dia, mantido pelo apoio dos amigos e colegas, e a confiança dos pacientes e alunos.

A todos que participaram desta jornada eu devo muito. Sem eles não teria conseguido caminhar. São tantos que é impossível designá-los nominalmente.

Quero destacar, entretanto, a força e a bravura de minha mãe, a nos conduzir, meus irmãos e eu, com a determinação de que buscássemos sempre o saber, daí adviriam as respostas e o rumo a seguir. O apoio, carinhoso, constante e incondicional do meu marido e de meus filhos.

Quero registrar também, com muito orgulho, que o departamento de Moléstias Infecciosas (MI) e Parasitárias da Faculdade de Medicina da Universidade de São Paulo é o responsável por toda minha formação de especialista em doenças infecciosas e parasitárias. Desde a graduação até os dias de hoje a MI tem sido "minha casa". Nesta casa aprendo, ensino, trabalho, luto; dela alço vôos para outros lugares, enfim é onde eu vivo. Eu devo muito a muitos, mas eu devo tudo às pessoas que conviveram e convivem nesta nossa casa chamada MI. 
"A política da universidade deve combinar o máximo de qualidade acadêmica com o máximo de compromisso social... O que caracterizará o produto, portanto, é a sua qualidade, sua condição de elite, mas o que caracterizará o seu uso é o seu compromisso amplo - a sua condição antielitista".

Cristovam Buarque 
SUMÁRIO 


\section{RESUMO}

As tentativas de proteger os indivíduos contra as doenças por meio de vacinação são muito antigas, e precedem os modernos conceitos da imunologia.

A partir da segunda metade do século XIX, desenvolveram-se os conceitos de virulência e atenuação dos agentes etiológicos, e foram feitas tentativas de prevenir uma doença infecciosa por outros meios, que não pela sua transmissão natural.

O século XX assistiu ao desenvolvimento e uso em grande escala de várias vacinas. Avalia-se que o impacto da vacinação na saúde mundial foi extraordinariamente grande, tendo levado à redução da mortalidade e contribuído para o crescimento da população.

.A Organização Mundial da Saúde e a Organização Pan Americana de Saúde têm exercido importante papel no controle de doenças por meio da vacinação. No Brasil, o Programa Nacional de Imunizações (PNI), do Ministério da Saúde, criado em 1973, alcançou grande êxito nos últimos 30 anos.

$\mathrm{Na}$ época atual em que os avanços tecnológicos propiciam o aparecimento de produtos vacinais de alta complexidade, o desafio que se impõe é que tais produtos possam ser administrados a extensas camadas da população.

A ampliação do uso dos imunógenos envolve a perspectiva de que os conhecimentos disponíveis devem estar ao alcance de todos os profissionais da saúde, para que os procedimentos de imunização sejam corretamente indicados para toda a população. Esta perspectiva inclui não só a vacinação na infância como a de adultos em geral e, em particular, de idosos, de imunodeprimidos e de indivíduos com doenças de base que condicionam o uso de imunógenos específicos.

$\mathrm{Na}$ tentativa de ampliar o acesso aos imunógenos disponíveis, o Programa Nacional de Imunizações estabeleceu, a partir de 1993, um programa de suprimento de imunobiológicos especiais, para grupos específicos da população. Este programa foi instalado nos Centros de Referência para Imunobiológicos Especiais (CRIEs), atualmente espalhados por todos os estados da federação. $O$ Centro de Referência para Imunobiológicos Especiais (CRIE) do Hospital das Clínicas da Faculdade de Medicina da Universidade de São Paulo, instalado em dezembro de 1993, foi o piloto desse programa no Estado de São Paulo. A proposta inicial de localizar os CRIEs em centros médicos universitários que concentram a demanda de pacientes, vinculava estes locais ao ensino das práticas de imunização, considerado prioritário na formação médica.

Esta tese discute a importância e a pertinência da inserção de um Centro de Referência para Imunobiológicos Especiais em um hospital de ensino, e relata o trabalho desenvolvido pela autora, como coordenadora deste Centro, desde sua implantação em 1993. Descreve e analisa a intensa atividade assistencial desenvolvida ao longo de 11 anos de existência, as atividades de ensino e, particularmente, as investigações científicas.

Atuando não só como CRIE, mas também como centro de vacinação geral, o número de imunógenos dispensados passou de 13.587, no primeiro ano de funcionamento, em 1994, para 34.580 em 2004. Foram implantados e 
implementados programas de vacinação para estudantes e profissionais de saúde, viajantes, acidentados com material biológico, pacientes com internação hospitalar prolongada, e grupos específicos de pacientes, tais como transplantados, hemofílicos, portadores do vírus da imunodeficiência adquirida e outros.

Foram, entretanto, as atividades de ensino e os trabalhos de investigação científica que melhor traduziram a ação do CRIE HC SP, o qual se mostrou um espaço propício não só para cursos e para orientação de alunos, tanto de graduação quanto de pós-graduação, mas também para o desenvolvimento de projetos de pesquisa.

São apresentadas as investigações conduzidas pela autora, no CRIE HC $\mathrm{SP}$ e publicadas em revistas científicas. Destacam-se, particularmente, a vacinação de profissionais de saúde acidentados com material biológico, a vacinação de idosos, a vacinação contra varicela em crianças transplantadas renais, e a vacinação em pacientes com infecção pelo vírus da imunodeficiência humana ou com Aids.

Conclui-se, a partir desta experiência conduzida pela autora, que os Centros de Referência para Imunobiológicos Especiais, além das atividades assistenciais, podem ser um importante instrumento de ensino e pesquisa, servindo como pólo de produção e disseminação de conhecimentos. 


\section{SUMMARY}

Attempts to protect individuals from diseases through vaccination remount to ancient times and precede the modern immunology's concepts.

From the second half of the $19^{\text {th }}$ century on, concepts such as virulence and etiological agents' attenuation have emerged, and attempts were made to prevent diseases by other means than the natural transmission.

The $20^{\text {th }}$ century has seen the development and use in large scale of many vaccines. It is evaluated that the impact of vaccination on worldwide health was extraordinarily high, leading to mortality reduction and contributing to population's growth.

The World Health Organization and the Pan American Health Organization have been playing a major role in the control of vaccine preventable diseases. In Brazil, the National Program of Vaccination (Programa Nacional de Imunizações $\mathrm{PNI}$ ), created by the Health Ministry, in 1973, has reached great success in the last 30 years.

Nowadays, with technological advances allowing the appearance of high complexity vaccine products, the challenge faced is to make these products available to extended segments of the population.

The expansion in the use of immunogens involves the perspective that current knowledge should be within all health professionals reach, in order to assure that immunization procedures are adequately indicated to all population. This perspective includes not only childhood vaccination but also for adults in general and, particularly, elders, immunossupressed patients and individuals with other diseases that require the use of specific immunogens.

In an attempt to expand the access to available immunogens, the PNI established, since 1993, a program to supply special immunobiologics to specific groups of the population. This program has been installed in Reference Centers for Special Immunobiologics (Centros de Referência para Imunobiológicos Especiais - CRIEs), now spread throughout all the federation states. The Reference Center of the Hospital das Clínicas, University of São Paulo School of Medicine, installed in December of 1993, was the pilot for the program in the state of São Paulo. The initial proposal of placing the CRIEs in university medical centers, which concentrate patients' demand, linked these places to the teaching of immunization practices, considered of vital importance in medical formation.

This thesis discusses the importance and pertinence of the insertion of a Reference Center for Special Immunobiologics (CRIE) in a teaching hospital, and reports the author's work, as the coordinator of the center, since its implantation in 1993. It is here described and analyzed the author's intense health care activities throughout the 11 years of existence of the center, as well as her teaching and, particularly, her scientific investigation activities.

Functioning not only as a CRIE but also as a general vaccination center, the number of immunogens delivered by the center rose from 13,587 in 1994, its first functioning year, to 34,580 in 2004 . Vaccination programs have been implanted and implemented aiming students and health professionals; travelers; individuals 
injured by biological materials; patients with prolonged hospital stay; specific groups of patients such as transplanted, hemophiliac, HIV positives and others.

However, the teaching activities and the scientific investigation works better illustrated the action of the CRIE HC SP, which revealed to be an adequate place not only to offer courses and to coach students, both from graduation and postgraduation levels, but also to the development of research projects.

The thesis presents the investigations conducted in the CRIE HC SP and published in scientific journals, with special attention to vaccination of health professionals injured by biological material, to elders' vaccination, to vaccination against varicella in kidney transplanted children and to vaccination in patients with human immunodeficiency virus infection or with acquired immunodeficiency syndrome (Aids).

From the experience led by the author, it is concluded that the CRIEs may be an important tool of teaching and research, serving as a center of knowledge production and dissemination. 
Análise da inserção de um Centro de Referência para Imunobiológicos Especiais em hospital universitário: aspectos assistenciais, de ensino e pesquisa.

\section{INTRODUÇÃO}

"O impacto da vacinação na saúde da população mundial é extraordinariamente grande. Com exceção da água potável, nenhuma outra modalidade, nem mesmo os antibióticos, tiveram maior efeito na redução da mortalidade e no crescimento da população" (Plotkin) ${ }^{1}$.

As tentativas de proteger os indivíduos contra as doenças por meio de vacinação são muita antigas, e precedem os modernos conceitos da imunologia.

A técnica de "variolação", que consistia na inoculação de material obtido de lesão pustulosa de paciente com varíola em indivíduos sãos, já era conhecida na China e na Índia provavelmente desde o século $X^{1}$.

A origem precisa desta técnica permanece desconhecida. Atribui-se sua introdução na Inglaterra à Lady Mary Wortley Montagu, em 1721. Esta nobre inglesa observou que muçulmanos de Constantinopla usavam a variolação para se proteger da doença, e ao regressar à Inglaterra difundiu seu uso ${ }^{1}$. A variolação chegou a ser empregada no Brasil, ainda que apenas isoladamente ${ }^{2}$.

Paralelamente $a$ isto havia o conhecimento popular de que ordenhadores de vacas não contraíam a varíola humana, depois de terem a varíola da vaca (causada pelo vírus cowpox, um Orthopoxvirus estreitamente relacionado ao vírus da varíola), doença benigna e disseminada entre os que lidavam com gado ${ }^{3}$. Esta observação levou um criador de gado, o inglês Benjamin Jesty, a inocular deliberadamente sua esposa e dois filhos com material purulento da lesão de vaca, para protegê-los de uma epidemia de varíola ${ }^{1}$. Entretanto, foi o médico inglês, Edward Jenner, em 1796, quem conduziu a primeira experiência científica inoculando um menino com material de uma pústula da lesão de uma mulher, que estava acometida de varíola bovina (cowpox), e posteriormente inoculando, no mesmo menino, material de pústula de varíola humana, sem aparecimento da doença. O trabalho de Jenner, conforme citado por Plotkin ${ }^{1}$, foi publicado em 1798, com o título de "Variolae Vaccinae". O termo vacina se origina de "vacca", em latim.

Desde esta primeira tentativa, documentada cientificamente, de prevenir uma doença infecciosa por outros meios que não a transmissão natural da doença, as idéias de atenuação e virulência foram se desenvolvendo, assim como o conceito de "passagens" do agente imunizante - transmissão de um homem ou animal para outro.

Havia, entretanto, a preocupação de que o material usado como vacina pudesse transmitir outras doenças, como, por exemplo, a sífilis. Por volta de 1850, cientistas alemães, segundo Plotkin ${ }^{1}$, usaram glicerina para matar a bactéria, mas sem alterar a capacidade do material de proteger contra varíola.

Seguindo esta mesma linha de investigação, Louis Pasteur, em 1870, conseguiu a atenuação da bactéria causadora de cólera em galinhas ${ }^{1}$.

Em 1881, Pasteur vacinou 24 ovelhas, uma cabra e seis vacas com bacilos de antraz atenuados e manteve um grupo de animais semelhantes ( 24 ovelhas, 
uma cabra e quatro vacas) não vacinados, como controle. Posteriormente inoculou bacilo virulento de antraz em ambos os grupos. Vinte e quatro de 29 animais não vacinados morreram. Todos os animais vacinados permaneceram saudáveis. Relato citado por Plotkin ${ }^{1}$. Estabelecia assim o conceito do uso de uma forma enfraquecida de um agente etiológico para proporcionar imunidade.

Em 1885, Roux, da equipe de Pasteur, observou que a virulência de cordões espinais de animais infectados pelo vírus da raiva diminuía rapidamente quando eles eram suspensos em ar seco, e se extinguia completamente em 15 dias $^{4}$.

A partir desta observação Pasteur iniciou seus experimentos vacinando cães, por via subcutânea, com suspensão de cordão espinal infectado pelo vírus da raiva. No mesmo ano de 1885, apesar das experiências em cães não serem ainda conclusivas, Pasteur, contrariando a opinião de Roux e outros, vacinou o primeiro paciente, o menino Joseph Meister, contra raiva. O menino, que havia sido gravemente mordido por um cão raivoso, sobreviveu ${ }^{4}$.

Outro passo importante para o desenvolvimento das vacinas foi a descoberta, em 1886, dos americanos Daniel Elmer Salmon e Theobald Smith, de que agentes etiológicos mortos pelo calor, ainda mantinham a capacidade de proteger contra a doença. Desenvolveram uma vacina constituída de "vírus da cólera de suínos" mortos ou inativados. Na verdade este "vírus" era uma bactéria, uma salmonela cólera símile ${ }^{1}$.

As investigações do século XIX iniciaram uma nova era de pesquisas científicas sobre vacinação, introduzindo conceitos tais como atenuação de agentes patológicos e modificações da virulência através de passagens. Mas introduziram também preocupações com restabelecimento da virulência, segurança das vacinas e probabilidade delas transmitirem outras doenças.

Nos primeiros anos do século $X X$ têm início as pesquisas e teorias imunológicas. Em 1908, Paul Erlich recebeu o prêmio Nobel por sua pesquisa relacionada à imunidade ${ }^{1}$. A maioria dos conceitos fundamentais em vacinologia foi, entretanto, introduzida no final do século XIX, precedendo a moderna imunologia.

No início as reações às vacinas bacterianas contra febre tifóide, cólera eram graves, mas a proteção contra as doenças era efetiva. Apesar das reações, e apesar dos acidentes tecnológicos resultando em vacinas virulentas ou contaminadas, o progresso continuou, culminando no desenvolvimento de vacinas contra a difteria, tétano, coqueluche, tuberculose ${ }^{5}$.

Ainda na primeira metade do século $X X$, o desenvolvimento de técnicas para isolamento de vírus constituiu importante avanço, levando à obtenção da vacina contra febre amarela. Mas a era de ouro do desenvolvimento de vacinas tem início em 1949, quando Enders, Robbins e Weller publicam na revista Science, conforme relatado por Plotkin ${ }^{1}$, o crescimento do pólio vírus tipo 2 , cepa Lansing, em cultura de tecido de embrião humano. A adição de antibióticos ao meio permitia a manutenção da cultura por longo tempo. Por este feito, os cientistas receberam o prêmio Nobel, em $1954^{6}$.

A possibilidade da obtenção de vírus em larga escala foi fundamental para o desenvolvimento de novas vacinas. Nas décadas de 50 e 60 do século XX surgiram vacinas vivas atenuadas, obtidas por repetidas passagens do agente 
infeccioso em cultura de tecido, ou hospedeiros animais ${ }^{7,8}$, e vacinas inativadas por agentes químicos, como a formalina ${ }^{9}$.

Os avanços técnico-científicos, desde então, foram extraordinários (tabela 1). Atualmente estão disponíveis comercialmente vacinas constituídas de bactérias e vírus vivos atenuados, de bactérias e vírus inativados, de proteínas virais, de polissacarídeos bacterianos, vacinas conjugadas de proteínas e polissacarídeos, vacinas protéicas recombinantes obtidas por engenharia genética.

Nas chamadas vacinas de nova geração não é usado o patógeno completo, quer sejam vírus, bactérias ou protozoários, atenuados ou inativados. São constituídas de moléculas protéicas obtidas pela técnica de DNA recombinante; peptídeos sintéticos; anticorpos antiidiotipo que mimetizam determinada estrutura original do patógeno ${ }^{10}$.

\section{Tabela 1}

Desenvolvimento de vacinas humanas.

\begin{tabular}{|c|c|c|c|}
\hline Vivas, Atenuadas & Inativadas & $\begin{array}{c}\text { Proteínas ou } \\
\text { polissacarídeos }\end{array}$ & $\begin{array}{c}\text { Engenharia } \\
\text { genética }\end{array}$ \\
\hline \multicolumn{4}{|c|}{ Século XVIII } \\
\hline \multicolumn{4}{|l|}{ Varíola (1798) } \\
\hline \multicolumn{4}{|c|}{ Século XIX } \\
\hline Raiva (1885) & $\begin{array}{l}\text { Febre Tifóide (1896) } \\
\text { Cólera (1896) } \\
\text { Peste (1897) }\end{array}$ & & \\
\hline \multicolumn{4}{|c|}{ Início do Século XX } \\
\hline $\begin{array}{l}\text { BCG (1927) } \\
\text { Febre Amarela (1935) }\end{array}$ & $\begin{array}{l}\text { Coqueluche (1926) } \\
\text { Influenza (1936) } \\
\text { Tifo (1938) }\end{array}$ & $\begin{array}{l}\text { Difteria (1923) } \\
\text { Tétano (1927) }\end{array}$ & \\
\hline \multicolumn{4}{|c|}{ Após 2a Guerra Mundial } \\
\hline $\begin{array}{l}\text { Pólio (oral) } \\
\text { Sarampo } \\
\text { Caxumba } \\
\text { Rubéola } \\
\text { Varicela } \\
\text { Influenza } \\
\text { Rotavírus }\end{array}$ & $\begin{array}{l}\text { Pólio (injetável) } \\
\text { Raiva (cultivo celular) } \\
\text { Encefalite Japonesa } \\
\text { Hepatite A } \\
\text { Cólera }\end{array}$ & $\begin{array}{l}\text { Pneumococo } \\
\text { Meningococo } \\
\text { Haemophilus influenzae } \\
\text { tipo b } \\
\text { Pneumo conjugada } \\
\text { Meningo conjugada } \\
\text { H. influenzae b conjugada } \\
\text { Hepatite B (derivada de } \\
\text { plasma) } \\
\text { Febre tifóide } \\
\text { Coqueluche acelular } \\
\text { Antraz }\end{array}$ & $\begin{array}{l}\text { Hepatite B } \\
\text { recombinante } \\
\text { Coqueluche } \\
\text { acelular (alguns } \\
\text { componentes) } \\
\text { Lyme }\end{array}$ \\
\hline
\end{tabular}

Adaptado de Plotkin SL, Plotkin AS. A short history of vaccination. In: Plotkin S, Orenstein W, editors. Vaccines. $4^{\text {th }}$ ed. Philadelphia: WB Saunders; $2004^{1}$. 
Entretanto, como já salientamos em artigo publicado no jornal "O Estado de São Paulo", em $1995^{11}$, numa época em que os avanços tecnológicos possibilitam o aparecimento de produtos vacinais de alta complexidade, o desafio que se impõe é que tais produtos possam ser administrados a amplas camadas da população mundial.

O Programa Ampliado de Imunização (PAI), conhecido na língua inglesa como Expanded Programme on Immunization (EPI), foi estabelecido em 1974 pela Organização Mundial da Saúde (OMS). Os países que fazem parte das Nações Unidas usualmente seguem suas recomendações, que incluem vacinação rotineira na infância com: BCG, vacina contra poliomielite de vírus vivos atenuados, vacina contra difteria, coqueluche e tétano, vacinas contra sarampo e contra hepatite $B$. A vacina contra febre amarela é recomendada em regiões endêmicas para febre amarela. A vacina conjugada contra Haemophilus influenzae tipo b é recomendada para países com alta incidência da doença. O PAI inclui também a imunização contra tétano de mulheres em idade fértil ${ }^{12}$. Para atingir seu objetivo 0 PAl apresenta um esquema de vacinação de baixo custo. Leva em consideração o nível sócio-econômico da região, os recursos locais e os coeficientes de morbimortalidade ${ }^{13}$.

No ano de 2000 foi formada a "Global Alliance for Vaccines and Immunization" (GAVI), com o intuito de revigorar programas de imunização de países pobres ${ }^{12}$. A GAVI é constituída por vários parceiros globais incluindo: OMS, "United Nations Children's Fund" (UNICEF), Fundação Bill e Melinda Gates, Banco Mundial, Centro de Controle e Prevenção de Doenças (CDC) de Atlanta, dos Estados Unidos da América, entre outros.

Nas Américas, a Organização Pan-Americana da Saúde (OPAS) tem exercido importante papel no controle de doenças por meio da vacinação. As Américas foram a primeira região a erradicar a varíola e sua experiência foi aplicada na erradicação da varíola do mundo.

A partir das lições da varíola, a OPAS estabeleceu que a poliomielite podia ser erradicada das Américas ${ }^{14}$. As Américas receberam o certificado de região livre da transmissão autóctone do poliovírus selvagem, em setembro de 1994. Após mais este sucesso, a OPAS estabeleceu como próxima meta a erradicação do sarampo das Américas. Nos últimos 10 anos, a incidência de sarampo nas Américas diminuiu mais de $99 \%$. O surto ocorrido na Venezuela, no ano de 2002, pode ser considerado o último de transmissão disseminada, endêmica, do vírus do sarampo nas Américas. Os casos ocorridos em 2003 e 2004 estavam direta ou indiretamente ligados à importação do vírus do sarampo de outras regiões ${ }^{15}$.

No Brasil, o Programa Nacional de Imunizações (PNI), do Ministério da Saúde, criado em 1973, alcançou grande êxito nos últimos 30 anos. O Programa Nacional de Imunizações (PNI) foi instituído como forma de "coordenar ações que se caracterizavam, até então, pela descontinuidade, pelo caráter episódico e pela reduzida área de cobertura. Estas ações conduzidas dentro de programas especiais (erradicação da varíola, controle da tuberculose) e como atividades desenvolvidas por iniciativa de governos estaduais, necessitavam de uma coordenação central que lhes proporcionasse sincronia e racionalização" ${ }^{\text {"16 }}$. 
A Lei $n^{\circ} 6259$, de 30/10/75, regulamentada pelo Decreto $n^{\circ} 78231$, de 12/08/76, institucionaliza o PNI, sob a responsabilidade do Ministério da Saúde, e "define competências que podem ser consideradas válidas até o momento:

- Implantar e implementar as ações do Programa, relacionadas com as vacinações de caráter obrigatório.

- Estabelecer critérios e prestar apoio técnico e financeiro à elaboração, implantação e implementação do programa de vacinação.

- Estabelecer normas básicas para a execução das vacinações.

- Supervisionar (...) e avaliar a execução das vacinações no território nacional.

- (...) analisar e divulgar informações referentes ao PNI."16.

"O PNI é orientado por normas técnicas estabelecidas nacionalmente. Essas normas referem-se à conservação, ao transporte e à administração dos imunobiológicos, assim como aos aspectos de programação e avaliação. Para assegurar a aceitação e uniformidade de uso em todo o país, as normas são estabelecidas com a participação dos estados e municípios, por meio dos órgãos responsáveis pela operacionalização do programa"16. Esta participação foi ampliada pela entrada de outras instituições, tais como a Sociedade Brasileira de Pediatria, a Sociedade Brasileira de Medicina Tropical, a Sociedade Brasileira de Infectologia, representadas no Comitê Técnico Assessor em Imunizações, criado pela Portaria $n^{\circ} 389$, de 06/05/91 ${ }^{16}$. (Em 2003 fui indicada para compor o Comitê Técnico Assessor em Imunizações, como representante da Sociedade Brasileira de Infectologia).

O estabelecimento de esquemas vacinais básicos a serem seguidos em todo o país; as compras programadas de imunógenos, em larga escala, e a sistematização no armazenamento e distribuição destes produtos provocaram grande impacto na epidemiologia das doenças imunopreveníveis, no Brasil. Nos últimos 30 anos, as ações planejadas e sistematizadas do PNI levaram ao controle do sarampo, do tétano neonatal e acidental, das formas graves de tuberculose, à acentuada redução de casos de difteria e de coqueluche, e à interrupção da transmissão de poliomielite. O último caso brasileiro de poliomielite ocorreu em 1989, na Paraíba. Em 1994, o Brasil recebeu a certificação do bloqueio da transmissão autóctone do poliovírus selvagem ${ }^{17}$.

A vacina contra sarampo foi introduzida no Brasil em 1967, mas só passou a ser sistematicamente distribuída na rede pública de vacinação a partir de 1973 , com a criação do PNI. Mesmo assim, ainda ocorriam epidemias a cada dois a quatro anos, com significantes morbidade e mortalidade. Na tentativa de enfrentar este importante problema de saúde pública, foi iniciado em 1987, no estado de São Paulo, Programa de Controle do Sarampo, e, em 1992, o Ministério da Saúde do Brasil instituiu o Plano Nacional de Controle e Eliminação do Sarampo. Desde então, vinha ocorrendo gradativa queda na incidência de sarampo.

No final do ano de 1996, entretanto, foi detectado aumento do número de casos na região da grande São Paulo, culminando com uma epidemia em 1997, com 23.909 casos confirmados no Estado de São Paulo e 23 óbitos. Embora elevadas, as coberturas vacinais para sarampo, no Estado, nos anos de 1993 a 1995, não tinham sido homogêneas ${ }^{18}$, permitindo a circulação do vírus selvagem. 
Este fato e o acúmulo de suscetíveis em faixas etárias mais altas, como a de adultos jovens, propiciaram o aparecimento da epidemia.

Em seqüência às medidas adotadas para contenção da epidemia, em junho de 2000 foi realizada campanha nacional em que foram vacinadas, indiscriminadamente, crianças de um a quatro anos de idade, com a vacina dupla viral (contra sarampo e rubéola), alcançando cobertura de $96 \%$ e homogeneidade de $70 \%{ }^{18}$.

Como resultado destas medidas, ocorreu significativa diminuição no número de casos de sarampo, no Estado de São Paulo ${ }^{19}$, como se observa na tabela 2, e também no Brasil. Os últimos casos diagnosticados, tanto no estado como no país, foram importados ${ }^{20}$. 


\section{Tabela 2}

\begin{tabular}{|c|c|c|c|c|}
\hline \multicolumn{5}{|c|}{$\begin{array}{l}\text { CASOS DE SARAMPO CONFIRMADOS, COEFICIENTE DE INCIDÊNCIA (POR } \\
\text { 100.000HAB), ÓBITOS E LETALIDADE } \\
\text { ESTADO DE SÃO PAULO - } 1992 \text { a 2004* }\end{array}$} \\
\hline ANO & CASOS & C.I. & ÓBITOS & LETALIDADE \\
\hline 1992 & 39 & 0,12 & 0 & 0 \\
\hline 1993 & 24 & 0,07 & 0 & 0 \\
\hline 1994 & 13 & 0,04 & 0 & 0 \\
\hline 1995 & 11 & 0,03 & 0 & 0 \\
\hline 1996 & 24 & 0,07 & 0 & 0 \\
\hline 1997 & 23909 & 69,13 & 23 & 0,10 \\
\hline 1998 & 252 & 0,71 & 0 & 0 \\
\hline 1999 & 94 & 0,26 & 0 & 0 \\
\hline 2000 & 10 & 0,02 & 0 & 0 \\
\hline 2001 & $1^{\star *}$ & 0,00 & 0 & 0 \\
\hline 2002 & $1^{\star *}$ & 0,00 & 0 & 0 \\
\hline $2003^{*}$ & 0 & 0,00 & 0 & 0 \\
\hline $2004^{*}$ & 0 & 0,00 & 0 & 0 \\
\hline
\end{tabular}

FONTE: Sistema de Vigilância Epidemiológica - Divisão de Doenças de Transmissão Respiratória DDTR/Centro de Vigilância Epidemiológica - CVE (1992 a 1996)

DDTR/CVE - Fluxo paralelo (1997)

Sistema de Informação de Agravos de Notificação - SINAN + Instituto Adolfo Lutz - IAL (1998 a 2004)

* DADOS PROVISÓRIOS ATÉ 05/01/05

** CASO IMPORTADO DO JAPÃO

C.I.= Coeficiente de incidência. 
Não se observa diminuição no número de casos de outras doenças transmissíveis, como a varicela, cuja prevenção vacinal ainda não é empregada rotineiramente no Estado de São Paulo (tabela 3$)^{21}$.

\section{Tabela 3}

\begin{tabular}{|c|c|c|c|c|}
\hline \multicolumn{5}{|c|}{$\begin{array}{r}\text { CASOS DE VARICELA CONFIRMADOS, COEFICIENTE DE II } \\
\text { 100.000HAB), OBBITOS E LETALIDADE } \\
\text { ESTADO DE SÃO PAULO - } 2002 \text { a 2004* }\end{array}$} \\
\hline ANO & CASOS & C.I. & ÓBITOS & LETALIDADE \\
\hline 2002 & 2284 & 5,98 & 30 & 1,31 \\
\hline 2003 & 49626 & 128,20 & 60 & 0,12 \\
\hline $2004^{\star}$ & 6994 & 17,82 & 4 & 0,06 \\
\hline
\end{tabular}

Fonte: SINAN/DDTR/CVE/SES-SP; Centro de Informações de Saúde - CIS/SEADE; DATASUS/MS.

* Dados atualizados até 05/01/2005.

C.I.= Coeficiente de incidência. 
Nos gráficos a seguir (gráficos 1, 2, 3, 4, 5, 6, 7) observa-se o impacto da vacinação no Brasil.

São apresentados dados de cobertura vacinal obtidos no "site" do DATASUS, cuja fonte é o $\mathrm{PNI}^{22}$, e no "site" da Secretaria de Vigilância em Saúde (SVS) do Ministério da Saúde (MS) do Brasil ${ }^{23}$, cujas fontes são a Coordenação Geral do Programa Nacional de Imunizações (CGPNI) e o Departamento de Vigilância Epidemiológica (DEVEP) da SVS/MS.

A partir das séries históricas de casos das doenças abaixo consideradas e da população residente nos respectivos anos, foi calculada a incidência das doenças imunopreveníveis. As séries históricas de casos das doenças foram obtidas no "site" da SVS, cujas fontes são SVS/MS, Secretarias de Estado da Saúde (SES) e Sistema de Informação de Agravos de Notificação (SINAN) a partir de $1998^{24}$. A população residente nos respectivos anos foi obtida no "site" do DATASUS, cuja fonte é o Instituto Brasileiro de Geografia e Estatística (IBGE) Censos Demográficos e Contagem Populacional ${ }^{25}$.

\section{Gráfico 1}

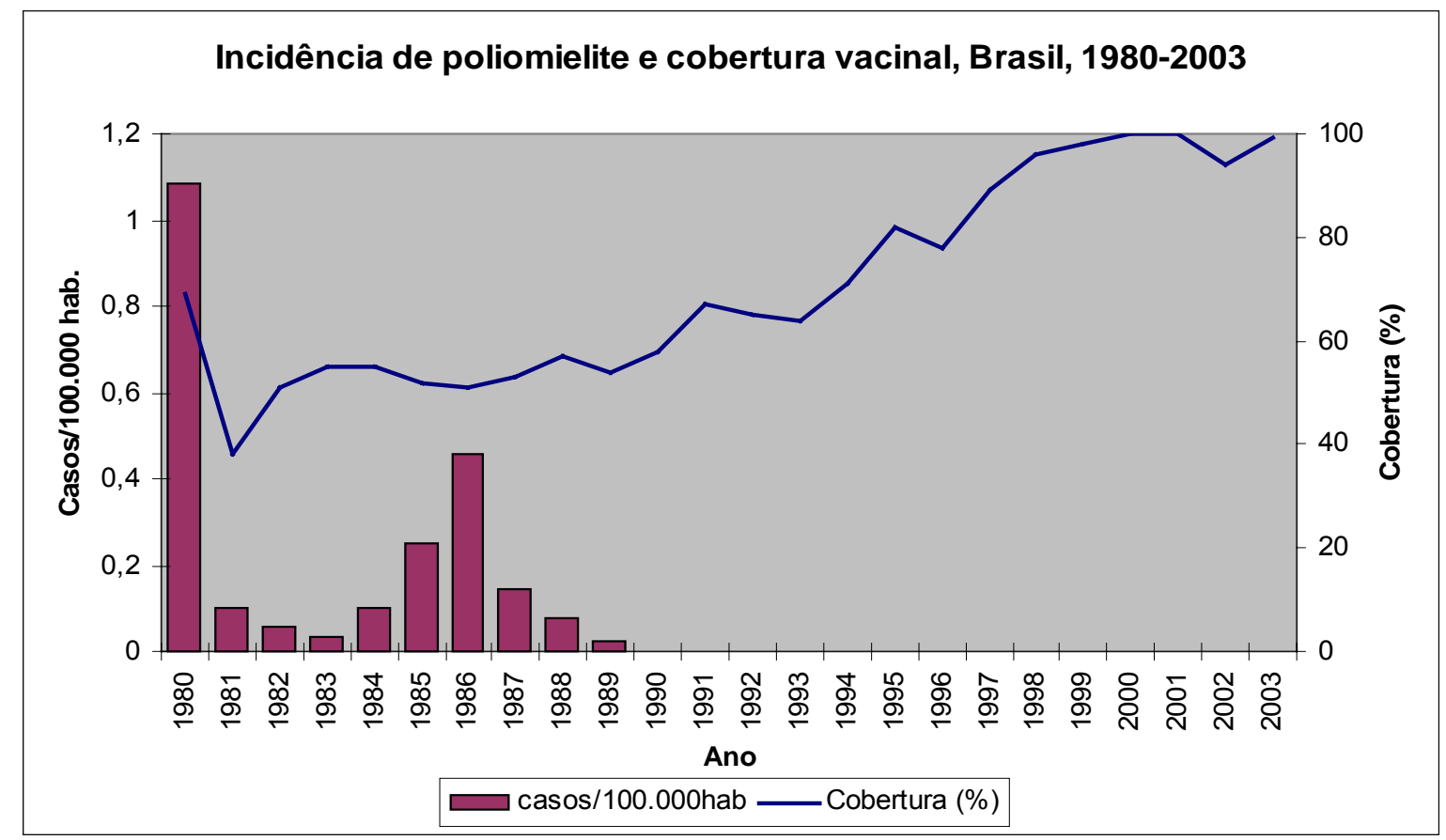

Fontes: SVS/MS, SES, SINAN, PNI, DEVEP e IBGE 
Gráfico 2

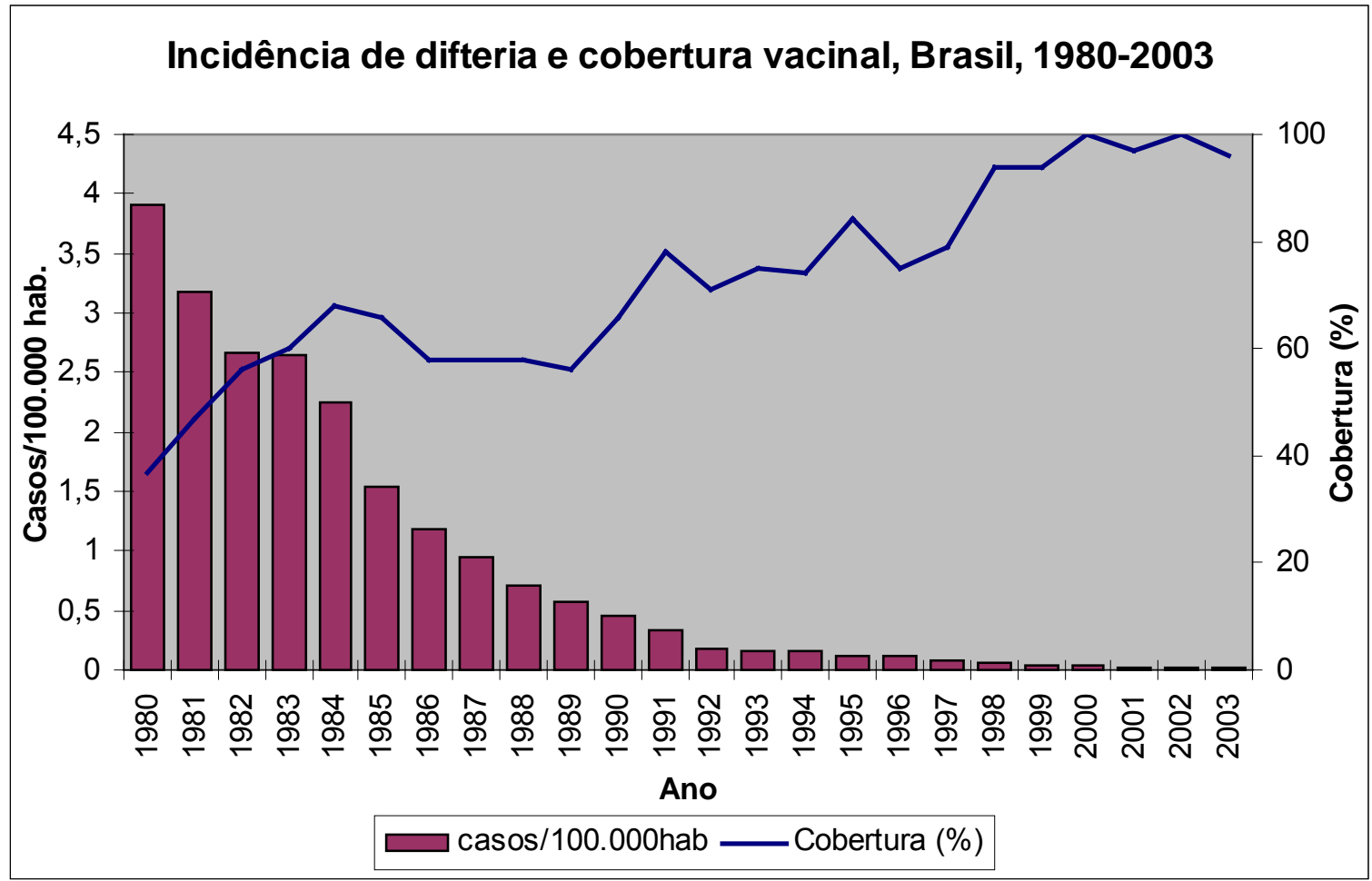

Fontes: SVS/MS, SES, SINAN, PNI, DEVEP e IBGE

Gráfico 3

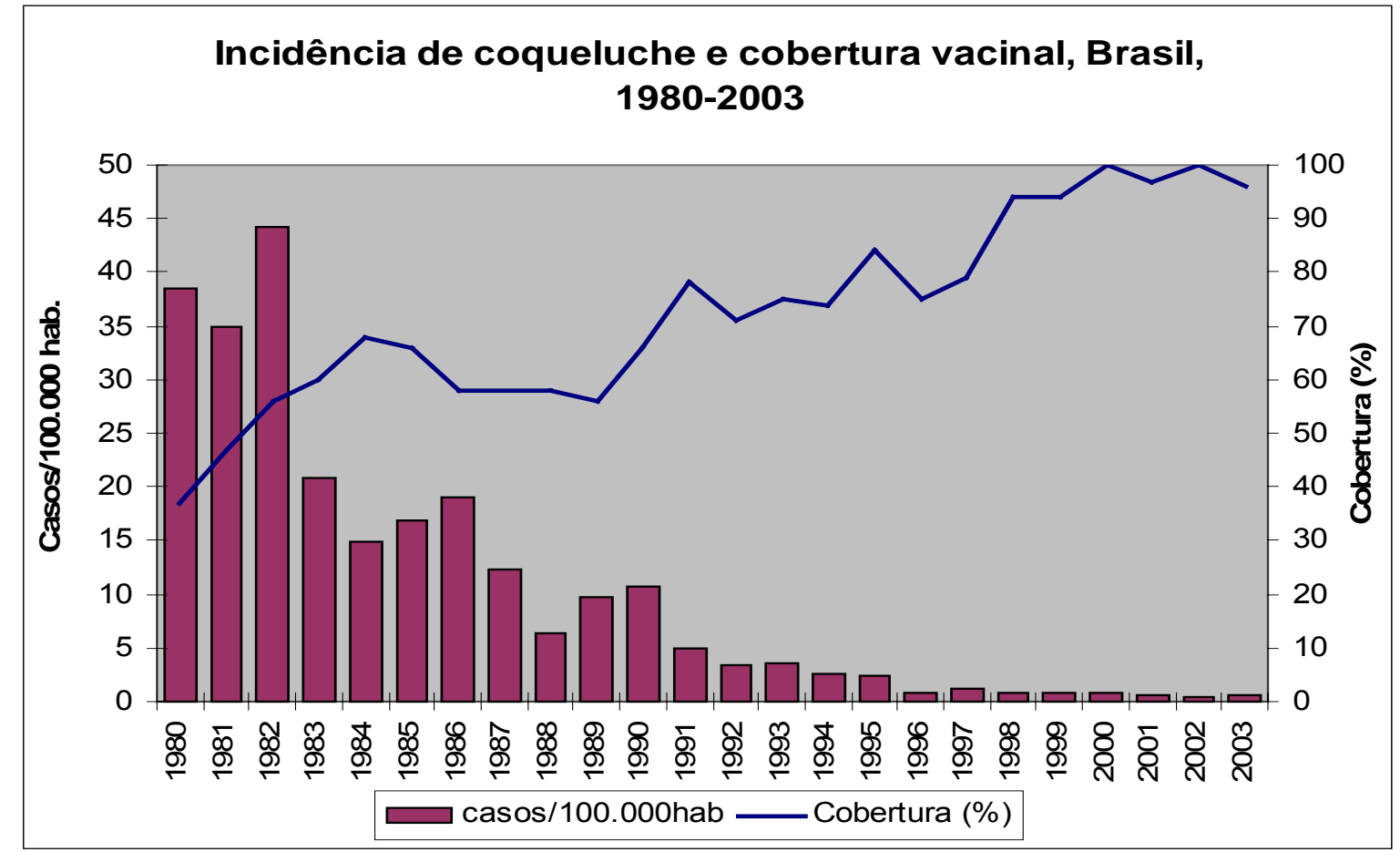

Fontes: SVS/MS, SES, SINAN, PNI, DEVEP e IBGE 
Gráfico 4

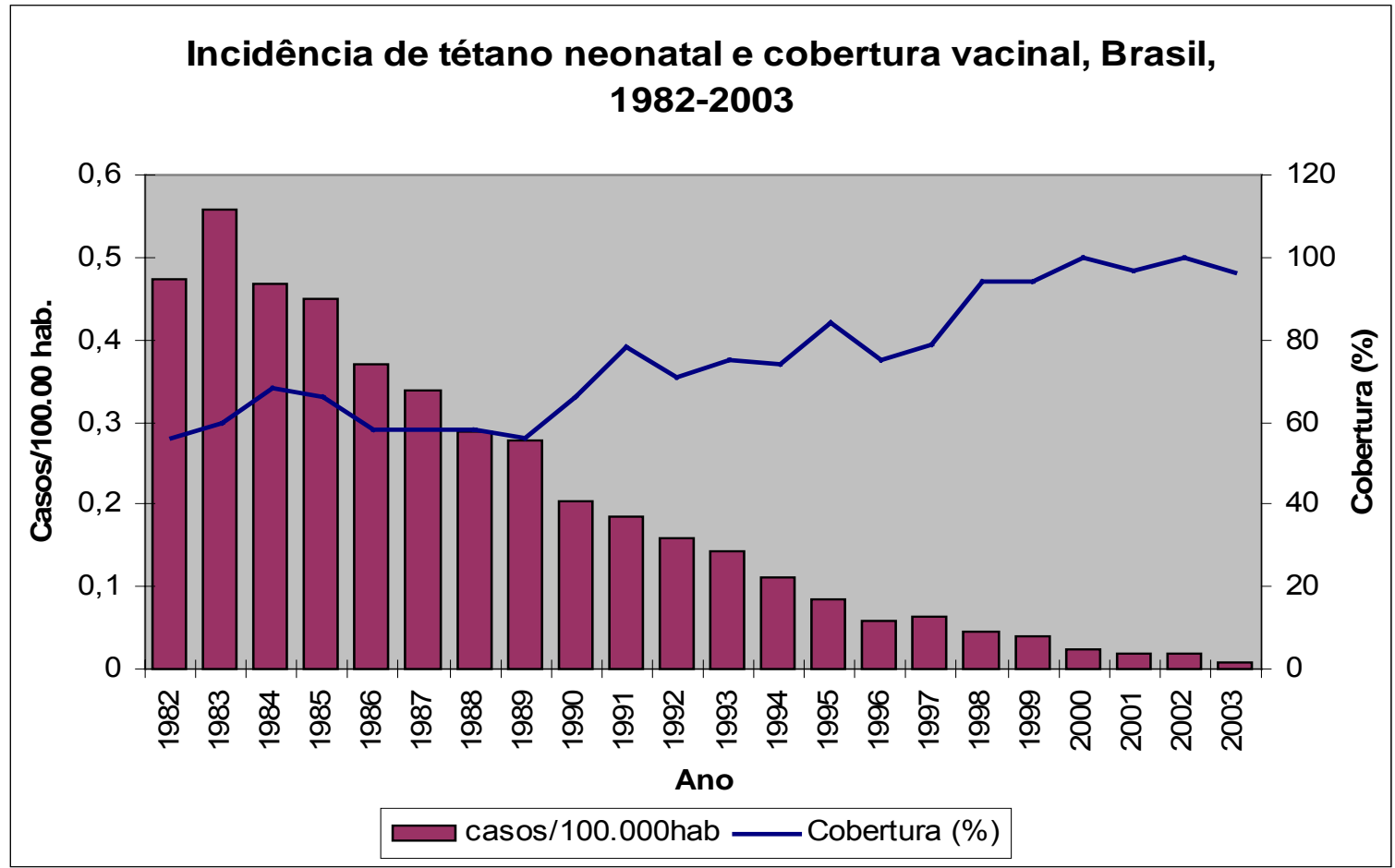

Fontes: SVS/MS, SES, SINAN, PNI, DEVEP e IBGE

Gráfico 5

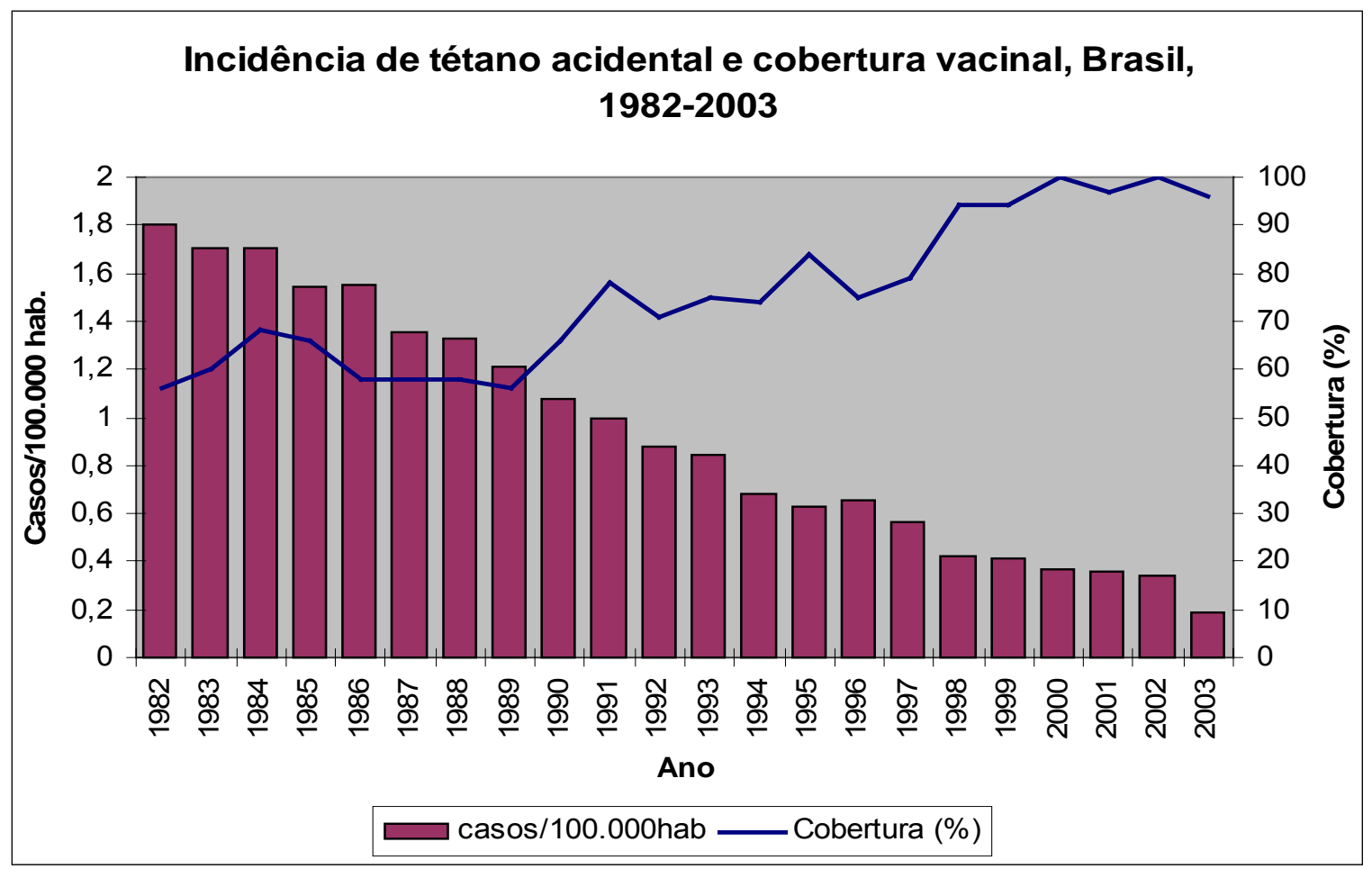

Fontes: SVS/MS, SES, SINAN, PNI, DEVEP e IBGE 
Gráfico 6

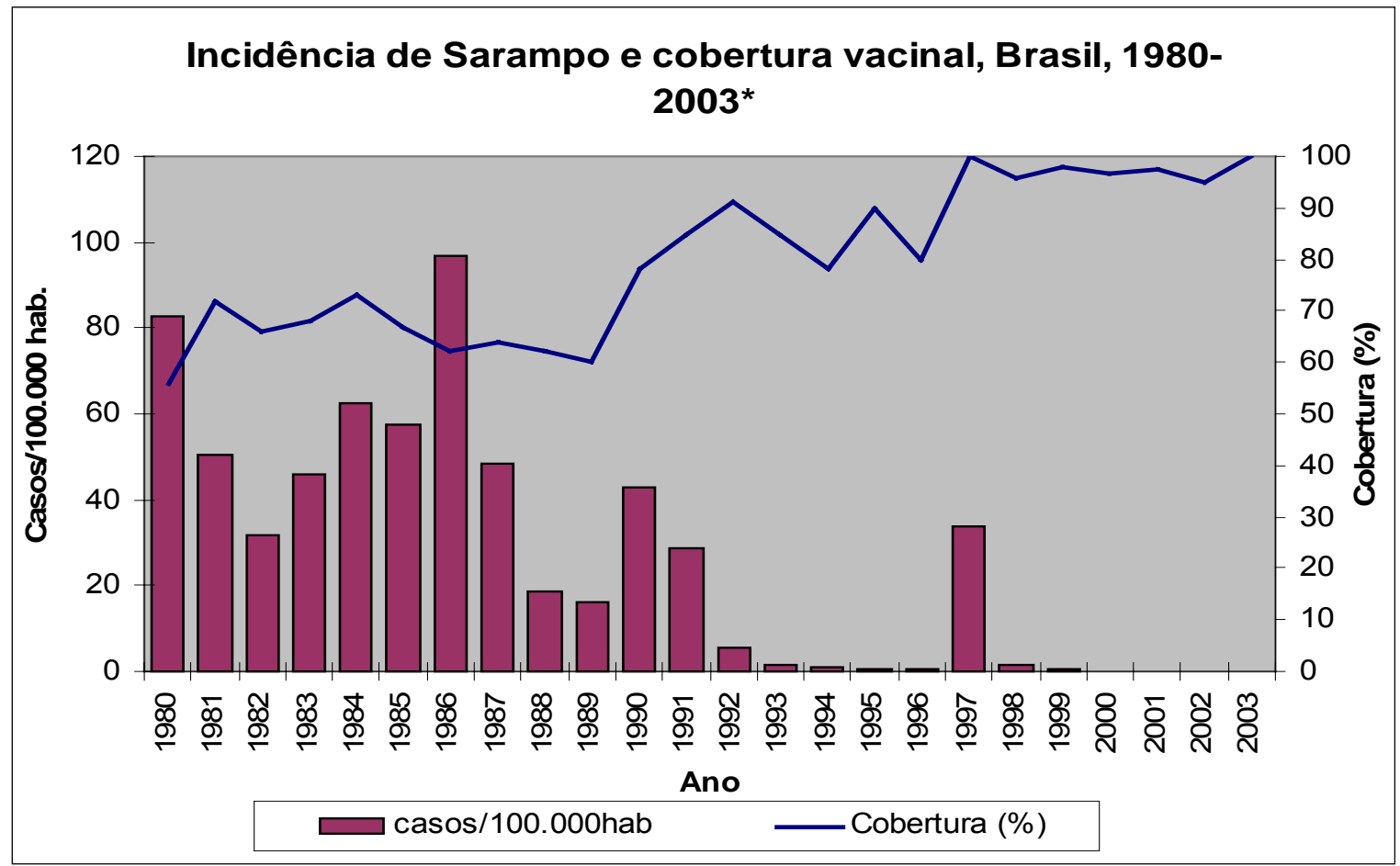

Fontes: SVS/MS, SES, SINAN, PNI, DEVEP e IBGE

* A partir de 2003, a cobertura vacinal considerada é a da vacina tríplice viral (Sarampo, Caxumba Rubéola)

\section{Gráfico 7}

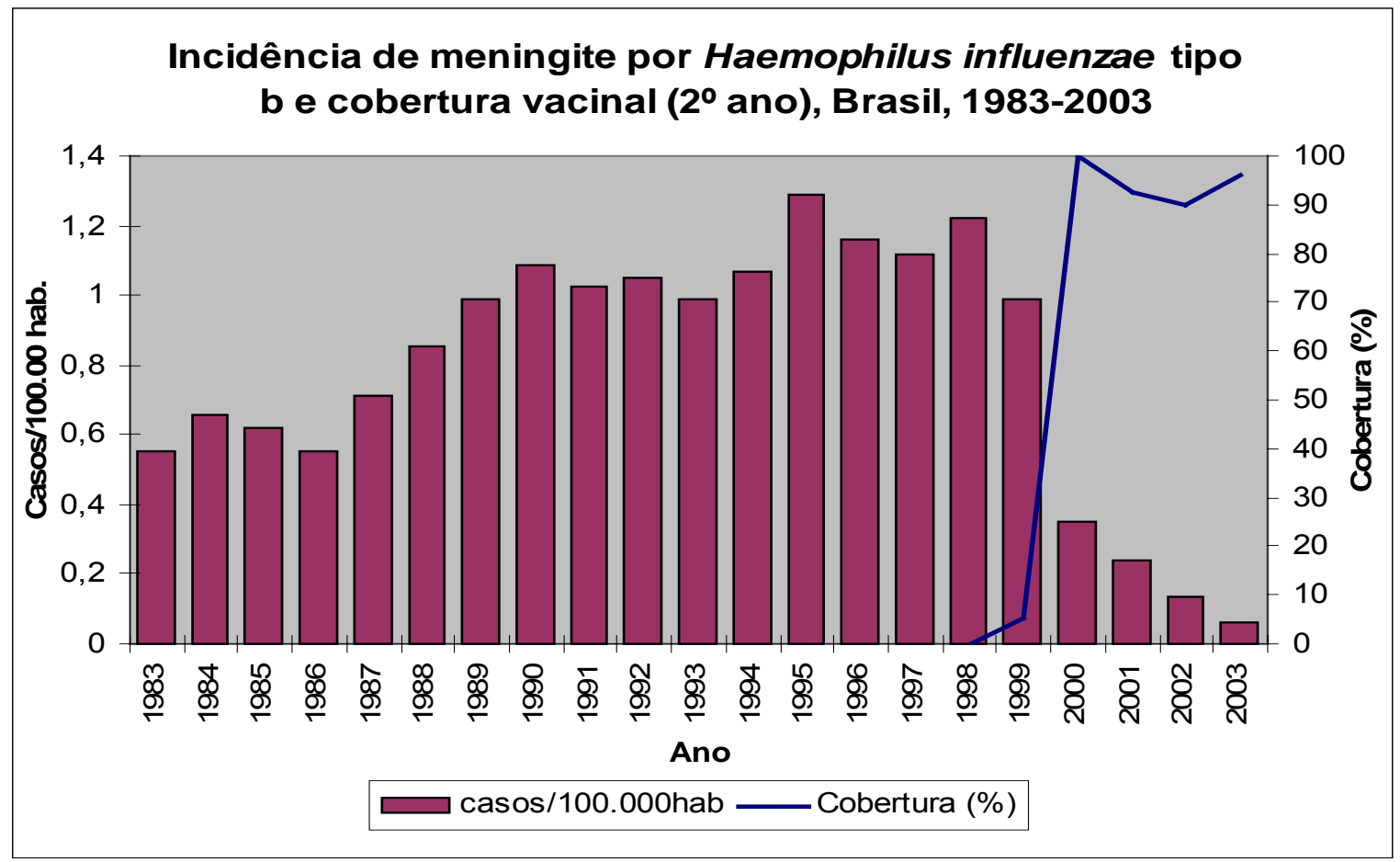

Fontes: SVS/MS, SES, SINAN, PNI, DEVEP e IBGE 
Ao lado destas extraordinárias conquistas, o desenvolvimento e a introdução de novas vacinas nos países em desenvolvimento ainda enfrentam muitos desafios. Eles incluem a necessidade de vacinas de baixo custo, combinadas, termo-estáveis, e de vacinas contra doenças que ocorrem predominantemente nestes países.

A ampliação do uso dos imunógenos envolve, também, a perspectiva de que os conhecimentos disponíveis devem estar ao alcance de todos os profissionais da saúde, para que os procedimentos de imunização sejam corretamente indicados para toda a população, incluindo-se não só a vacinação na infância como a de adultos em geral e, em particular, de idosos, de imunodeprimidos e de indivíduos com doenças de base que condicionem necessidade de imunização específica.

Estes motivos justificam a importância e a pertinência das considerações sobre a inserção de um centro de imunizações em hospital escola, em um país em desenvolvimento, que são apresentadas a seguir.

\section{O CENTRO DE IMUNIZAÇÕES DO HOSPITAL DAS CLÍNICAS DA FACULDADE DE MEDICINA DA UNIVERSIDADE DE SÃO PAULO}

A vacinação é uma medida de grande importância na prevenção e controle das doenças infecciosas, cuja operacionalização se efetiva por meio dos programas de vacinação.

O Programa Nacional de Imunizações (PNI) brasileiro sistematiza e coordena as ações de vacinação em todo o território nacional.

"O alcance dos objetivos do PNI e a adoção de estratégias com um mínimo de unidade exigem a articulação das instâncias centrais e locais, de forma a compatibilizar atividades, necessidades e realidades, num esforço conjunto"16.

O adequado armazenamento dos imunobiológicos, sua distribuição, a capacitação de recursos humanos envolvidos neste processo são fundamentais na instância local para assegurar o êxito do programa nacional. Neste contexto se insere o Centro de Imunizações do Hospital das Clínicas da Faculdade de Medicina da Universidade de São Paulo.

\section{1-HISTÓRICO}

A criação do $\mathrm{PNI}$, em 1973, refletia o interesse e a preocupação das autoridades de saúde pública em relação às doenças abrangidas pelo programa, e a crença nas medidas preventivas baseadas na vacinação.

O estudo das vacinas, e seus usos, já vinha despertando a atenção de alguns pioneiros neste assunto. No Brasil, e em particular no Estado de São 
Paulo, alguns médicos se destacaram, já desde o início dos anos de 1970, em relação ao estudo das vacinas e suas aplicações. Trabalhando tanto na saúde pública quanto na privada, destacam-se os nomes de Vicente Amato Neto, Gabriel W. Oselka, João Silva de Mendonça, Calil Kairalla Farhat. Decorrente deste contexto, instalação e consolidação do PNI e interesse pelo assunto vacinação, o Professor Vicente Amato Neto, que ganhou o concurso para professor titular do Departamento de Medicina Tropical e Dermatologia em 1976, cria o Centro de Imunizações do Hospital das Clínicas em 1981, conforme consta do Processo $\mathrm{n}^{\circ}$ 02885/81, do Departamento de Administração da Secretaria de Estado da Saúde de São Paulo:

"Protocolo de Cooperação Mútua que entre si celebram a Secretaria da Saúde e o Hospital das Clínicas da Faculdade de Medicina da USP, visando ao desenvolvimento conjunto de pesquisas e atividades no campo de imunizações".

"Aos 29 dias do mês de outubro do ano de mil novecentos e oitenta e um, na sede da Secretaria de Estado da Saúde, entre partes, de um lado a referida Secretaria, neste ato representada pelo seu Titular, Professor Doutor Adib Domingos Jatene, e, de outro, o Hospital das Clínicas da Faculdade de Medicina da USP, representado pelo seu Superintendente, Professor Doutor Primo Curti, consoante autorização do Senhor Governador do Estado, às folhas 34 do Processo $n^{\circ}$ 02885/81, considerando seus objetivos e atribuições e a necessidade de realização de atividades que possibilitem o esclarecimento de questões relacionadas com Imunizações e o desenvolvimento de novos conhecimentos neste campo, celebram o presente Protocolo de Cooperação Mútua".

Este centro de imunização, instalado em hospital escola, diferia das salas de vacinas da rede pública, uma vez que, além da parte assistencial, tinha especial preocupação com o ensino e a pesquisa no campo das imunizações. Mesmo assim, há de se notar o aparente paradoxo da instalação de um serviço de atenção primária em um hospital escola de grande porte, de nível de atendimento terciário. Aparente paradoxo que se justificava na época pela inovação que representava a preocupação com o estudo do uso das vacinas na área da saúde pública.

Posteriormente, em 1988, o Manual de Norma de Imunizações, em sua parte inicial, traz a recomendação de vacinação de pacientes internados, ou no momento da alta, como estratégia importante para atualizar esquemas e mesmo evitar transmissão intra-hospitalar.

Outro ponto a se destacar é o local de instalação do Centro de Imunizações do Hospital das Clínicas. Situado no Prédio dos Ambulatórios (PAMB) do Hospital das Clínicas $(\mathrm{HC})$, no piso de entrada ( $4^{\circ}$ andar), próximo à porta da entrada principal (bloco 8), local por onde circulam obrigatoriamente todos os usuários do hospital, constituídos principalmente por adultos. Vacinação era, e ainda é de certo modo, objeto de interesse predominantemente de pediatras. Entretanto, o envolvimento do Professor Amato, médico de doenças infecciosas e parasitárias de adulto, com o tema vacinação foi determinante para que o Centro de Imunizações fosse criado, fazendo parte da Divisão de Clínica de Moléstias Infecciosas e Parasitárias do Hospital das Clínicas da Faculdade de Medicina da 
Universidade de São Paulo (HCFMUSP), clínica esta caracteristicamente de atendimento de adultos.

Desde sua implantação em 1981, o Centro de Imunizações do Hospital das Clínicas sempre contou com a participação dos médicos da Divisão de Clínica de Moléstias Infecciosas e Parasitárias do HCFMUSP na condução de suas atividades, tendo como diretor o Professor Vicente Amato Neto, como médico responsável o Doutor Joel Tedesco e como enfermeira responsável a Senhora Rosa Maria Martins Andreoli. A partir de 1991, passo a ser a médica responsável pelo Centro de Imunizações do HCFMUSP, contando, posteriormente, com a colaboração de duas médicas assistentes, Doutora Ana Marli Christovan Sartori e Doutora Fátima Mitiko Tengan, persistindo a enfermeira Rosa Maria Martins Andreoli. Em 1991, quando assumi o Centro de Imunizações do Hospital das Clínicas, iniciei o trabalho de reconhecimento e valorização deste serviço, ampliando e treinando seu corpo de funcionários, implementando as atividades assistenciais e de ensino, e estabelecendo atividades de pesquisa.

Em relatório de atividades elaborado em 1985, o Doutor Joel Tedesco ${ }^{*}$ lista os objetivos do Centro de Imunizações do HC:

- Prestar serviço assistencial no campo das imunizações ativas e passivas.

- Promover e dar assistência a trabalhos de pesquisa científica.

- Padronizar normas de procedimento no complexo do Hospital das Clínicas.

- Manter intercâmbio com Postos de Saúde dando cobertura técnica e apoio aos casos de complicações vacinais mais graves.

- Promover atividades didáticas e científicas através de reuniões permanentes e periódicas versando sobre temas pertinentes.

- Organizar o Curso Básico de Imunizações, realizado anualmente.

Em decorrência do êxito do PNI, passou a aumentar a demanda por outros imunógenos. Neste mesmo relatório de 1985 consta o número total de doses de imunobiológicos aplicadas: 13.128 , das quais 10.217 correspondiam à vacina contra o tétano e apenas 52 à vacina contra hepatite B. Já em 1991, das 11.661 doses aplicadas, 1323 correspondiam às de vacina contra hepatite $B$.

Aumentava a solicitação também por indicações mais amplas, que abrangessem diversos segmentos da população, tais como pacientes imunodeprimidos, tanto crianças como adultos. O Centro de Imunizações do HCFMUSP já oferecia, aos funcionários e pacientes do Complexo $\mathrm{HC}$, não só os imunobiológicos que faziam parte do esquema de vacinação básica, como também alguns imunógenos especiais, não disponíveis rotineiramente nos postos de imunização públicos, tais como: a vacina anti-pneumocóccica polissacarídea 23 valente, a vacina contra hepatite $B$, as imunoglobulinas humanas hipenimunes contra tétano e contra hepatite B e a imunoglobulina humana comum**t Estes imunobiológicos eram, em parte, fornecidos pela Secretaria de Estado da Saúde de São Paulo e, em outra parte, comprados pelo próprio Hospital das Clínicas.

\footnotetext{
${ }^{*}$ Centro de Imunizações do HCFMUSP - Relatório de Atividades de 1985 (Documento interno).

** Centro de Imunizações do HCFMUSP - Avaliação das Atividades Desenvolvidas no Centro de Imunizações do HCFMUSP de 1991 a 1995 (Documento interno).
} 
As autoridades de saúde pública estavam sensíveis a este aumento de demanda por novos imunobiológicos. Em maio de 1987, havia sido criada a Comissão Permanente de Assessoramento em Imunizações da Secretaria de Estado da Saúde de São Paulo, sob a presidência do médico pediatra Gabriel W. Oselka, com a finalidade de dar suporte científico às ações de imunização no Estado de São Paulo. Desde 1989, esta Comissão e o Centro de Vigilância Epidemiológica "Professor Alexandre Vranjac" da Secretaria de Estado da Saúde de São Paulo vinham propondo a implantação de Centro de Referência em Imunobiológicos Especiais visando atender aos pacientes que necessitavam de imunobiológicos não disponíveis na rede pública ${ }^{2}$.

Atenta a estes anseios, e acreditando na importância deste empreendimento, envidei todos meus esforços para que este Programa fosse instalado no Centro de Imunizações do Hospital das Clínicas da FMUSP.

Em 17 de março de 1992 é assinado, pelo Senhor Secretário de Estado da Saúde de São Paulo, Professor Nader Wafae, e pelo Superintendente do Hospital das Clínicas da FMUSP, Professor Vicente Amato Neto, Termo de Cooperação Técnica que tem por objetivo:

1. colocar à disposição da população alguns produtos imunobiológicos considerados especiais, que não fazem parte do Programa Nacional de Imunizações; e

2. realizar pesquisas técnico-científicas na área de imunização.

A cláusula segunda deste Termo de Cooperação Técnica diz, no parágrafo I, que compete ao Hospital: promover a implantação e manutenção do Centro de Imunizações do Hospital que deverá ser centro regional de referência e treinamento em imunobiológicos considerados especiais.

O parágrafo II reza que compete ao Centro de Imunizações:

3. (...)formar e reciclar recursos humanos em imunização.

4. elaborar pesquisas em imunizações. $(\ldots)^{26}$.

Este programa, entretanto, só vem a ser viabilizado no segundo semestre de 1993, quando são implantadas as primeiras unidades de Centros de Referência em Imunobiológicos Especiais (CRIEs) do país. A proposta inicial de localizar os CRIEs em centros que concentravam a demanda de pacientes, vinculava também estes hospitais ou ambulatórios ao ensino das práticas de imunização, considerado prioritário na formação médica.

Assim é que o Centro de Imunizações do HCFMUSP passa a ser, a partir de 09 de dezembro de 1993, sob minha coordenação, Centro de Referência em Imunobiológicos Especiais para a região da Grande São Paulo, funcionando 24 horas ininterruptamente, como piloto desse programa, no Estado de São Paulo*. A dispensação dos imunógenos obedecia normas estabelecidas no Manual dos Centros de Referência para Imunobiológicos Especiais ${ }^{27}$.

Ficava assim consolidada a inserção do Centro de Imunizações em um hospital de ensino, de alta complexidade, uma vez que passava a ser centro de

\footnotetext{
* Centro de Referência para Imunobiológicos Especiais (CRIE) do HCFMUSP. Relatório do primeiro ano de funcionamento do CRIE do HCFMUSP. São Paulo. Dezembro de 1994.
} 
referência em imunobiológicos especiais para área de grande extensão, e deveria ser fonte de ensino e pesquisa.

\section{Os Centros de Referência em Imunobiológicos Especiais (CRIEs)}

Em 1993, são implantadas as primeiras unidades dos Centros de Referência para Imunobiológicos Especiais - os CRIEs, pelo Ministério da Saúde. A implantação é iniciada nos estados do Paraná, São Paulo, Ceará, no Distrito Federal e no estado do Pará ${ }^{17}$.

O objetivo do PNIt, nos últimos 30 anos, tem sido o "controle, eliminação e/ou erradicação das doenças imunopreveníveis, através de altas coberturas vacinais homogêneas e desenvolvimento de uma Política Nacional de AutoSuficiência, controle de qualidade dos imunobiológicos ofertados à população, implementação da rede de frio nos níveis local, estadual e nacional e qualificação de recursos humanos, além de um programa de suprimento de alguns imunobiológicos especiais, para grupos populacionais específicos".

"O suprimento dos imunobiológicos necessários, sem ônus para os órgãos executores, é de responsabilidade do nível federal, que adquire os produtos, coordena a importação e incentiva a produção nacional. A qualidade dos produtos distribuídos é garantida mediante atuação do Instituto Nacional de Controle de Qualidade em Saúde (INCQS), da estrutura da Fundação Oswaldo Cruz (FIOCRUZ), criado em 1981. Amostras de todos os lotes dos imunobiológicos, nacionais ou importados, são analisadas pelo INCQS antes da distribuição para consumo. O Instituto é referência técnica para os laboratórios produtores" ${ }^{16}$.

$\mathrm{Na}$ introdução da primeira edição do manual "Norma para os Centros de Referência para Imunobiológicos Especiais", está escrito que a limitação das indicações, daí o nome especiais, deve-se fundamentalmente a razões de ordem econômica ${ }^{27}$.

No decorrer dos últimos 10 anos, instruções normativas suplementares, publicadas no Diário Oficial da União, foram redigidas para regulamentar o funcionamento dos CRIEs:

- Instrução Normativa $n^{\circ}$ 2, de 24 de setembro de 2002.

- Instrução Normativa $n^{\circ}$ 2, de 30 de janeiro de 2003.

- Portaria $n^{\circ} 48$, de 28 de julho de 2004, da Secretaria de Vigilância em Saúde (SVS).

Atualmente, existem 37 CRIEs no Brasil. Destes, quatro estão localizados no Estado de São Paulo, sendo dois na capital, um em Campinas e um em Ribeirão Preto. Estes quatro CRIEs são ligados a hospitais universitários: Hospital das Clínicas da FMUSP, Universidade Federal de São Paulo (UNIFESP), Universidade Estadual de Campinas (UNICAMP) e Universidade de São Paulo (USP) campus de Ribeirão Preto. Estão em fase de implantação, no Estado de São Paulo, os CRIEs de Botucatu ( ligado à Faculdade de Medicina da UNESP) e de Santo André (ligado à Faculdade de Medicina do ABC).

\footnotetext{
* Ministério da Saúde do Brasil. Relatório do encontro nacional dos centros de referências para imunobiológicos especiais. Curitiba. Paraná. 15 a 17 de abril de 1998.
} 
Em 1996, o PNI, em conjunto com o Comitê Técnico Assessor em Imunizações, realizou supervisão em todos os CRIEs já instalados no Brasil, e detectou a necessidade de reunir todos os responsáveis por estes centros para discussão de procedimentos e reavaliação dos critérios de indicação dos imunobiológicos especiais. Durante os dias 13 e 14 de abril de 1998, foi realizado o Encontro Nacional dos Centros de Referência para Imunobiológicos Especiais em Curitiba, Paraná. A partir dos temas discutidos nesse encontro, foram ampliados os critérios de indicação dos imunobiológicos já existentes e introduzidos novos ${ }^{t}$ Estas resoluções levaram à elaboração da segunda edição do "Manual dos Centros de Referência de Imunobiológicos Especiais", publicada em $1999^{28}$.

Basicamente, as indicações de imunobiológicos especiais podem ser incluídas nos seguintes grupos ${ }^{29}$ :

a) Profilaxia pré e pós-exposição a agentes infecciosos, em determinadas situações de risco.

b) Substituição de outros produtos disponíveis normalmente, quando não podem ser utilizados devido a reações de hipersensibilidade ou eventos adversos.

c) Imunização de crianças ou adultos com imunocomprometimento.

No ano de 2004, a coordenação do PNI convidou alguns coordenadores de CRIEs e especialistas em vacinação, para revisarem o segundo manual de normas, e elaborarem a terceira edição, ainda não finalizada. Integram esta comissão:

- Gerson Zanetta de Lima - Coordenador. (CRIE Londrina, Paraná)

- Ernesto Renoiner (PNI)

- Jacy Andrade (CRIE Salvador, Bahia)

- Maria Ângela Rocha (CRIE Recife, Pernambuco)

- Marta Heloisa Lopes (CRIE HC SP São Paulo, São Paulo)

- Solange Andrade (CRIE Manaus, Amazonas)

- Supervisão: Professor Reinaldo Meneses Martins (Rio de Janeiro).

\footnotetext{
* Ministério da Saúde do Brasil. Relatório do encontro nacional dos centros de referências para imunobiológicos especiais. Curitiba. Paraná. 15 a 17 de abril de 1998.
} 


\section{ESTRUTURAÇÃO E DESENVOLVIMENTO DO CENTRO DE IMUNIZAÇÕES DO HOSPITAL DAS CLÍNICAS DA FACULDADE DE MEDICINA DA UNIVERSIDADE DE SÃO PAULO / CRIE HC SP}

\subsection{ESTRUTURA}

Composição atual do CRIE HC SP:

Médica responsável: Marta Heloisa Lopes (desde sua criação)

Médicas assistentes: Ana Marli Christovan Sartori (desde abril de 1994).

Cilmara Polido Garcia (a partir de 2004).

Médica comissionada: Melissa Mascheretti (a partir de fevereiro de 2002).

Enfermeira responsável: Rosa Maria Martins Andreoli (desde sua criação).

Técnica de enfermagem: Sara Rosa Silva

Auxiliares de enfermagem: Marina Zita do Nascimento / Carmen Silvia

Rodrigues Correa

Escriturária: Simone Cavalheiro Gregório

Porteiro: Ailton Almeida

O Centro de imunizações do HCFMUSP também já contou com importante participação das médicas Fátima Mitiko Tengan e Eliana Battaggia Gutierrez.

Chegar a esta equipe e grau de estruturação atual demandou um persistente trabalho de construção. Quando assumi a responsabilidade pelo Centro de Imunizações do HCFMUSP, não havia médicos escalados para cobertura das atividades assistenciais em todos os dias da semana. Havia uma só auxiliar de enfermagem, que, por ocasião das férias, era substituída por funcionários inexperientes em relação às atividades de vacinação. Entre o horário em que se encerrava o funcionamento de rotina do Centro de Imunizações (16:00h), e aquele em que se iniciava o plantão (20:00h) não havia cobertura médica, para dispensação de imunógenos de urgência. Do ponto de vista administrativo, não contávamos com funcionários lotados no Centro de Imunizações.

Cada uma destas lacunas foi sendo preenchida, após muita insistência e trabalho de convencimento da importância do serviço. Da Divisão de Clínica de Moléstias Infecciosas e Parasitárias conseguimos a designação de médicos, tanto para os atendimentos de rotina, quanto para a cobertura das 24 horas ininterruptamente, em regime de trabalho de pronto-atendimento. Da direção do HCFMUSP conseguimos os funcionários administrativos, escriturária e porteiro. Da Secretaria de Estado da Saúde de São Paulo recebemos uma técnica de enfermagem.

Atualmente, a equipe do CRIE HC SP presta serviços assistenciais, exerce atividades de ensino e procura desenvolver investigação científica. Cumpre dessa maneira as atividades de extensão universitária, ensino e pesquisa, propostas pela Universidade de São Paulo.

\subsection{DESENVOLVIMENTO}


Desde o início de seu funcionamento, ficou claro que o CRIE HC SP tinha peculiaridades decorrentes de sua localização em um hospital do porte do Hospital das Clínicas da FMUSP. O atendimento a transplantados de órgãos sólidos e de medula, raros ou inexistentes em outros centros, era rotineiro. A existência de associações de portadores de patologias gerava uma grande demanda, composta de pacientes esclarecidos e exigentes. Os médicos encaminhadores, em sua maioria especialistas, nem sempre concordavam com as regras estabelecidas para a dispensação de imunobiológicos.

Os imunobiológicos disponíveis no primeiro ano de funcionamento do CRIE HC SP eram:
Vacina inativada contra poliomielite (SALK)
Vacina conjugada contra o Haemophilus influenzae tipo b
Vacina polissacarídea contra Pneumococo 23 valente
Vacina contra raiva obtida em cultura de células
Vacina contra Hepatite B
Imunoglobulina humana hiperimune anti-rábica
Imunoglobulina humana hiperimune anti-Varicela-Zoster
Imunoglobulina humana hiperimune anti-tetânica
Imunoglobulina humana hiperimune anti-hepatite B.

Em relatório encaminhado à Divisão de Imunização da Secretaria de Estado da Saúde de São Paulot, cujos dados foram também apresentados no XXXI Congresso da Sociedade Brasileira de Medicina Tropical ${ }^{30}$, analisamos 0 atendimento dispensado aos 747 indivíduos atendidos no primeiro ano de funcionamento do CRIEHCSP (13/12/1993 a 13/12/1994). O número total de imunobiológicos especiais aplicados neste primeiro ano do novo Programa foi de 1417. Um dos objetivos prioritários dos CRIEs era a vacinação de crianças imunodeprimidas. Este objetivo foi alcançado, uma vez que, dos 747 indivíduos atendidos, $69 \%$ tinham até 18 anos de idade. Os esquemas vacinais empregados com mais freqüência foram aqueles contra infecções causadas pelo pneumococo e pelo Haemophilus influenzae tipo b, sendo que a condição de asplenia anatômica ou funcional contribuiu para aproximadamente $47 \%$ das indicações. Estes números provavelmente refletiam a organização dos serviços hematológicos infantis, que foram os principais responsáveis por estes encaminhamentos. Do total dos 747 indivíduos atendidos no primeiro ano de funcionamento do CRIE, $457(61,2 \%)$ eram provenientes do complexo HCFMUSP. Interpretamos estes dados como decorrentes de um programa em fase de implantação, cuja divulgação é mais fácil e eficiente para os serviços localizados junto ou mais próximos ao pólo irradiador. Esta demanda predominante do HCFMUSP, entretanto, nos parecia ser, em parte, compensada pelo fato de, no complexo, serem atendidos pacientes provenientes de vários bairros da cidade, do interior do Estado de São Paulo e até de outros estados do Brasil. Os encaminhamentos não provenientes do complexo HC totalizaram 275 casos $(36,8 \%)$, dos quais 219

\footnotetext{
* Centro de Referência para Imunobiológicos Especiais (CRIE) do HCFMUSP. Relatório do primeiro ano de funcionamento do CRIE do HCFMUSP. São Paulo. Dezembro de 1994.
} 
(79,6\%) procedentes da cidade de São Paulo e 56 (20,4\%) procedentes de outras localidades, predominantemente do Estado de São Paulo.

Chamou a atenção da equipe do CRIE o encaminhamento sistemático e organizado de transplantados e candidatos a transplante de órgãos, predominantemente do Serviço de Transplante de Medula Óssea (TMO) do HCFMUSP. Tal realidade foi motivo de discussões entre a equipe do CRIE HC SP e os integrantes da Comissão Permanente de Assessoramento em Imunizações da Secretaria de Estado da Saúde de São Paulo, que resultaram em norma específica para distribuição dos imunógenos especiais a transplantados, particularmente os de medula óssea. A elaboração dos esquemas vacinais inicialmente contou com a colaboração da doutora Clarisse Martins Machado.

A divulgação da experiência acumulada nas atividades de trabalho sempre fez parte de nossas prioridades. Para que isso pudesse ocorrer de modo mais efetivo, era conveniente que tivéssemos um banco de dados informatizado. Durante o ano de 1994, em parceria com o Serviço de Informática do Hospital das Clínicas, foi desenvolvido, por nossa solicitação e sob supervisão do Dr. Antonio Onofre Lira, programa de informatização do cadastro dos pacientes, das vacinas e doses administradas, com agendamento automático de retornos. A partir de outubro de 1994, o CRIE HC SP estava informatizado, ligado à rede de grande porte do Complexo HC - Sistema Main-Frame.

A maior agilidade no atendimento, proporcionada pelo cadastro eletrônico do paciente, possibilitou a ampliação dos programas de vacinação oferecidos.

Em 1996 ${ }^{31}$, além do Programa de Imunobiológicos Especiais, havíamos implantado e estavam ativos, no Centro de Imunizações do HCFMUSP, os seguintes programast.

- Vacinação de crianças matriculadas na creche do HCFMUSP, incluindo as vacinas de rotina e mais vacina contra hepatite B e vacina conjugada contra $H$. influenzae tipo b (compradas, por nossa solicitação, pelo Hospital das Clínicas da FMUSP, com seus próprios recursos financeiros) ${ }^{31}$. Posteriormente, respectivamente no segundo semestre de 1998 e no segundo semestre de 1999 , as vacinas contra hepatite $B$ e contra $H$. influenzae tipo b foram incluídas no calendário de rotina do PNI.

- Vacinação de adultos contra tétano e difteria, prioritariamente para os usuários do Complexo HCFMUSP.

- Vacinação contra tétano e difteria, hepatite B e rubéola ou sarampo / caxumba I rubéola, conforme a disponibilidade, para funcionários, aprimorandos e estagiários do Complexo HCFMUSP, alunos de graduação das Faculdades de Medicina e Enfermagem da USP e alunos de Pós Graduação (lato sensu) da FMUSP.

- Vacinação contra difteria e tétano para gestantes em acompanhamento pré-natal no HCFMUSP.

- Atendimento a pacientes da Unidade de Queimados (longa permanência) para atualização do esquema vacinal.

\footnotetext{
* Centro de Imunizações do Hospital das Clínicas da Faculdade de Medicina da Universidade de São Paulo. Relatório de Atividades. 1996 a 1998. (Documento interno).
} 
- Vacinação contra hepatite B para pacientes nefropatas, submetidos a procedimentos de diálise, encaminhados pela Secretaria de Estado da Saúde de São Paulo.

- Vacinação contra febre amarela para pessoas que se dirigem às regiões de risco de aquisição de infecção pelo vírus da febre amarela.

- Profilaxia pós-exposição para raiva em casos de acidentes, e profilaxia préexposição para indivíduos com possibilidade de exposição ao vírus em atividades profissionais.

- Vacinação com BCG intradérmica para comunicantes de hanseníase.

- Vacinação para recém-nascidos de longa permanência no Berçário do Hospital das Clínicas.

- Vacinação contra influenza, pneumococo e difteria e tétano, para pacientes do Serviço de Geriatria do Hospital das Clínicas da FMUSP e funcionários, inclusive aposentados, com 60 ou mais anos de idade (ainda não distribuídas sob a forma de campanha).

De modo pioneiro, antes da vacinação contra influenza ficar disponível na rede pública municipal, estadual ou federal, já estávamos vacinando, no Centro de Imunizações do HC, pacientes e funcionários a partir de 60 anos. Cabe salientar que esta iniciativa só pode se concretizar graças à compreensão da Superintendência do Hospital das Clínicas da FMUSP, que viabilizou a compra das vacinas.

Deve-se ressaltar também a criatividade e o empenho da equipe do Centro de Imunizações do $\mathrm{HC}$, na busca de oportunidades de vacinação. Foi assim que se iniciaram e persistem até os dias de hoje os programas de vacinação no Berçário e no Serviço de Queimados. Observou-se que, nestes locais, devido à longa permanência dos pacientes, era freqüente o retardo do início da vacinação ou, no caso dos pacientes queimados, o atraso em relação particularmente à segunda dose da vacina contra difteria e tétano, uma vez que, muitas vezes, a vacina administrada no momento do atendimento inicial era a primeira que o paciente havia recebido em sua vida.

No início do ano de 2000 , era evidente o crescimento quantitativo e qualitativo do Centro de Imunizações do $\mathrm{HC}$, e as seguintes metas tinham sido atingidas:

- Manutenção de todos os programas vigentes anteriormente

- Ampliação do programa de vacinação de idosos

- Reformulação do programa de vacinação de alunos da FMUSP.

- Acréscimo das vacinas contra hepatite A e contra varicela ao programa de vacinação das crianças da creche do $\mathrm{HC}$.

- Ampliação do programa de vacinação dos funcionários do $\mathrm{HC}$, com introdução das vacinas contra hepatite B e tríplice viral (sarampo, caxumba e rubéola) no momento de admissão do funcionário, além da vacina contra difteria e tétano. Posteriormente, a vacina contra varicela também foi incluída.

- Atualização do Manual do Centro de Imunizações.

- Implantação do "Programa de profilaxia após acidente com material biológico", desde 1998. 
Também em 1998, por desativação do sistema de grande porte, novo sistema eletrônico de cadastro e registro de produção foi introduzido no Centro de Imunizações do HC. A partir de 2004, o sistema de informatização do Centro de Imunizações do HC é mais uma vez modificado, para se adequar ao Sistema de Informações dos Centros de Referência para Imunobiológicos Especiais (SI CRIE). Estas contínuas mudanças no sistema de cadastro levaram, lamentavelmente, à perda de registros de algumas das vacinas dispensadas nos anos de 1996 e 1997. De qualquer modo, fica evidente, na tabela 4, o grande aumento de demanda observado nos últimos anos, que pode ser explicado tanto pela maior divulgação dos serviços oferecidos pelo CRIE HC SP, e conseqüente maior encaminhamento de pacientes (gráficos 8,9 e 10), quanto pela inclusão de novos imunógenos especiais (gráficos 11, 12 e 13). 
Tabela 4- Número de imunógenos dispensados no Centro de Imunizações do HCFMUSP de 1991 a 2004.

\begin{tabular}{|c|c|c|c|c|c|c|c|c|c|c|c|c|}
\hline Imunógeno $\backslash$ Ano & 1991 & 1992 & 1993 & 1994 & 1995 & 1998 & 1999 & 2000 & 2001 & 2002 & 2003 & 2004 \\
\hline BCG & 32 & 61 & 65 & 45 & 51 & 28 & 38 & 34 & 39 & 41 & 52 & 56 \\
\hline OPV (Sabin) & 253 & 248 & 221 & 188 & 211 & 286 & 222 & 233 & 214 & 246 & 270 & 391 \\
\hline IPV (Salk) & & & 1 & 141 & 61 & 0 & 142 & 145 & 179 & 297 & 370 & 402 \\
\hline DPT & 272 & 251 & 222 & 207 & 241 & 319 & 246 & 215 & 213 & 179 & 121 & 131 \\
\hline DPT acelular & & & & & & & & 27 & 83 & 102 & 98 & 190 \\
\hline Tetravalente & & & & & & & & & & 86 & 82 & 64 \\
\hline Pentavalente & & & & & & & & & & 2 & 97 & 110 \\
\hline DT & & & 3 & 12 & 1 & 9 & 3 & 5 & 11 & 11 & 26 & 19 \\
\hline Dt & 8896 & 8886 & 7291 & 7754 & 5169 & 6093 & 6265 & 7274 & 7429 & 6983 & 6892 & 6622 \\
\hline Sarampo & 75 & 77 & 65 & 55 & 49 & 139 & 69 & 56 & 74 & 71 & 1 & 0 \\
\hline Caxumba & 67 & 43 & 36 & 4 & 1 & 0 & 0 & 0 & 0 & 0 & 0 & 0 \\
\hline Rubéola & 104 & 248 & 40 & 16 & 69 & 0 & 0 & 55 & 0 & 0 & 0 & 0 \\
\hline SCR & 205 & 96 & 88 & 161 & 59 & 483 & 390 & 826 & 808 & 675 & 631 & 1542 \\
\hline SR & & & & & & & & 32 & 2985 & 22 & 7 & 5 \\
\hline $\mathrm{HIb}$ & & & 3 & 775 & 530 & 372 & 972 & 370 & 353 & 215 & 243 & 278 \\
\hline Febre amarela & 280 & 452 & 336 & 466 & 444 & 519 & 508 & 2470 & 1534 & 1694 & 2462 & 2732 \\
\hline Influenza & 28 & 0 & 0 & 0 & 0 & 865 & 1760 & 3728 & 4146 & 4627 & 6701 & 6316 \\
\hline Pneumo23 & 13 & 108 & 80 & 668 & 518 & 584 & 1309 & 1298 & 1192 & 1575 & 1559 & 2150 \\
\hline Raiva & 82 & 27 & 34 & 85 & 8 & 26 & 56 & 0 & 0 & 0 & 0 & 0 \\
\hline Raiva cult. Cel. & & & & 56 & 34 & 0 & 0 & 88 & 52 & 84 & 113 & 125 \\
\hline Ig anti-hepatite B & 25 & 14 & 19 & 58 & 38 & 75 & 238 & 548 & 393 & 263 & 332 & 343 \\
\hline Ig anti-varicela & & & & 28 & 7 & 0 & 221 & 115 & 111 & 192 & 384 & 171 \\
\hline lg antitetânica & 6 & 21 & 15 & 20 & 43 & 27 & 14 & 30 & 35 & 69 & 53 & 80 \\
\hline Ig anti-rábica & & & & 2 & 6 & 5 & 2 & 10 & 10 & 9 & 7 & 7 \\
\hline Varicela & & & & & & & 0 & 244 & 640 & 404 & 616 & 593 \\
\hline Hepatite A & & & & & & & & 111 & 397 & 769 & 808 & 861 \\
\hline Meningo C conj. & & & & & & & & & & 51 & 698 & 857 \\
\hline Pneumo7V conj. & & & & & & & & & & 17 & 676 & 1129 \\
\hline Febre Tifóide & & & & & & & & & & 9 & 179 & 138 \\
\hline
\end{tabular}




\author{
Legenda da Tabela 4: \\ BCG - Vacina contra tuberculose \\ OPV (Sabin) - Vacina oral de poliovirus vivos \\ IPV (Salk) - Vacina injetável de poliovirus inativados \\ DPT - Vacina contra difteria, coqueluche (células inteiras) e tétano \\ DPT acelular - Vacina difteria, coqueluche acelular e tétano \\ Tetravalente - Vacina contra difteria, coqueluche, tétano e $H$. influenzae tipo b \\ Pentavalente - Vacina contra difteria, coqueluche, tétano, $H$. influenzae tipo b e \\ hepatite B \\ DT - Vacina contra difteria e tétano (infantil) \\ dT - Vacina contra difteria e tétano (adulto) \\ SCR - Vacina contra sarampo, caxumba e rubéola \\ SR - Vacina contra sarampo e rubéola \\ HIb - Vacina contra $H$. influenzae do tipo b \\ Pneumo23 - Vacina anti pneumocócica de 23 polissacarídeos capsulares \\ Raiva cult. Cel. - Vacina contra raiva obtida em cultivo celular \\ Ig anti-hepatite B - Imunoglobulina hiperimune contra hepatite B \\ Ig anti-varicela - Imunoglobulina hiperimune contra varicela \\ Ig antitetânica - Imunoglobulina hiperimune contra tétano \\ Ig anti-rábica - Imunoglobulina hiperimune contra raiva \\ Meningo $C$ conj. - Vacina contra meningococo $C$, conjugada a proteína \\ Pneumo7V conj. - Vacina anti pneumocócica de 7 polissacarídeos capsulares, \\ conjugados a proteína
}


Gráfico 8

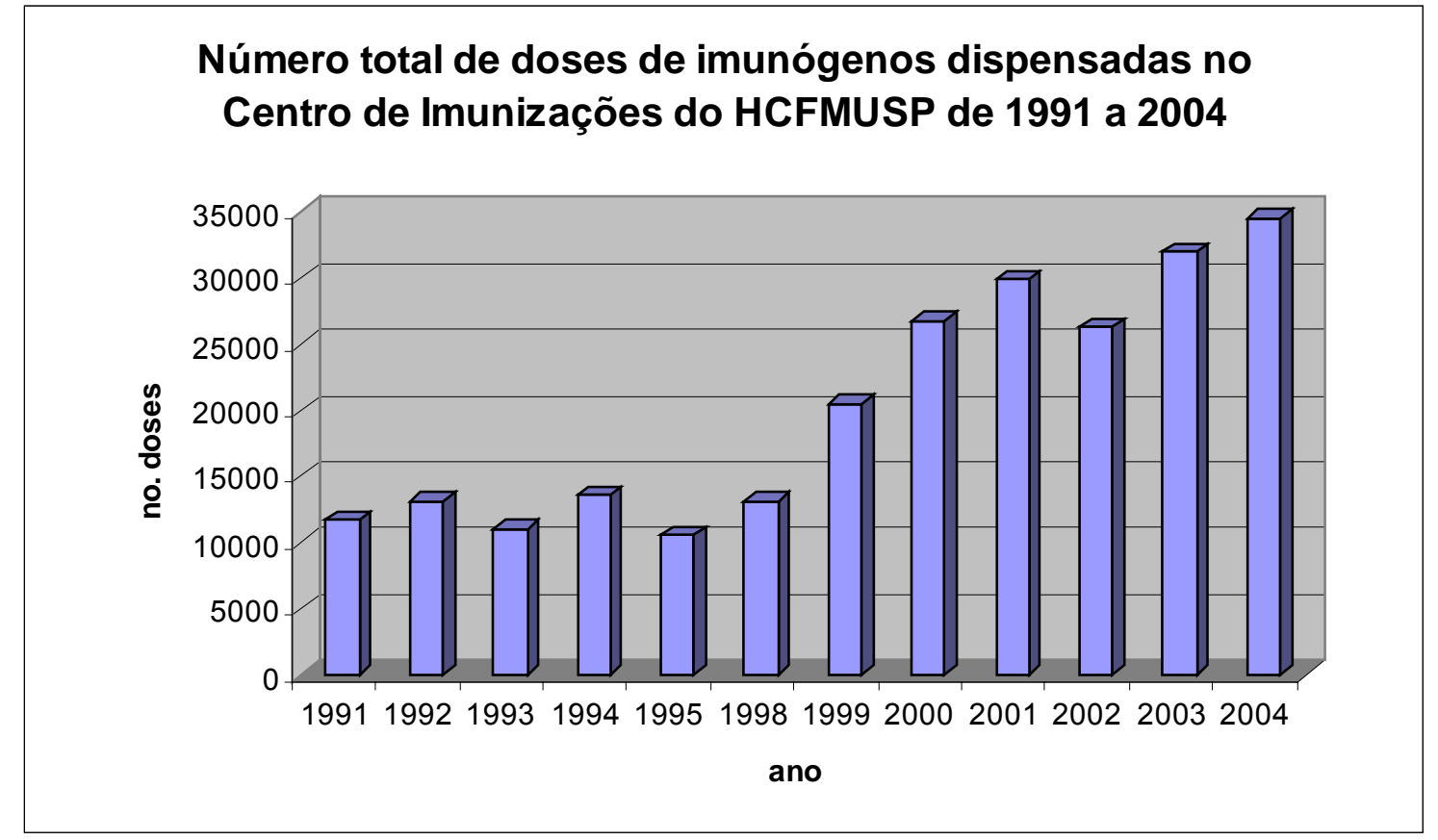

\section{Gráfico 9}

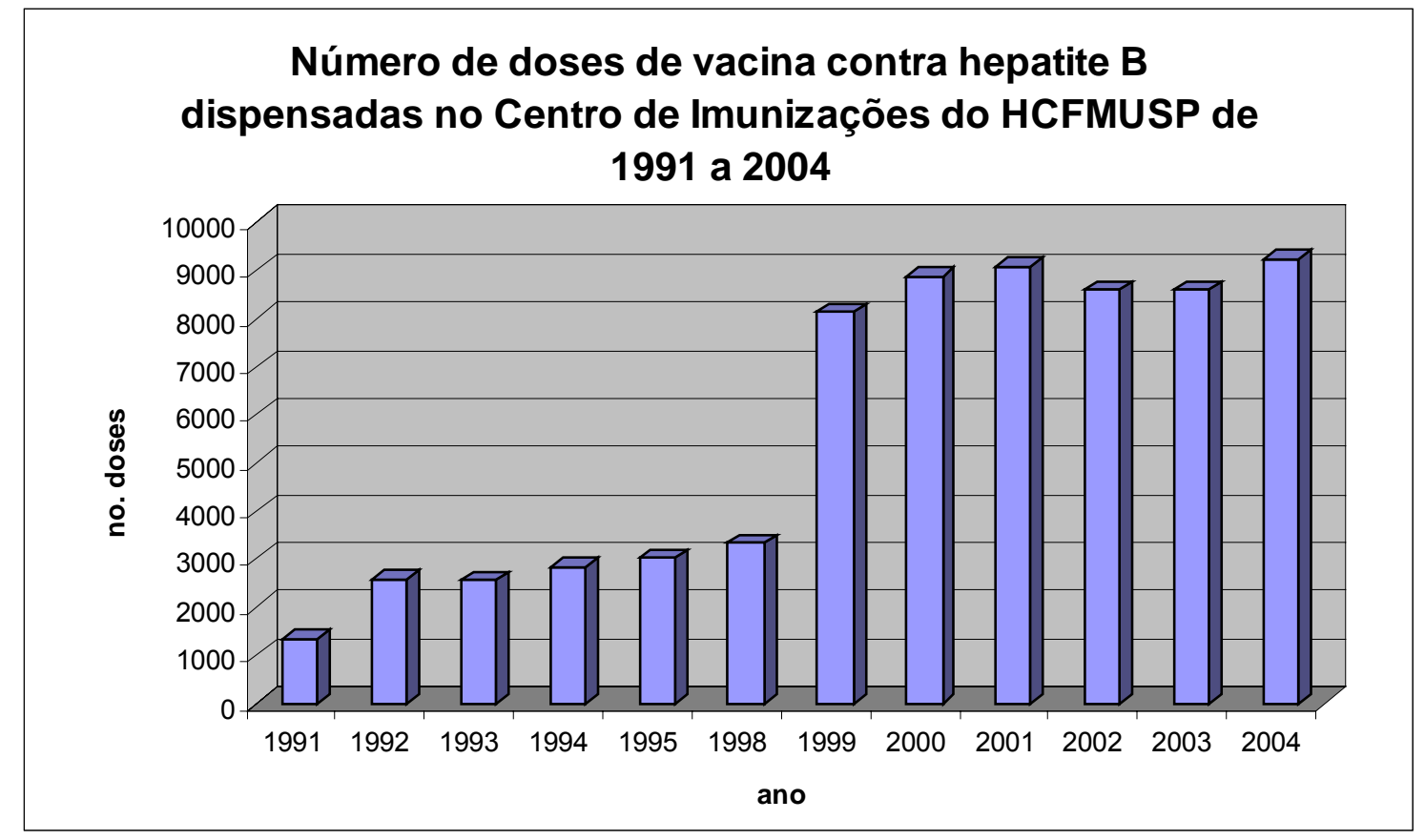


Gráfico 10

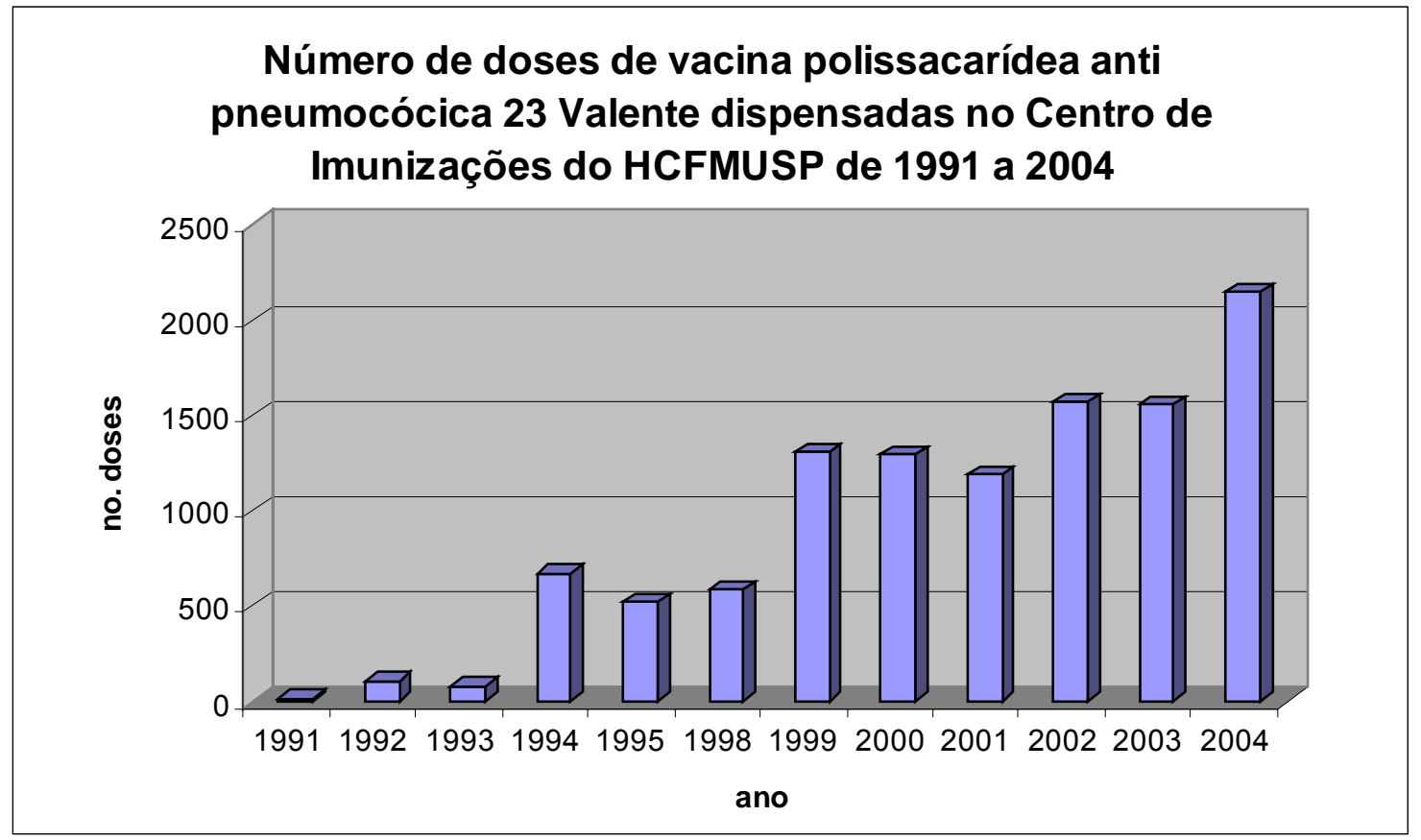

Gráfico 11

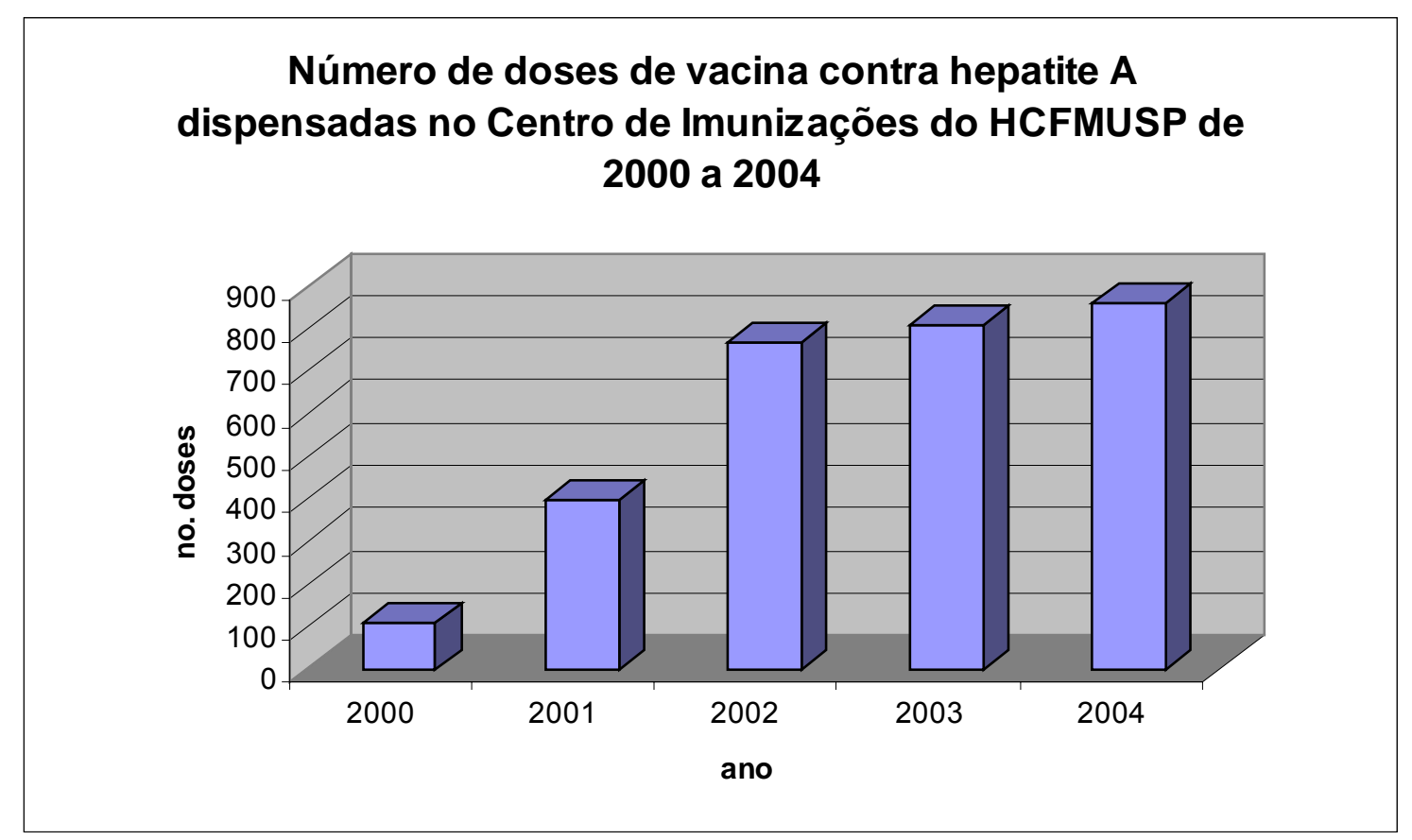


Gráfico 12

Número de doses de vacina anti pneumocócica conjugada 7 Valente dispensadas no Centro de Imunizações do HCFMUSP de 2002 a 2004

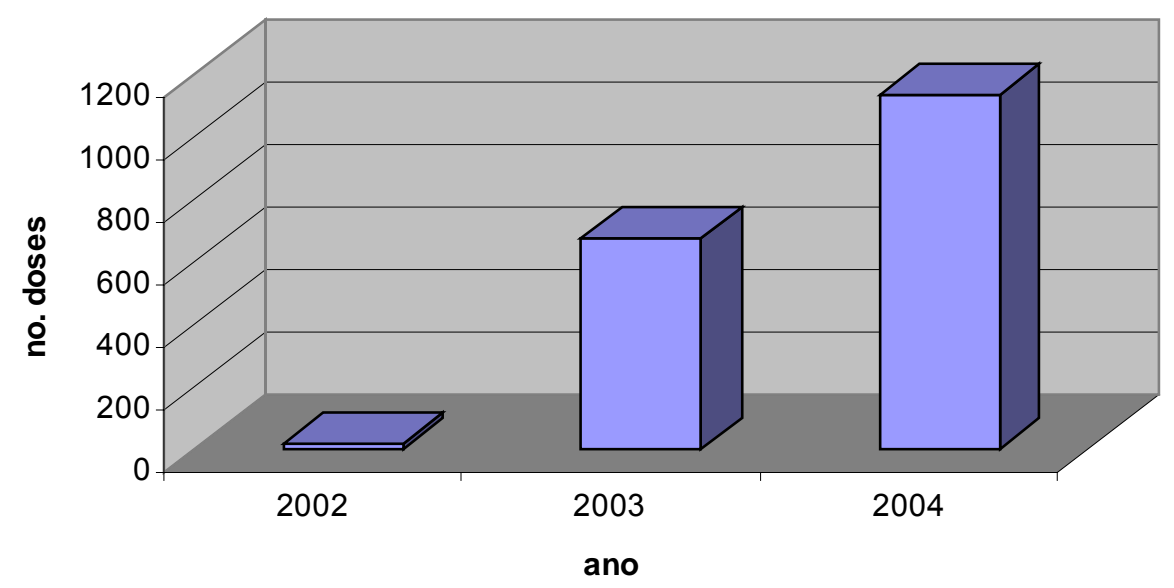

\section{Gráfico 13}

Número de doses de vacina conjugada contra meningococo $\mathrm{C}$ dispensadas no Centro de Imunizações do HCFMUSP de 2002 a 2004

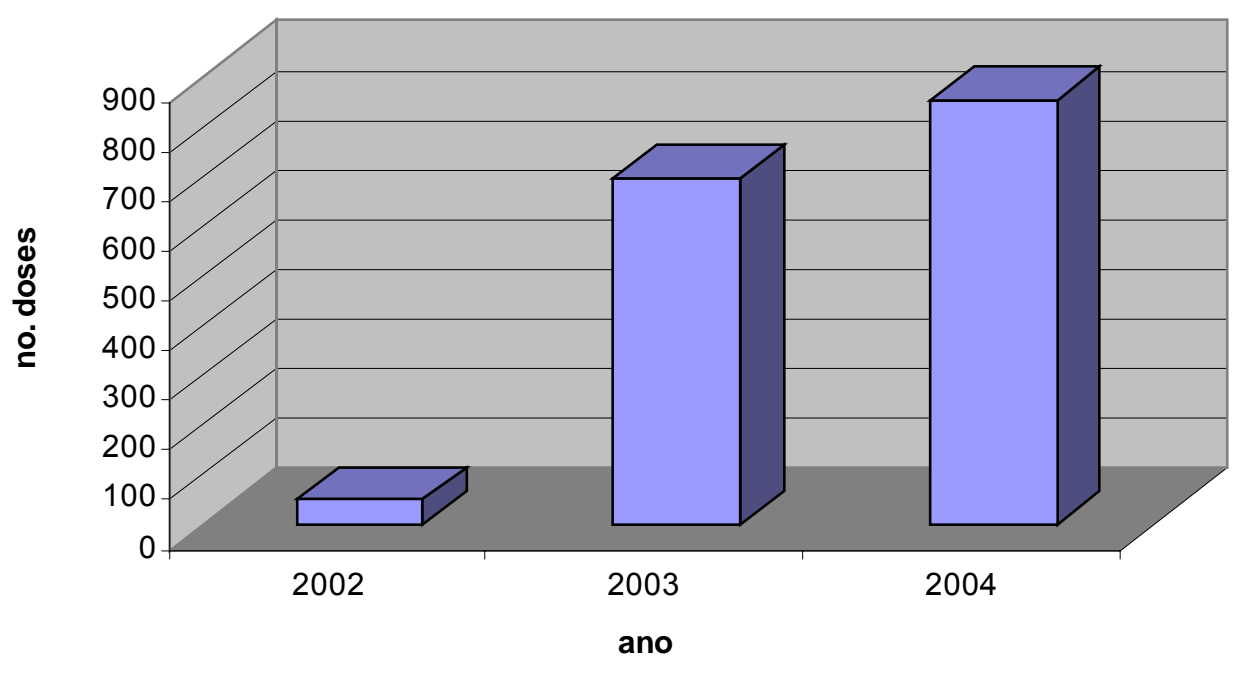


Buscamos sempre ampliar as indicações de vacinação e atingir o maior número possível de pessoas. A operacionalização desta estratégia nem sempre é simples. Desde a implantação do CRIE em dezembro de 1993 a dispensação de vacinas e imunoglobulinas passou a ser feita durante 24 horas. Para isso, foi necessário capacitar os plantonistas da Divisão de Clínica de Moléstias Infecciosas e Parasitárias. Cumprindo nossa missão de ensino, elaboramos Manual do Centro de Imunizações, de divulgação interna para os médicos da Divisão de Clínica de Moléstias Infecciosas e Parasitárias. O manual tinha como objetivo orientar a administração de imunobiológicos - vacinas e imunoglobulinas - no Complexo HC. O rigor no cumprimento das normas de dispensação de imunobiológicos, que sempre norteou nosso trabalho, nos levou a acrescentar na introdução do manual o seguinte esclarecimento: "Os imunobiológicos aplicados pelo Centro de Imunizações do HCFMUSP são provenientes de três fontes distintas: Ministério da Saúde, Secretaria de Estado da Saúde de São Paulo e do próprio Hospital das Clínicas da FMUSP, responsável pela compra de alguns desses produtos. Cada uma destas instituições, motivada pela crônica escassez de recursos, elaborou normas próprias de administração dos imunobiológicos, mais restritas do que as indicações encontradas na literatura. Portanto, para que um determinado imunobiológico seja liberado e/ou administrado pelo Centro de Imunizações, deve-se considerar a origem deste imunobiológico e observar se o caso em questão, além da correta indicação técnica, se enquadra nos parâmetros adotados pela fonte fornecedora". Dessa maneira buscávamos ir além do oferecido pelo Ministério da Saúde, ainda que isto significasse muita argumentação para que a compra fosse efetuada pelo Hospital e muito treino para que a dispensação ocorresse adequadamente.

Sempre buscando ampliar o número de pessoas vacinadas participamos de algumas campanhas e empreendemos outras.

\subsubsection{Campanhas de vacinação: Sarampo:}

No segundo semestre de 1996, foi detectado um aumento do número de casos de sarampo notificados à Secretaria de Estado da Saúde, concentrado na região metropolitana de São Paulo, nos municípios de Guarulhos e Poá. O aumento de casos manteve-se em 1997, sendo que, até 01/04/1997 haviam sido notificados 104 casos, a maioria confirmada sorologicamente. A situação configurava uma epidemia de sarampo. A distribuição dos casos, de 1996 e 1997, por faixa etária, mostrava que $65 \%$ dos pacientes tinham mais de 15 anos de idade.

No início de abril de 1997, foi realizada reunião no Hospital das Clínicas da FMUSP, congregando o Centro de Imunizações do HCFMUSP, o Núcleo de

\footnotetext{
* Centro de Imunizações do Hospital das Clínicas da Faculdade de Medicina da Universidade de São Paulo Gutierrez EB, Zeigler R, Lopes MH, Sartori AM, Tengan FM, Andreolli RMM. Manual do Centro de Imunizações. 1998. (Documento interno).
} 
Epidemiologia do Hospital das Clínicas da FMUSP, a Comissão de Bioética do HCFMUSP, e a Comissão Permanente de Assessoramento em Imunizações da Secretaria de Estado da Saúde de São Paulo. Este colegiado avaliou, considerando a situação epidemiológica do sarampo no Estado de São Paulo, ser necessário vacinar os alunos e funcionários do complexo HC/FMUSP, na faixa de 24 a 35 anos de idade. Isto porque estes indivíduos poderiam não ter sido vacinados na infância, uma vez que as coberturas vacinais não eram boas na época, e poderiam também não ter tido contacto com o vírus selvagem. Diferente da situação da população com mais de 35 anos, que viveu situação de ampla disseminação do vírus, com alta incidência da doença. Entretanto, aqueles que não relatassem antecedentes de sarampo e vacinação, mesmo fora da faixa etária estabelecida, também poderiam ser vacinados.

A campanha ocorreu de 14 a 18 de abril de 1997, e a vacina usada foi a tríplice viral, contra sarampo, caxumba e rubéola, acompanhada do seguinte alerta: "A vacina não é recomendada para gestantes. As mulheres vacinadas deverão evitar a gravidez pelo menos por 12 semanas".

Para viabilizar a estratégia nos cinco institutos e nos hospitais auxiliares que constituem o complexo HC, havia, além do espaço do Centro de Imunizações, um posto de vacinação em cada unidade, com funcionários capacitados, sob coordenação do Centro de Imunizações do $\mathrm{HC}^{32}$.

\section{Influenza:}

Desde 1997, o Centro de Imunizações do HCFMUSP vem fazendo anualmente campanha de vacinação contra influenza. A princípio restrita aos pacientes e funcionários do $\mathrm{HC}$, de 65 anos ou mais, e posteriormente aberta para toda população coberta pela campanha nacional (gráfico 14).

\section{Gráfico 14}




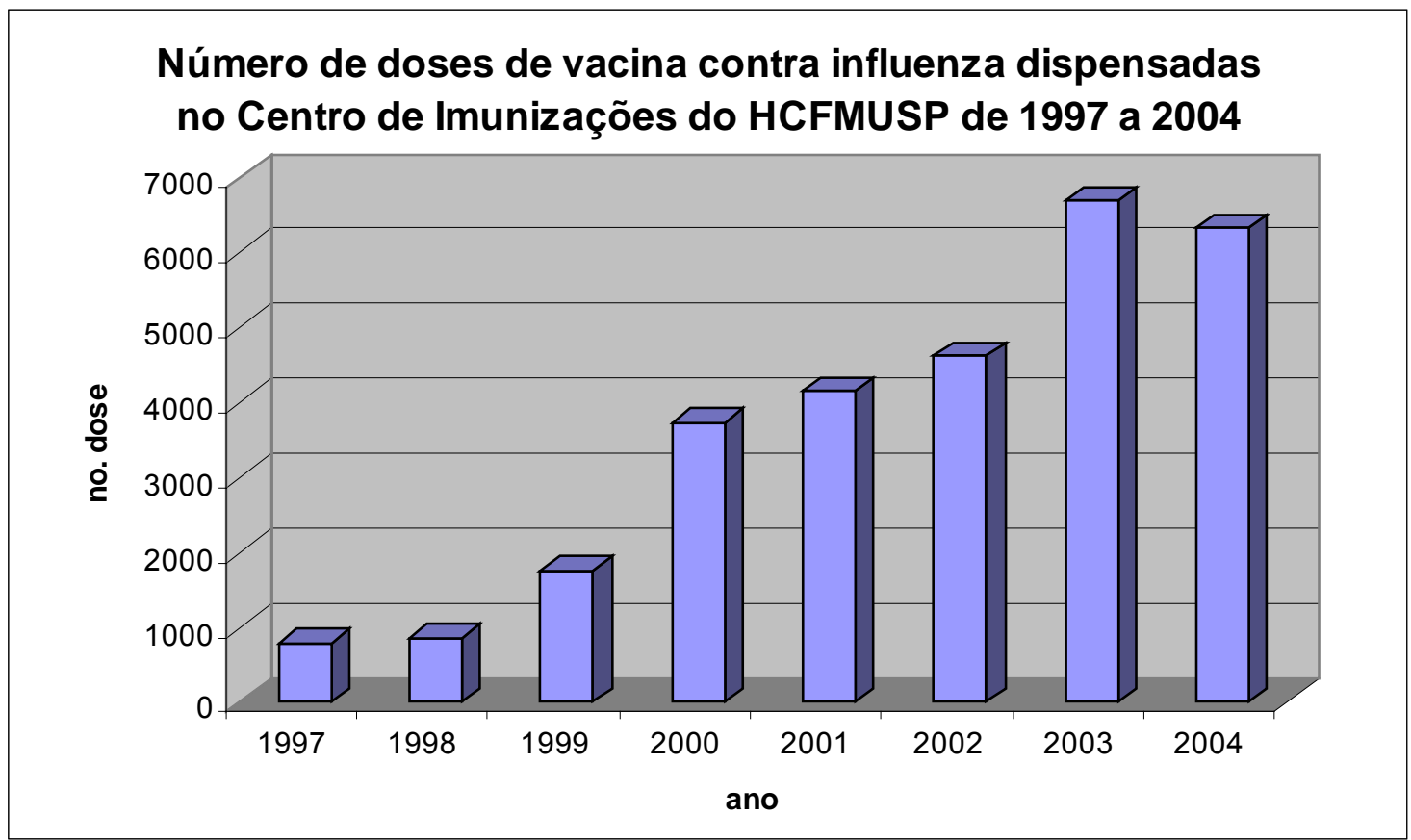

\section{Sarampo / Rubéola / Varicela}

De 05 a 16 de novembro de 2001 foi realizada, pela Secretaria de Estado da Saúde de São Paulo, campanha de vacinação contra rubéola e sarampo para mulheres de 15 a 29 anos de idade. O Centro de Imunizações do HCFMUSP participou e fez simultaneamente campanha de vacinação contra varicela para os funcionários do Complexo do Hospital das Clínicas (figura 1), tendo aplicado 450 doses de vacina contra varicela e 2988 doses de vacina dupla viral (sarampo e rubéola).

Figura 1

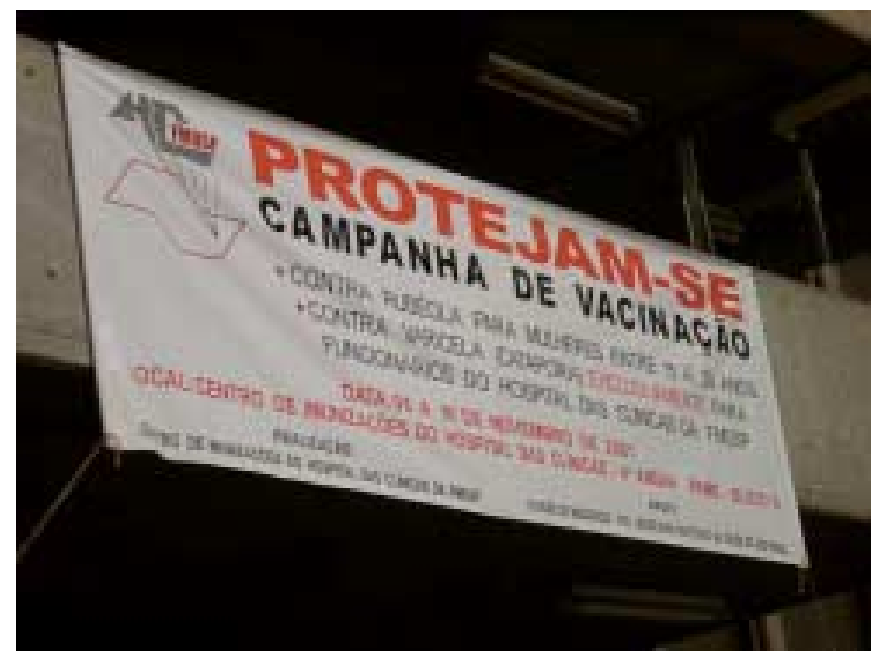




\section{Funcionários da Faculdade de Medicina da USP}

Desde 2000 vêm se promovendo campanhas de atualização de vacinação dos funcionários da Faculdade de Medicina da USP.

\section{Filhos de funcionários do Hospital das Clínicas da FMUSP}

A Divisão de Imunizações da Secretaria de Estado da Saúde de São Paulo tem empenhado esforços no sentido de ampliar a vacinação de adolescentes. Engajado nesta atuação, em outubro de 2004, o Centro de Imunizações do HC promoveu campanha de esclarecimento voltada para os filhos de todos os funcionários do complexo $\mathrm{HC}$, alertando-os para a importância e disponibilidade da vacina contra hepatite $B$, para crianças e adolescentes até 19 anos de idade ${ }^{33}$.

Concomitantemente a todas essas atividades descritas, a equipe do CRIE HC SP atende em consulta, diariamente, os usuários com queixas de eventos adversos relacionados à vacinação e às muitas solicitações de orientações, via telefone, que nos são dirigidas, uma vez que somos referência para a rede de saúde.

\subsubsection{Programas relacionados ao Centro de Imunizações}

Durante 0 trabalho do dia-a-dia, na dispensação rotineira dos imunobiológicos especiais, nas orientações sobre vacinação, foi surgindo a percepção de problemas mais amplos, mas que, de algum modo, estavam relacionados à vacinação.

\subsubsection{Programa de profilaxia após acidente com material biológico.}

Uma das atividades desenvolvidas no ano de 1998, que merece destaque, é a implantação do "Programa de profilaxia após acidente com material biológico".

Antes mesmo da implantação do CRIE, a profilaxia pós-acidente com material biológico era motivo de grande preocupação para a equipe do Centro de Imunizações do HC. Desde que assumimos o Centro de Imunizações, procuramos estimular a vacinação contra hepatite $B$ entre os funcionários do complexo HC/FMUSP.

Já na avaliação do primeiro ano de funcionamento do $\mathrm{CRIE}^{30}$, despertava a atenção, por motivo oposto ao descrito em relação ao encaminhamento de transplantados para vacinação, a procura relativamente pequena por esquemas profiláticos pós-exposição ao vírus da hepatite B (VHB). Embora as normas de distribuição contemplassem ampla gama de situações, tais como: filhos de mães portadoras do vírus da hepatite B (VHB), comunicantes sexuais e familiares de indivíduos infectados pelo $\mathrm{VHB}$, além de acidentados com material potencial ou comprovadamente infectado, a demanda era baixa. Neste primeiro ano, foram encaminhados para profilaxia pós-exposição 107 casos $(14,3 \%$ de todos os indivíduos atendidos). Cinqüenta e cinco casos receberam profilaxia ativa contra hepatite $B$, sendo que destes, 50 receberam concomitante a imunoglobulina 
humana hiperimune anti-hepatite $B(\mathrm{HBIG})$. Dos 55 casos que receberam a profilaxia pós-exposição contra hepatite $\mathrm{B}$, mais de $90 \%$ foi por acidente com material contaminado. Os demais encaminhamentos para profilaxia pós-exposição estavam relacionados à raiva e varicela. A média do tempo em horas decorrido entre o acidente ou contato e a chegada ao CRIE foi alta, 47 horas, sendo que, em $14,9 \%$ dos casos, ultrapassou 72 horas, o que mostrava a necessidade do fluxo ser agilizado.

Conforme já assinalamos, as normas do CRIE contemplam a dispensação de imunobiológicos na profilaxia pós-exposição de hepatite $B$, varicela e raiva. Com a implantação do CRIE, percebemos que a falta de informação sobre profilaxia pós-acidente com material biológico ocorria também fora do HCFMUSP, o que acarretava, com relativa freqüência, prescrições inadequadas, não só em relação à hepatite $B$ e $C$, mas também ao vírus da imunodeficiência humana (HIV). No Congresso da Sociedade Brasileira de Medicina Tropical, realizado no início de 1995, apresentamos os dados iniciais deste atendimento do $\mathrm{CRIE}^{34}$. Chamava a atenção o fato do perfil sorológico para o vírus da hepatite $\mathrm{B}$ do material infectante ser desconhecido em $77 \%$ dos casos. Ou seja, o material do caso fonte não estava sendo coletado, conforme recomendações da literatura ${ }^{35}$. Nesta mesma análise ${ }^{34}$, dos 70 profissionais de saúde acidentados $88,58 \%$ não eram previamente vacinados contra hepatite B.

Desde então, procuramos convencer os gestores do HCFMUSP da importância do atendimento de urgência a profissionais de saúde expostos a infecções preveníveis. Tal procedimento não se limita às medidas profiláticas pósexposição, mas deve servir também como subsídio para a adoção de medidas profiláticas pré-exposição.

Em 1998 foi implantado pela Diretoria Executiva do Instituto Central do Hospital das Clínicas, sob coordenação da Divisão de Clínica de Moléstias Infecciosas e Parasitárias, o programa "Profilaxia após acidente com material biológico", destinado aos funcionários, estudantes e estagiários do complexo Hospital das Clínicas / Faculdade de Medicina da USP. Fui nomeada, desde a sua criação, coordenadora deste Programa, posição esta que ocupo até os dias atuais.

As diretrizes e normas elaboradas pela Dra. Eliana Battaggia Gutierrez, médica do Centro de Imunizações, e por mim, derivaram da necessidade que percebíamos, na prática, de um atendimento profilático especializado e organizado pós-acidente com material biológico. Os acidentados são inicialmente atendidos pela enfermagem, que os encaminha para atendimento médico no Pronto Atendimento da Divisão de Clínica de Moléstias Infecciosas e Parasitárias. Este atendimento compreende anamnese, exame físico, pedido de sorologia do acidentado e do caso fonte (quando isto for possível) e prescrição de profilaxia, drogas nos casos de profilaxia anti-HIV e doença de Chagas e vacina e/ou imunoglobulina no caso de hepatite B. A seguir, a enfermagem orienta a coleta de sangue, a obtenção da profilaxia e os procedimentos para a Comunicação de Acidente de Trabalho (CAT). As condutas são tomadas baseadas no fato da fonte de infecção ser conhecida ou desconhecida. Assim, o médico pode optar por aguardar a sorologia do caso fonte. Os exames de dosagem de anticorpos antiHIV, do caso fonte são processados no setor de urgência do laboratório. Por fim, é agendado retorno para seguimento no ambulatório específico de acidentes com 
material biológico. Este ambulatório é realizado pelos médicos infectologistas da Divisão de Clínica de Moléstias Infecciosas e Parasitárias do HCFMUSP, que acompanham os acidentados por seis a 12 meses.

Estão envolvidos neste atendimento, além da Divisão de Clínica de Moléstias Infecciosas e Parasitárias (incluindo o Centro de Imunizações), a Divisão de Enfermagem, o Laboratório Central, a Divisão de Farmácia, a Divisão de Arquivo Médico (que dá suporte para o registro dos atendimentos) e o Núcleo de Informações em Saúde (NIS) do HCFMUSP, atualmente denominado Comitê Central de Epidemiologia, que é o responsável pela notificação dos acidentes ao Sistema de Vigilância da Secretaria de Estado da Saúde de São Paulo. Esta organização, simples, que contempla a união de várias áreas de trabalho sem subordinação de umas às outras, é um modelo de atuação facilmente reprodutível, que pode ser implantado em qualquer hospital. 
A implantação deste programa, de assistência multiprofissional, aos acometidos por acidentes com material biológico em um hospital de ensino foi relatada, enfocando o atendimento prestado pela enfermagem, no Congresso Nacional de Enfermeiros de novembro de 1999, em São Paulo. O programa como um todo foi apresentado no XXXV Congresso da Sociedade Brasileira de Medicina Tropical $^{36}$.

No ano de 2000 foram administradas 1264 doses de imunógenos no programa de profilaxia após acidente com material biológico, o que representava o dobro do ano anterior (639 doses em 1999), demonstrando a maior procura por este tipo de atendimento. Com o correr dos anos e a maior cobertura vacinal contra hepatite $B$, principalmente entre os funcionários do complexo HC FMUSP, observou-se, como pretendíamos, menor número de dispensação de imunógenos para profilaxia pós-exposição (gráfico 15).

\section{Gráfico 15}

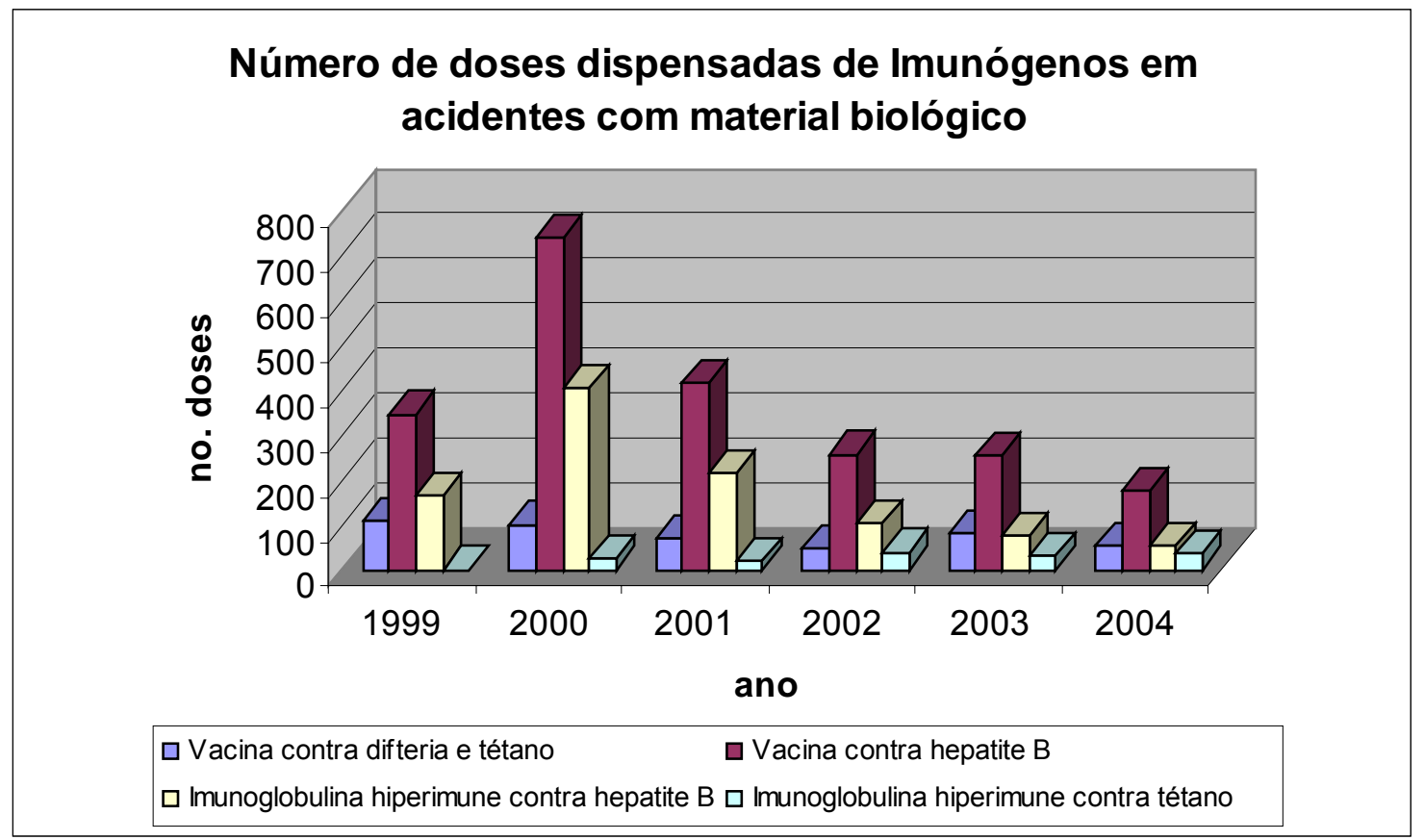

Neste programa, o atendimento imediato ao acidentado é realizado por equipe composta de médicos e enfermeiros e compreende anamnese e prescrição de conduta profilática, que engloba: a) pedido de sorologia para hepatite $B$, hepatite C, HIV e doença de Chagas, do acidentado e do caso fonte (quando isto é possível); b) prescrição de drogas nos casos de profilaxia anti-HIV e doença de Chagas; c) prescrição de vacina e/ou imunoglobulina no caso de profilaxia antihepatite $B$; d) acompanhamento sorológico por até 12 meses após o acidente; e) nos casos de acidente com material contaminado com vírus da hepatite $C$, não há conduta profilática pós-exposição de eficácia estabelecida, portanto só é feito o acompanhamento sorológico. As condutas são tomadas com base no fato da fonte 
de infecção ser conhecida ou desconhecida e seguem determinações estabelecidas pelos órgãos competentes do Ministério da Saúde do Brasil ${ }^{37}$, baseadas em recomendações internacionais ${ }^{35}$.

Em 2004, encaminhamos para publicação, tendo como autora principal a médica Eliana Battaggia Gutierrez, o relato de toda esta experiência ${ }^{38}$. Constatamos que a fonte do material biológico causador do acidente era conhecida em $80,7 \%$ dos 404 casos analisados e que $83 \%$ dos acidentados foram atendidos em até três horas após o acidente. Estes dados refletem o bom funcionamento do programa e são importantes, uma vez que as medidas profiláticas pós-exposição devem ser rápidas e eficientes ${ }^{35}$.A análise dos casos fonte mostrou que $24,5 \%$ tinham evidências sorológicas de infecção por um ou mais agentes: $16,2 \%$ eram anti-VHC positivos, $10,9 \%$ HIV positivos e $3,8 \%$ AgHBs positivos.

Os mecanismos responsáveis pelos benefícios da profilaxia pós-exposição para HIV não são claros. As recomendações atuais são baseadas na patogênese da infecção e na plausibilidade biológica de que essa infecção possa ser prevenida pelo uso de drogas anti-retrovirais ${ }^{39,40,41}$. Cardo $^{42}$, em um estudo caso controle, analisando 33 indivíduos expostos que soroconverteram, e 679 pessoas expostas que não soroconverteram (controles), observaram $81 \%$ de redução no risco de infecção pelo HIV entre os profissionais que receberam zidovudina como profilaxia pós-exposição.

Dos 404 profissionais de saúde acidentados, analisados em nosso trabalho, $67 \%$ completaram o seguimento de 12 meses proposto, sem ocorrência de soroconversão. A baixa prevalência de profissionais de saúde acidentados infectados pelo VHB (0,9\% eram AgHBs no momento do acidente) e encontro de aproximadamente $70 \%$ com anti-HBs positivo, são evidências indiretas de razoável cobertura vacinal, embora a ideal seja de $90 \%$.

Dos acidentados, $0,5 \%$ estava infectado pelo HIV no momento do acidente. Mas 3,1\% eram portadores do VHC, fato este que, aliado ao encontro de que a infecção mais freqüente entre os casos fonte foi a pelo $\mathrm{VHC}$, nos deixaram particularmente preocupados. Neste caso, o acompanhamento se reveste de especial importância. Não há medidas profiláticas pós-exposição eficazes, entretanto há relatos na literatura ${ }^{43}$ de clareamento do $\mathrm{VHC}$ após o uso de interferon em 33 de 34 indivíduos agudamente infectados pelo VHC. Embora esta recomendação não esteja plenamente estabelecida na literatura, não pode deixar de ser discutida com o acidentado, caso ocorra soroconversão.

Esta investigação, além de mostrar excesso de prescrição de drogas antiretrovirais, vacina e imunoglobulina contra hepatite $B$, nos levou a recomendar 0 encurtamento do tempo de acompanhamento pós-acidente, de 12 para seis meses, seguindo recomendações da literatura ${ }^{35}$. Espera-se que esta redução no tempo de seguimento diminua os abandonos e aumente a aderência.

\subsubsection{Vacinação para o Ambulatório dos Viajantes}

Iniciado em dezembro de 2000, o Ambulatório dos Viajantes compartilha o mesmo espaço físico do Centro de Imunizações. Este ambulatório, coordenado pelo professor Marcos Boulos, e dirigido a princípio pela Dra. Eliana Battaggia 
Gutierrez e a seguir pela Dra. Melissa Mascheretti, é fruto de convênio entre a Divisão de Clínica de Moléstias Infecciosas e Parasitárias do HCFMUSP e a Superintendência de Controle de Endemias (SUCEN) de São Paulo.

Consta de seus objetivos, entre outros, a profilaxia pré-viagem em relação às doenças imunopreveníveis. Desde então temos vacinado, sempre de acordo com as normas de dispensação de imunobiológicos estabelecidas pelo $\mathrm{PNI}$, os viajantes que procuram este ambulatório. A partir de 2002, por nossa solicitação, 0 PNI passou a enviar para o CRIE vacina contra febre tifóide, que é utilizada para viajantes, em casos específicos (gráfico 16).

\section{Gráfico 16}

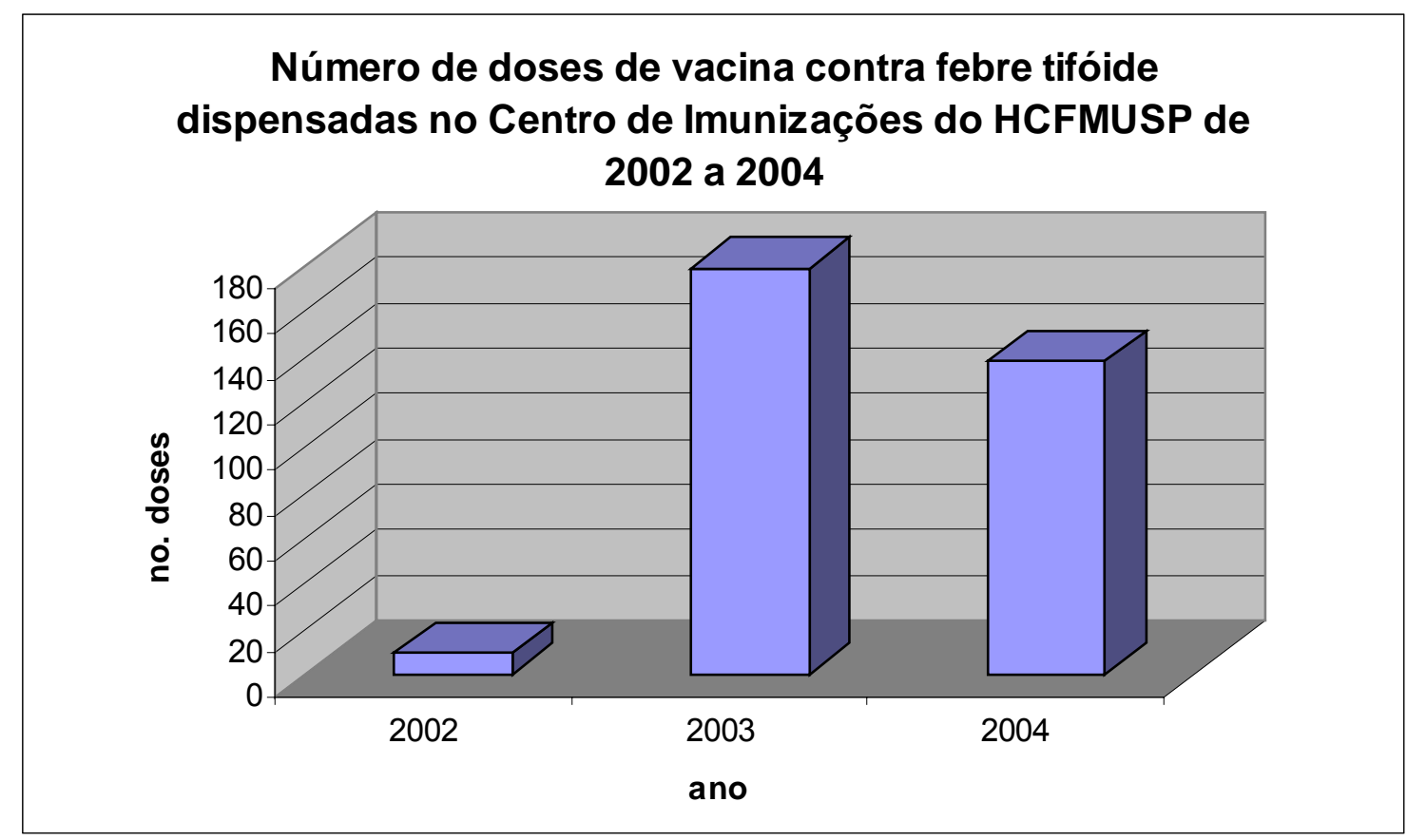

\section{Vacina contra Febre Amarela}

Em decorrência das atividades do Ambulatório dos Viajantes, para as quais - Centro de Imunizações contribui com a aplicação das vacinas indicadas, aumentou a demanda pela vacina contra febre amarela (gráfico 17). Por este motivo, desde 2002, houve ampliação do horário de atendimento para realização desta vacina, que passou a ser administrada diariamente. A partir do segundo semestre de 2002, por nossa solicitação, o Centro de Imunizações do HCFMUSP, sob a supervisão da Agência Nacional de Vigilância Sanitária (ANVISA), passou a fornecer o Certificado Internacional de Vacinação contra a febre amarela. 


\section{Gráfico 17}

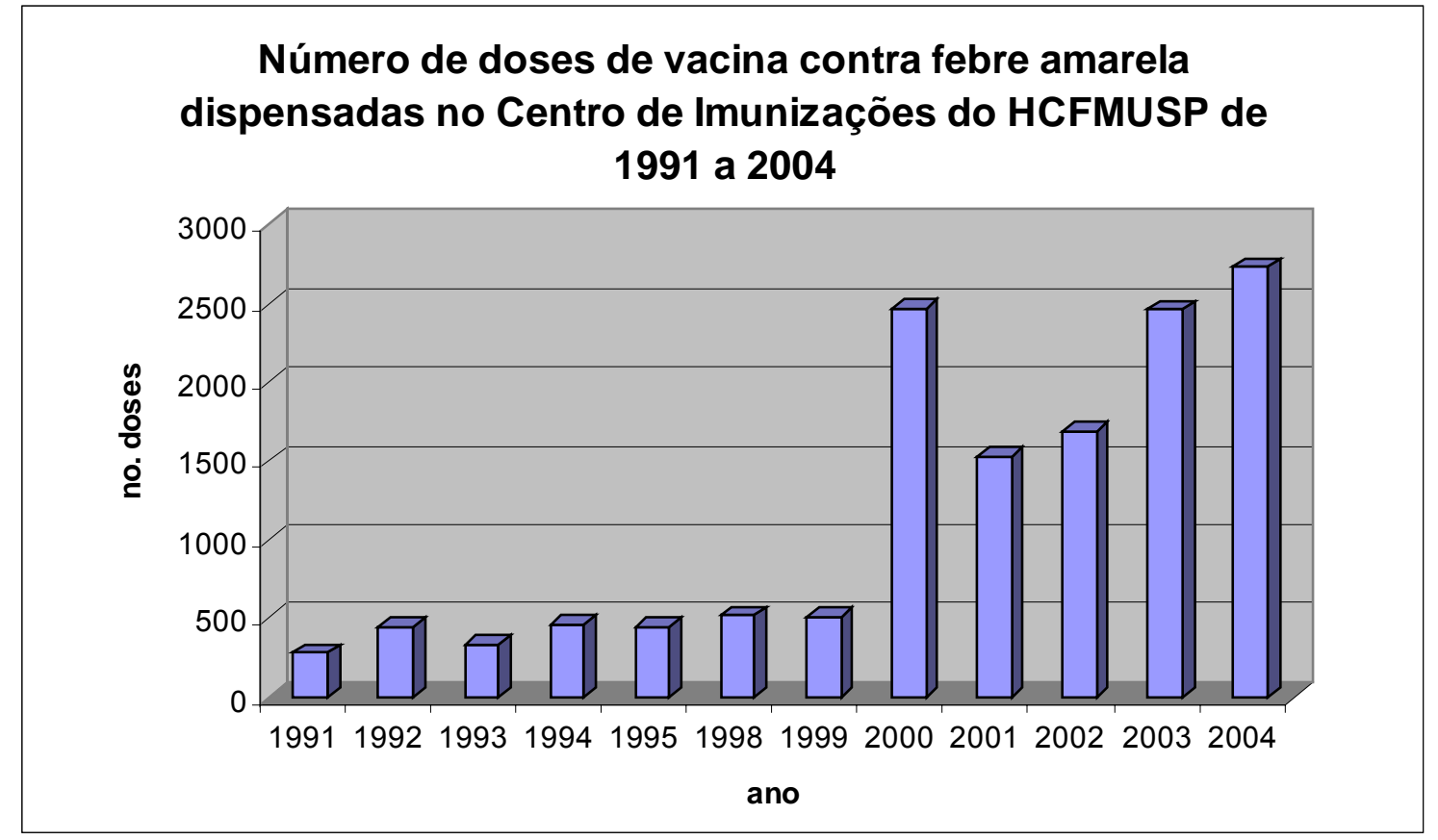

\section{ATIVIDADES DE ENSINO NO CRIE HC SP}

Desta intensa atividade assistencial sempre participaram os alunos e estagiários que passaram pelo Centro de Imunizações. Além disso, procuramos estimular a investigação científica e envolvê-los em projetos em andamento, ou incentivá-los a comunicarem em congressos suas observações decorrentes da prática em imunizações.

As atividades formais de ensino que implantei e desenvolvi nestes 11 anos de CRIE compreendem:

\section{Supervisão de Estagiários}

1- Estágio optativo, de quatro semanas, aos médicos residentes do Departamento de Moléstias Infecciosas e Parasitárias da FMUSP. A partir de 2005, este estágio passa a fazer parte das atividades obrigatórias para os residentes de terceiro ano do Departamento de Moléstias Infecciosas e Parasitárias da FMUSP

2- Estágio optativo, de quatro semanas, para médicos residentes do Departamento de Pediatria da FMUSP e para médicos do Curso de Especialização em Pediatria do Departamento de Pediatria da FMUSP. 
3- Estágio de médico observador: realizado pelo médico Paulo J. Bianchin, no ano de 1994, que foi estimulado a realizar trabalho de investigação científica, relatado em congresso ${ }^{44}$..

4- Estágio de um ano de duração no Curso de Especialização em Imunizações do Departamento de Moléstias Infecciosas e Parasitárias da FMUSP: realizado pelo médico Wagner Abreu, durante o ano de 2004.

\section{Cursos Ministrados}

1- Módulo de Imunizações no XXIX Curso de Especialização em Medicina Tropical em 1993. Duração: 16 horas.

2- Módulo de Imunizações no XXX Curso de Especialização em Medicina Tropical em 1994. Duração: 16 horas.

3- "Imunizações" no XXXI Congresso Brasileiro de Medicina Tropical, realizado em São Paulo, SP, de 28 a 31 de março de 1995.

4- Módulo de Imunizações no XXXI Curso de Especialização em Medicina Tropical em 1995. Duração: 16 horas.

5- Módulo de Imunizações no XXXII Curso de Especialização em Medicina Tropical em 1997. Duração: 16 horas.

6- Módulo de Imunizações no XXXIII Curso de Especialização em Medicina Tropical em 1999. Duração: 16 horas.

7- "Imunizações", coordenado por Ana Marli Christovan Sartori e Marta Heloisa Lopes, oferecido aos médicos do Programa de Residência Médica do Departamento de Moléstias Infecciosas e Parasitárias da FMUSP, de 22/10/03 a $27 / 11 / 03$.

\section{Disciplinas ministradas na Graduação da FMUSP}

Disciplina optativa: "Imunizações", MIP 203, oferecida nos anos de 1999, 2000, 2002 e 2004.

Disciplina optativa: "Iniciação Científica à Prática Médica".

Um aluno no primeiro semestre de 2000. O trabalho elaborado e desenvolvido pelo aluno, sob minha orientação e da Dra. Eliana B. Gutierrez, foi publicado no Boletim da Sociedade Brasileira de Imunizações ${ }^{45}$.

Disciplina optativa: "Introdução à pesquisa científica em medicina" MSP-273. Um aluno no segundo semestre de 1997.

Dois alunos no segundo semestre de 1998.

Disciplina de Pós-Graduação: Em 2004, nos sentindo, Ana Marli C. Sartori e Marta Heloisa Lopes, agora aptas a oferecermos uma disciplina de pósgraduação, enviamos à Comissão de Pós Graduação (CPG) da FMUSP solicitação de criação de nova disciplina, intitulada "Imunizações". A disciplina foi aprovada pela CPG em outubro de 2004 e será ministrada em 2005.

Orientações para alunos de graduação e de pós-graduação senso lato e senso estrito. 
1- Programa bolsa trabalho: Projeto Número 0108/97- Vacinação com Imunobiológicos Especiais em Pacientes Imunocomprometidos.

Aluno de graduação da FMUSP: Nélio Reis Ferreira no ano de 1997.

Aluno de graduação da FMUSP: José Leonardo de Souza Júnior no ano de 1998.

2- Projetos de iniciação científica: Alunas de graduação da FMUSP Maura S. Oliveira e Mariana Maleronka Ferron, em 2000 e em 2001, cujas investigações sobre "Vacinação em gestantes infectadas pelo vírus da imunodeficiência humana" ${ }^{46}$ e "Perfil do conhecimento de alunos e residentes do HCFMUSP sobre profilaxia do tétano" ${ }^{47}$, respectivamente, foram relatadas em congresso.

3- Orientações de médicos residentes do terceiro ano do Departamento de Moléstias Infecciosas e Parasitárias da FMUSP na realização de monografias:

1992: Noêmia Barbosa Carvalho - "Infecções em asplênicos".

1992: Lia Márcia Massini Canedo Rocha - "Profilaxia da hepatite B".

1994: Juliane Gomes de Paula - "Imunizações em indivíduos infectados pelo vírus da imunodeficiência humana". Esta orientação culminou com a publicação de livreto sobre o tema ${ }^{48}$.

1994: Sonia Maria Geraldes - "Política de vacinação e revacinação com BCG. Considerações epidemiológicas".

1995: Marcio Vieira Santos - "Vacina inativada contra Hepatite A". O produto desta monografia foi publicado na Revista da Sociedade Brasileira de Medicina Tropical $^{49}$.

2000: Max Igor Banks Ferreira Lopes - "Vírus Influenza: aspectos gerais e prevenção".

2001: Tálib Moysés Moussalem - "Profilaxia após acidente com material biológico".

2002: Alexandre Rodrigues da Silva - "Inquérito sobre situação vacinal de médicos residentes de um hospital de ensino".

2002: Lourênia Mendonça Cassoli - "Resposta imunológica ao HIV após acidentes ocupacionais".

4- As orientações de pós-graduação senso estrito resultaram em publicações que são discutidas adiante.

\section{O CRIE HC SP e a INVESTIGAÇÃO CIENTÍFICA}

Muitas das atividades de ensino e assistência estão relacionadas a publicações em congressos e algumas a publicações em revistas científicas e de divulgação:

Lopes MH, Amato Neto V. Imunizações em pacientes infectados pelo HIV. Imunizações. $1997^{50}$

Lopes MH, Amato Neto V. Vacinação de adultos. Imunizações.1997 ${ }^{51}$. 
Lopes MH. O Programa Nacional de Imunizações no Brasil e a cogitação de ampliação. Imunizações. $1998^{52}$.

Lopes MH, Amato Neto V. Vacinas recomendáveis para diabéticos. Imunizações. $1999^{53}$.

Moussalem TM, Schout D, Lopes MH. Sarampo no HC-FMUSP: perfil clínico epidemiológico - 1989 a 2000. Rev Soc Bras Med Trop. $2002^{54}$.

Também produzimos material didático incluindo manuais e capítulos de livros: Lopes $\mathrm{MH}$. Vacinação na criança e no adulto. In: Manual de condutas médicas. Instituto para o Desenvolvimento da Saúde. São Paulo: Universidade de São Paulo, Ministério da Saúde; $2002^{55}$.

Lopes MH. Raiva. In: Amato Neto V, Baldy JLS, Silva LJ. Imunizações. $3^{a}$ ed. São Paulo: Sarvier; $1991^{56}$.

Lopes MH. Meningites bacterianas agudas. Profilaxia e vacinas. In: Machado LR, Livramento JÁ, Spina-França Netto A, Nóbrega JPS, editores. Neuroinfecção 96. São Paulo: Clínica Neurológica HC/FMUSP; $1996^{57}$.

Lopes MH. Vacinação preventiva da hepatite B: obrigatoriedade em profissionais da área da saúde. In: Weckx LY, Amato Neto V. Controvérsias em imunizações. São Paulo: Lemos Editorial; $2002^{58}$.

Lopes MH. Vacina preventiva da hepatite B em infectados pelo HIV: dose dupla também nos assintomáticos; uso independentemente da contagem de linfócitos CD 4 no sangue. In: Weckx LY, Amato Neto V. Controvérsias em imunizações. São Paulo: Lemos Editorial; $2002^{59}$.

Entendemos que compartilhar nossos conhecimentos é uma forma de atuar no processo ensino / aprendizagem, e por maior que seja a rotina, procuramos pensar criticamente nosso trabalho e divulgar os conhecimentos obtidos através dele.

As publicações foram sempre um trabalho de parceria entre a equipe do Centro de Imunizações e os médicos dos Serviços responsáveis pelo encaminhamento dos pacientes.

- Assim é que, relacionado ao atendimento de crianças com doenças da coagulação, encaminhadas pelo Dr. Jorge D. A. Carneiro, relatamos em congresso a nossa experiência em vaciná-las contra hepatite $B$, por via subcutânea, evitando assim os sangramentos decorrentes da injeção intramuscular ${ }^{60}$.

- Atendimento aos pacientes transplantados de medula óssea resultou em pelo menos uma publicação ${ }^{61}$.

- A rotina de vacinação dos alunos de graduação da Faculdade de Medicina da Universidade de São Paulo também foi relatada em congresso.

Em 1998, o programa de vacinação dos alunos de graduação da FMUSP foi reformulado. Em parceria com os responsáveis pela disciplina "Introdução à prática clínica" e com o Laboratório Central do $\mathrm{HC}$, estabeleceu-se a seguinte dinâmica: durante o estágio na referida disciplina, os alunos do primeiro ano 
treinam punção venosa periférica, colhendo sangue uns dos outros, sendo as amostras encaminhadas para realização de sorologia para hepatite B. Após o resultado dos exames sorológicos os alunos eram encaminhados para vacinação. Aos alunos que, por qualquer motivo, não obedecessem a este fluxograma, eram administradas as três doses da vacina, mesmo sem sorologia prévia.

Esta reformulação foi analisada e comunicada no XXXV Congresso da Sociedade Brasileira de Medicina Tropical, no início de $1999^{62}$. Obtiveram-se 113 amostras de soro de um total de 180 alunos regularmente matriculados no primeiro ano. Estas amostras foram submetidas à pesquisa de AgHBs, anti-HBs e anti-HBc total, pelo método imunoenzimático. Os resultados obtidos revelaram que $87,6 \%$ destes alunos eram negativos para todos os marcadores investigados e, portanto, suscetíveis à infecção pelo VHB. 9\% eram anti-HBs positivos, isoladamente, indicando vacinação prévia, e os restantes $3,4 \%$ eram anti-HBc positivos. Nenhum dos alunos analisados era portador do VHB. Levando-se em consideração estes achados, concluiu-se que a sorologia pré-vacinação tinha um rendimento muito baixo como exame de triagem neste grupo específico, além de poder interferir diminuindo a aderência dos alunos à vacinação. A partir destes dados, passamos a recomendar a realização de sorologia só pós-vacinação, visando documentar a resposta à vacina.

Este mesmo programa de vacinação dos alunos foi avaliado em 2000, por um aluno do curso de graduação da FMUSP, Eduardo Massato Hasegawa, enquanto cursava, no Centro de Imunizações, a Disciplina "Iniciação à Prática Médica" (disciplina optativa da FMUSP). O estudo procurou determinar o perfil da situação vacinal dos alunos regularmente matriculados no primeiro e segundo anos de graduação, do ano letivo de 2000, na Faculdade de Medicina da USP. Do primeiro dia útil de fevereiro até o último dia do mês de maio, 123 de 366 alunos $(33,6 \%)$ compareceram para serem vacinados. Houve maior adesão por parte dos primeiro-anistas, que corresponderam a 67,5\% (82 / 123) dos vacinados, e de alunos do gênero feminino. A maior adesão dos calouros era de se esperar, uma vez que parte dos segundo-anistas já havia sido vacinada no ano anterior. Dos alunos que aderiram ao programa, $71,8 \%$ referiram não ter sido vacinados contra hepatite $\mathrm{B}$ anteriormente. Os baixos índices de adesão ao programa de vacinação encontrados nesta avaliação, somados ao alto índice de alunos não previamente vacinados contra hepatite $B$, indicavam que os estudantes de medicina ingressantes na FMUSP naquele ano não estavam adequadamente protegidos contra doenças imunopreveníveis. Discutimos no artigo publicado com os resultados desta avaliação ${ }^{45}$ que a baixa taxa de adesão a um programa de vacinação gratuito contrastava com altas taxas de adesão encontradas entre alunos canadenses ${ }^{63}$ e norte-americanos ${ }^{64}$, locais onde as vacinas de rotina nem sempre são gratuitas como no Brasil. Embora a maioria das escolas médicas desses países forneça algum tipo de subsídio aos seus alunos para as vacinas requeridas no ato da matrícula, ou antes de iniciar o internato, são raras as escolas médicas que as fornecem gratuitamente. Concluímos pela necessidade de mais ampla divulgação e mais discussões para conscientização de alunos e professores tanto sobre a prática de imunização quanto de medidas profiláticas em geral. 
Nossas principais investigações, entretanto, desde que assumimos a responsabilidade pelo Centro de Imunizações do HC, em 1991, têm se pautado por assuntos específicos, entre os quais a vacinação de adultos e a vacinação de pacientes imunodeprimidos.

\subsection{VACINAÇÃO DE ADULTOS}

A vacinação de adultos é um assunto sobre o qual temos nos manifestado algumas vezes ${ }^{51,65}$. Segundo o Manual de Procedimentos para Vacinação, do Ministério da Saúde, publicado em $2000^{16}$ "O planejamento deve ocorrer dentro de um processo dinâmico capaz de permitir revisões periódicas de objetivos, prioridades e estratégias, seja em função dos avanços registrados, seja em decorrência dos obstáculos que eventualmente vão sendo defrontados. $\mathrm{Na}$ imunização, por exemplo, a revisão de prioridades e estratégias é muito comum: na década de 80 a prioridade era quase que exclusiva para o grupo dos menores de cinco anos, hoje, com o surgimento de outras vacinas ou de outros grupos suscetíveis, amplia-se a oferta de produtos e a faixa etária de atendimento, exigindo um reposicionamento em termos de metas e estratégias". Já em análise datada de outubro de $1993^{*}$, sobre o programa de vacinação contra hepatite B iniciado no HC em 1983, salientamos a importância, muitas vezes esquecida, dos programas de vacinação para adulto. A análise desse programa de vacinação para funcionários e médicos residentes do HCFMUSP e alunos de graduação da FMUSP, durante os anos de 1990, 1991 e 1992, mostra que 1960 indivíduos iniciaram o esquema de vacinação contra hepatite B nestes três anos. Destes, $1735(89,75 \%)$ completaram o esquema de três doses*. Nesta época era priorizada a vacinação da população de risco para aquisição da infecção pelo vírus da hepatite $B$, tanto entre funcionários, quanto entre os pacientes, excluindose, por exemplo, funcionários administrativos. O fato de quase $90 \%$, destes indivíduos, terem completado o esquema vacinal punha em dúvida afirmação, corrente na época, segundo a qual adultos eram resistentes a programas de vacinação. Estes números, ainda que modestos, refletiam os esforços da equipe do Centro de Imunizações do HCFMUSP na conscientização dos vacinados sobre a importância da finalização do esquema, e na busca ativa dos indivíduos que atrasavam para o retorno programado.

Só a partir de 2004 o Ministério da Saúde (MS) do Brasil passa a adotar três calendários de vacinação, incluindo o de adultos, em todo o território nacional. A portaria número 597 , do MS, de 08 de abril de 2004, publicada no Diário Oficial da União $n^{\circ}$ 69, seção 1, e modificada em 07 de outubro de 2004, estabelece as vacinas, doses e períodos de vacinação do calendário básico de vacinação da criança, do calendário de vacinação do adolescente e do calendário de vacinação do adulto e do idoso ${ }^{66}$.

\subsubsection{VACINAÇÃO DE IDOSOS}

\footnotetext{
* Centro de Imunizações do HCFMUSP - Avaliação das Atividades Desenvolvidas no Centro de Imunizações do HCFMUSP de 1991 a 1995 (Documento interno).
} 
A vacinação de idosos tem sido objeto de estudo por parte da equipe do Centro de Imunizações.

Os alunos de iniciação científica Nélio Ferreira e Antônio Lerário ${ }^{67}$ nos ajudaram na organização e no posterior relato do pioneiro Programa de Vacinação do Idoso, desenvolvido pelo Centro de Imunizações e pela Clínica de Geriatria do HCFMUSP, em 1997, quando a vacinação de idosos não era rotina no país, nem no estado, nem no município. O Programa atingiu 794 pacientes. A avaliação de sua implantação foi feita por meio da análise das informações obtidas de uma amostra constituída por 257 indivíduos vacinados. A maioria destes pacientes (96\%), de risco para as complicações da influenza, não havia sido imunizada anteriormente e só teve acesso a este imunógeno através deste Programa. Observou-se também que a vacinação contra influenza teve um papel impulsionador em relação às outras vacinas recomendadas para esta faixa etária. Embora as vacinas contra tétano e difteria já estivessem disponíveis em toda a rede pública há muitos anos, $81 \%$ dos 257 analisados não estavam com sua vacinação em dia, e foram vacinados durante a campanha de vacinação contra influenza realizada em 1997, no HC FMUSP.

Nesta mesma época participamos, com a Clínica de Geriatria e o Instituto Adolfo Lutz, de investigação sobre a resposta de anticorpos pós-vacinação contra pneumococo em idosos. Foi avaliada a resposta imune de 103 idosos (61 a 88 anos de idade) antes e após a administração de vacina 23-valente. Foi verificada a produção de lgG contra os sorotipos 1, 5 e 6B (polissacarídeos capsulares purificados), que são os mais freqüentemente associados a doença invasiva em idosos no Brasil. A maioria dos idosos apresentava anticorpos anti-polissacarídeos antes da vacinação. A concentração média de $\operatorname{lgG}(\mathrm{em} \mu \mathrm{g} / \mathrm{mL})$ nos soros pré e pós vacinação para os antígenos polissacarídeos 1, 5 e 6B foi: 3,5 / 7,1; 2,5 / 7,6 e 4,4 / 8,2 respectivamente. Estes valores correspondem a um aumento médio de duas vezes para os sorotipos 1 e $6 \mathrm{~B}$, e de três vezes para o sorotipo 5 . A vacinação resultou portanto em um aumento da concentração de $\lg G$ contra os três sorotipos na maioria dos indivíduos ${ }^{68}$.

Estes dados, ainda que preliminares, davam subsídio para nossas atividades de vacinação dos idosos contra o pneumococo.

A partir de 1998, a princípio no município de São Paulo e, nos anos seguintes, em todo o território nacional, instalou-se a campanha de vacinação de idosos contra influenza, tétano e difteria, e, para os de maior risco, também contra pneumococo. Em 1999, julgando que poderia ser útil para os que estavam iniciando esta atividade, relatamos no Congresso Brasileiro de Medicina Tropical nossa experiência com a vacinação de idosos ${ }^{69}$. A vacina contra influenza, de acordo com dados de literatura obtidos predominantemente em populações de países do hemisfério norte, se mostrava efetiva para idosos e pacientes com doenças crônicas de base. A Dra. Eliana Battaggia Gutierrez propôs então que, no Centro de Imunizações do HCFMUSP, fizéssemos uma investigação para avaliar o nível de proteção conferido pela vacina contra influenza nos idosos aí vacinados.

O estudo, retrospectivo, foi feito durante a campanha anual de vacinação contra gripe de 2000 . Os idosos, ao chegarem para se vacinar, eram submetidos a um questionário aplicado pelas residentes do terceiro ano de Moléstias Infecciosas, que estavam estagiando no Centro de Imunizações, Ho Yeh Li e Ana 
Catarina de Seixas Santos O questionário continha informações demográficas, sobre situação de saúde, hábitos e sobre ter recebido ou não vacinação contra gripe na campanha do ano de 1999. Foram analisados 187 indivíduos, distribuídos em dois grupos: a) 131 vacinados contra influenza no ano de 1999; b) 56 não vacinados. Os dois grupos foram semelhantes com respeito às condições de saúde, características demográficas, tabagismo e alcoolismo. No ano que se seguiu à vacinação os vacinados relataram número de episódios clinicamente definidos como gripe, isto é, sem confirmação laboratorial, significativamente menor do que os não vacinados ${ }^{70}$.

Concluímos que a vacina contra influenza contribuiu para redução do número de episódios caracterizados como gripe, nesta parcela de idosos. Sabemos das limitações e vieses deste estudo, mas achamos que seria importante como ponto de partida para outros estudos. Pretendemos agora ampliar esta avaliação para segmentos mais amplos da população brasileira.

Em 2002, investigamos os eventos adversos pós-vacinação contra influenza, na população-alvo da campanha, constituída por idosos e por profissionais de saúde do Hospital das Clínicas da FMUSP, que atendem diretamente idosos e imunodeprimidos. Considerando-se que, em 2001, o CRIE HC SP vacinou 4145 pessoas contra influenza e que a freqüência esperada de eventos adversos, em adultos, é de cerca de $10 \%^{71}$, o tamanho da amostra calculada foi de 200 pessoas. As pessoas selecionadas foram contatadas por telefone, sete dias após a vacinação. As ligações foram feitas pelos estudantes de graduação de iniciação científica, pela médica estagiária e pelos médicos assistentes do Centro de Imunizações. Os eventos adversos relatados foram semelhantes aos descritos na literatura. Eventos de caráter subjetivo, como dor no local da injeção, cefaléia, mialgia, mal-estar e coriza foram mais freqüentes nos funcionários do que nos idosos $(p<0,05)$. Não houve diferença estatisticamente significativa na ocorrência de febre. Este trabalho foi submetido à publicação, e estamos aguardando a resposta. A sua divulgação nos parece importante uma vez que não se confirmou a crença, de parcela da população, que credita à vacina contra influenza eventos adversos freqüentes e desconfortáveis. Além disso, as reações subjetivas foram mais freqüentes nos profissionais de saúde, o que pode influenciar de forma negativa a divulgação dos benefícios desta vacina, dado o seu papel de formadores de opinião.

\subsection{Vacinação de Imunodeprimidos}

Como responsável pelo Centro de Referência para Imunobiológicos Especiais do HCFMUSP desde sua implantação, em dezembro de 1993, e decorrente do interesse despertado pelo tema de um dos objetivos primordiais dos CRIEs, que é a imunização de adultos e crianças imunocomprometidas, procuramos investigar alguns dos muitos aspectos não esclarecidos envolvidos na imunização de pacientes imunodeprimidos.

Várias são as condições que levam ao comprometimento, quer da imunidade humoral, quer da imunidade celular, ou de ambas: imunodeficiências congênitas; condições que causam deficiência imune específica, como asplenia, 
insuficiência renal crônica, hepatopatias, diabetes, uso de corticosteróides; infecção pelo vírus da imunodeficiência humana; imunodepressão grave decorrente de transplantes, neoplasias.

No século XX ocorreu um grande aumento no número de pessoas com comprometimento da imunidade, decorrente do uso de drogas imunossupressoras, do aumento da sobrevida de pacientes com doenças neoplásicas, do aprimoramento das técnicas de transplante de órgãos e em decorrência da infecção pelo HIV.

As infecções nos pacientes imunocomprometidos podem ter evolução mais grave, como é o caso, por exemplo, da varicela, doença geralmente benigna na criança imunocompetente, mas cuja mortalidade é superior a $10 \%$ nas crianças com leucemia. Além disso, em termos de saúde coletiva os hospedeiros imunocomprometidos representam um desafio no controle das doenças infecciosas, uma vez que podem se constituir em grupos de indivíduos suscetíveis, mantendo a circulação dos agentes etiológicos. A importância de vacinar os pacientes imunodeprimidos reside não só na proteção do paciente contra infecções graves, mas, do ponto de vista de saúde pública, na necessidade de impedir que aumente o número de indivíduos suscetíveis, que podem ser responsáveis pela manutenção da circulação do agente etiológico.

Por outro lado, os diferentes comprometimentos do sistema imunológico têm influência tanto na efetividade da imunização, quanto no risco de eventos adversos decorrentes da vacinação. Há várias evidências na literatura, que serão discutidas a seguir, de resposta diminuída à vacinação, em indivíduos imunodeprimidos. $O$ uso de alguns imunobiológicos pode acarretar, particularmente em pessoas com comprometimento da imunidade celular, graves eventos adversos.

Toda terapia, incluindo a administração de vacinas, envolve uma decisão risco-benefício. Para a maioria das vacinas, os benefícios superam grandemente os riscos. Mas estes parâmetros geralmente são definidos no contexto do hospedeiro normal. Quase todas as vacinas licenciadas, em uso atualmente, foram desenvolvidas para administração em indivíduos com imunidade normal, e a avaliação da imunidade conferida por estas vacinas também foi realizada, quase que exclusivamente, em hospedeiros saudáveis.

A resposta imune é extraordinariamente complexa, e muitos aspectos permanecem pouco entendidos. A vacinação nem sempre leva à imunização, particularmente nos imunocomprometidos. Entretanto, são justamente estes pacientes que apresentam maior potencial de risco de desenvolver doença grave. A equação risco-benefício para o uso da maioria das vacinas vivas atenuadas em pacientes imunocomprometidos é complexa, porque esta população tem um risco alto de infecção grave pelo patógeno selvagem. Por este motivo, vacinas contra sarampo, por exemplo, são usadas em crianças infectadas pelo HIV, uma vez que os reais riscos da doença superam os potenciais riscos da vacinação.

Decorrente do exposto deve-se levar em conta os seguintes dados quando da vacinação de imunocomprometidos: 1) prevalência e gravidade da infecção; 2) natureza do defeito imune do indivíduo; 3 ) eficácia e segurança da vacina. 
Desde o início das atividades do CRIE, nós nos preocupamos com a segurança das vacinas nos pacientes imunodeprimidos. Em relato publicado em 1995, na Revista da Sociedade Brasileira de Medicina Tropical ${ }^{44}$ apresentamos os dados referentes à investigação de eventos adversos relacionados às vacinas contra Haemophilus influenzae tipo b e contra pneumococo, em 54 crianças com diferentes condições patológicas. Concluímos que, nestas crianças, os eventos adversos não foram nem mais freqüentes, nem mais graves que em crianças imunocompetentes.

A avaliação da verdadeira eficácia das vacinas em pacientes com imunidade comprometida permanece um desafio. Estes indivíduos representam uma população heterogênea e a prevalência da maioria das infecções preveníveis por vacinação é muito baixa para rapidamente se avaliar a eficácia em populações relativamente pequenas.

Como se observa, a vacinação de pacientes imunodeprimidos requer atenção especial. Entretanto nas últimas décadas vem crescendo o número de pacientes nestas condições. No Centro de Imunizações do Hospital das Clínicas da FMUSP, que é um Centro de Referência em Imunobiológicos Especiais (CRIE), a vacinação de pacientes imunodeprimidos é atividade diária. Esta situação estimula a atualização científica da equipe e impõe desafios.

\subsubsection{Vacinação de transplantados}

Conforme já relatado, desde o início das atividades do CRIE chamou atenção o encaminhamento sistemático e organizado de transplantados e candidatos à transplante de órgãos, predominantemente do Serviço de Transplante de Medula Óssea (TMO) do HCFMUSP.

No início dos anos 2000, a exemplo do que já vinha acontecendo com a vacinação dos transplantados de medula óssea, organiza-se, em conjunto com o doutor Edson Abdalla, infectologista do grupo de transplante hepático, o encaminhamento para vacinação de candidatos, doadores e transplantados de fígado, estabelecendo-se, assim, protocolo de vacinação para estes pacientes.

Como reflexo da prática sistemática de vacinação de candidatos a transplante, doadores e transplantados, em 05/06/2003 fui nomeada, pelo Diretor Clínico do Hospital das Clínicas da FMUSP, por meio da portaria número 016/3, representante do Centro de Imunizações do HCFMUSP, junto ao Grupo de Infecção em Transplante, vinculado à Comissão de Transplante de Órgãos e Tecidos e Comissão de Controle de Infecção Hospitalar do Hospital das Clínicas da FMUSP.

Mas nosso desafio era chegar junto aos grupos de transplante menos receptivos à prática de imunização. Com a colaboração decisiva da Dra. Lílian Monteiro Pereira e o apoio incondicional do professor doutor Elias David-Neto, a médica Tânia do Socorro Souza Chaves iniciou em 2001 sua dissertação de mestrado, que consistia em: 1) verificar os registros de vacinação das crianças transplantadas renais acompanhadas no ambulatório da Unidade de Transplante 
Renal da Divisão de Clínica Urológica do Hospital das Clínicas da FMUSP; 2) avaliar a prevalência de anticorpos contra o vírus varicela-zoster (VVZ) nestas crianças transplantadas renais; 3 ) identificar e vacinar contra varicela as crianças com baixos títulos de anticorpos anti-VVZ.

A adesão dos pais e pacientes foi significativa: das 56 crianças e adolescentes acompanhados na Unidade de Transplante Renal do HCFMUSP, 50 participaram do protocolo. Destas, 46 tinham carteira de vacinação, das quais $52 \%$ estavam com as vacinas de rotina atualizadas. Considerando-se as vacinas de rotina e as vacinas especiais preconizadas para transplantados renais, só duas crianças estavam com a carteira de vacinação atualizada, ou seja, 95\% estavam com esquema vacinal atrasado. Estes dados servem de alerta para os responsáveis por programas de transplantes, que envolvem procedimentos de alto custo e alta complexidade, mas por vezes negligenciam procedimentos gratuitamente disponíveis, que podem melhorar as condições de vida destes pacientes e mesmo contribuir para aumento da sobrevida ${ }^{72}$.

Consideramos este estudo, cuja publicação está no prelo $^{73}$, muito importante por vários aspectos A soroprevalência de anticorpos anti-VVZ encontrada nesta população foi de $88 \%$, sendo que 12 crianças $(24,5 \%)$ apresentavam títulos de anticorpos menores que 0 índice arbitrariamente considerado protetor. Seis destes 12 pacientes foram vacinados contra varicela e quatro $(66,6 \%)$ responderam à vacinação, sem apresentar reações adversas. Este é o segundo trabalho publicado de vacinação contra varicela em transplantados renais. Durante este estudo mantivemos contato, por correio eletrônico, com a Dra. Isabel Zamora, autora do primeiro e até então único trabalho na literatura de vacinação contra varicela em transplantados renais ${ }^{74}$.

As conclusões desta investigação mostraram que cerca de $25 \%$ das crianças transplantadas renais acompanhadas no ambulatório da Unidade de Transplante Renal eram potencialmente suscetíveis à infecção pelo vírus varicelazoster. Uma destas crianças desenvolveu varicela durante o período de investigação. A vacinação destes pacientes é uma medida profilática que deve ser considerada, e estudos multicêntricos, envolvendo maior número de transplantados devem ser realizados.

Esta pesquisa nos chamou também a atenção para dúvidas, que remetem a outras investigações. Estudos de epidemiologia molecular demonstram que o herpes zoster pode ocorrer tanto por reativação de cepa vacinal latente, quanto por reativação de cepa selvagem latente, embora as reativações sejam mais freqüentes após infecção pelo vírus selvagem.

Embora a varicela seja a manifestação clínica caracteristicamente observada em decorrência da infecção primária, há vários relatos na literatura de pacientes imunodeprimidos com mais de um episódio de varicela.

Feldhoff e colaboradores ${ }^{75}$, acompanhando 160 crianças transplantadas renais, observaram que 19 tiveram varicela em uma semana a seis anos após o transplante. Em três destas crianças era o segundo episódio de varicela. Uma delas evoluiu para óbito, embora tenha recebido plasma hiperimune contra a varicela.

Feher e colaboradores ${ }^{76}$, revisando 34 casos de varicela em adultos transplantados renais, entre 1981 e 2000 , constataram 34\% de mortalidade. Em 
$82 \%$ dos casos era o primeiro episódio da doença, mas em $18 \%$ era o segundo episódio de varicela.

Rothwell e colaboradores ${ }^{77}$ relataram três casos de varicela grave, com manifestações de visceralização, em 19 crianças transplantadas renais. Das três crianças, duas já tinham tido varicela e uma havia sido vacinada antes do transplante. Estas três crianças tinham títulos positivos de anticorpos anti-varicelazoster (anti-VVZ) antes do transplante. Os autores levantam a hipótese de que o micofenolato mofetil, droga imunossupressora usada no pós-transplante, poderia levar a acentuada imunodepressão, causando a reativação do vírus varicela zoster, sob a forma de varicela.

No estudo que constituiu a dissertação de mestrado da Tânia Chaves das 12 crianças com títulos de anticorpos anti-VVZ menores que $500 \mathrm{mUA} / \mathrm{mL}$, cinco referiam já ter tido varicela, e uma já havia sido vacinada anteriormente. Uma das crianças, a com história confirmada de vacinação prévia contra varicela, desenvolveu a doença durante a investigação. Ela evoluiu com a forma clínica moderada, sendo internada e medicada com aciclovir, com boa resolução clínica.

Laube e colaboradores ${ }^{78}$, descrevendo a ocorrência de varicela em crianças com história prévia da doença, sugerem que títulos de anticorpos considerados protetores para crianças saudáveis podem não prevenir infecções em imunodeprimidos. A reativação do vírus VVZ em crianças submetidas a transplante de medula óssea está nitidamente relacionada ao declínio da imunidade celular.

Várias questões sobre a persistência da imunidade para varicela, e o melhor modo de avaliá-la nos pacientes imunodeprimidos, permanecem não resolvidas.

Pelo exposto se depreende a importância da profilaxia para varicela nos pacientes imunodeprimidos, particularmente naqueles com depressão da imunidade celular. A vacina, por ser de vírus vivos, é contra-indicada nestes pacientes, por muitos autores na literatura. A profilaxia pós-exposição assume então caráter particularmente importante. Pode ser feita com o uso de aciclovir, na dose de 40 a $80 \mathrm{mg} / \mathrm{k}$ de peso/dia, administrado por via oral a cada 6 horas, durante sete dias, iniciando o uso entre o sétimo e o nono dia após a exposição. Alguns autores, como Kanda e colaboradores ${ }^{79}$, preconizam o uso de aciclovir em baixa dose, por longo tempo, após transplante alogênico de medula óssea. Outra maneira de se fazer a profilaxia pós-exposição é com a imunoglobulina específica antivaricela-zoster (VZIG).

A VZIG é derivada de plasma humano com altos títulos de anticorpos específicos para o VVZ. A dose profilática é de $125 \mathrm{U}$ para cada $10 \mathrm{k}$ de peso corpóreo (mínimo de 125U e máximo de 625U).

As recomendações atuais em relação ao uso da VZIG, se restringem a pessoas suscetíveis ${ }^{t}$ imunodeprimidas ou com risco especial de varicela grave, que tenham tido contato significativo com doente de varicela em fase contagiosa.

A questão que se impõe é que é muito difícil avaliar o grau de proteção em relação à varicela no paciente com comprometimento da imunidade celular.

\footnotetext{
* São consideradas suscetíveis à varicela as pessoas sem história bem definida da doença e não vacinadas contra varicela.
} 
Relatos prévios de doença ou de vacinação não asseguram que este paciente não venha a desenvolver novamente varicela. Por outro lado, estes pacientes constituem grupo de especial interesse, uma vez que têm maior risco de desenvolver quadros graves, com complicações que podem ser fatais. Sendo assim, em capítulo escrito para o livro "Mais Controvérsias em Imunizações" (ainda no prelo), propomos a revisão das normas de profilaxia pós-exposição: em vez da indicação de VZIG só para os pacientes imunodeprimidos suscetíveis, que se indique VZIG para todos os pacientes com grave comprometimento da imunidade celular, independente de história prévia de varicela.

Ao final da dissertação de mestrado, propusemos também a inclusão de testes sorológicos para dosagem de anticorpos anti-VVZ na avaliação rotineira dos indivíduos transplantados renais, embora saibamos que o principal fator implicado nas reativações deste vírus seja a depressão da imunidade celular.

Como se vê, ainda há muitas questões a serem respondidas em relação a este assunto.

\subsubsection{Vacinação em pacientes infectados pelo HIV Questões relacionadas ao uso de vacinas em pacientes com HIV/Aids}

\subsubsection{Eficácia da vacinação}

No início da década de 90, do século XX, as principais questões sobre a vacinação de pacientes HIV/Aids estavam relacionadas à eficácia da vacinação.

Em 1994, durante seu estágio optativo no Centro de Imunizações como residente do terceiro ano de Moléstias Infecciosas, e instigada pelas constantes discussões sobre o tema, Juliane de Paula Amato, sob minha orientação, fez ampla revisão da literatura sobre o assunto. Resultou na monografia de conclusão do programa de residência: "Imunizações em indivíduos infectados pelo vírus da imunodeficiência humana (HIV)", posteriormente, com bibliografia ampliada, publicada sob a forma de livreto em $1997^{48}$.

Estes trabalhos compilados mostravam que: "Com base nos dados de revisão da literatura coletados, nota-se que existem dificuldades no estudo da resposta imunológica às vacinas, pois a maioria dos trabalhos apenas avaliam a presença ou não de soroconversão, inclusive utilizando como parâmetro níveis de anticorpos considerados protetores em populações sadias, sem estabelecer se estes níveis são igualmente protetores em indivíduos infectados pelo HIV. (...) Outro aspecto de relevância é o da falta de um seguimento mais prolongado dos pacientes inseridos nos diversos estudos, o que conseqüentemente limita as conclusões a respeito da proteção vacinal, assim como sobre quais seriam os melhores esquemas de imunização, a quantidade ideal de imunógeno por dose e a freqüência necessária de reforços para estes indivíduos. (...) Entretanto, ressalta-se que o receio quanto ao risco aumentado de eventos adversos não tem sido corroborado".

E a conclusão final apresentada no livro diz: "Atualmente, até que melhores estudos sejam realizados, a maior parte das vacinas estão indicadas para os 
indivíduos infectados pelo HIV, apesar da possibilidade de menores índices de soroconversão e menor persistência no título de anticorpos" ${ }^{48}$.

\subsubsection{O imunógeno aumenta a replicação do HIV?}

Estavámos empenhados na vacinação dos pacientes com HIV/Aids, quando, na metade dos anos 90 , foram publicados alguns trabalhos sugerindo que a administração de imunógenos aumentava, nos pacientes infectados, a replicação do vírus da imunodeficência humana.

O'Brien e colaboradores ${ }^{80}$, em 1995, relataram aumento da carga viral em 20 pacientes infectados pelo HIV, vacinados contra influenza. Em 14 pacientes também infectados e não vacinados não foi observada variação da carga viral.

Stanley e colaboradores ${ }^{81}$ relataram aumento da viremia após vacinação antitetânica. O aumento da viremia, após vacinação contra pneumococo, com a vacina polissacarídea 23-valente, também foi relatado por Brichacek e colaboradores $^{82}$.

Em seqüência começaram a ser publicados trabalhos com resultados diferentes dos anteriormente citados. Em investigação apresentada na " $36^{\text {th }}$ Interscience Conference on Antimicrobial Agents and Chemotherapy", realizada em Nova Orleans, no Estados Unidos, em 1996, Kroon e colaboradores ${ }^{83}$ não detectaram variação significativa da carga viral, nove dias após 15 pacientes infectados pelo HIV terem sido vacinados, em momentos diferentes, com vacina anti-pneumocócica conjugada, vacina anti-pneumocócica polissacarídea e vacina polissacarídea contra Salmonella typhi. Fowke e colaboradores ${ }^{84}$ vacinaram contra influenza 31 adultos infectados pelo HIV e não observaram aumento da carga viral do HIV, nem alteração da contagem dos linfócitos CD4. Em 39 crianças soropositivas para HIV vacinadas contra influenza e em nove vacinadas contra difteria, tétano e coqueluche (DTP), Donovan e colaboradores ${ }^{85}$ também não observaram variação significativa da carga viral pós vacinação.

Estava estabelecida a controvérsia em relação ao aumento da carga viral do HIV devido à vacinação. Nota-se, entretanto, que os trabalhos citados eram baseados em casuística pequena, e muitos deles foram desenvolvidos com metodologia inadequada para este tipo de investigação.

Esta controvérsia nos estimulou a desenvolver um projeto de estudo com a médica Sigrid de Sousa dos Santos, que a princípio seria sua dissertação de mestrado. O propósito desta investigação, desenvolvida no CRIE HC SP a partir de dezembro de 1998, era avaliar se a imunização com vacina conjugada contra Haemophilus influenzae tipo b (Hib) alterava a viremia e a contagem de células CD4 em pacientes infectados pelo HIV. Para isso, elaboramos projeto de um estudo com tamanho da amostra e metodologia adequadas, que nos permitisse conclusões pertinentes. O profundo envolvimento da pós-graduanda em todas as etapas do estudo, sua auto-suficiência na resolução dos problemas que apareciam no curso da investigação, e também a consistência dos dados obtidos, nos fizeram pleitear a passagem para doutorado direto, que foi autorizada.

Foram envolvidos no estudo 79 pacientes infectados pelo HIV: 60 foram randomizados para receber a vacina (grupo A) e 19 para não receber (grupo B). 
Vinte indivíduos soronegativos receberam a vacina (grupo C). Não havia diferenças demográficas significantes entre os grupos. A maioria dos pacientes infectados pelo HIV $(89,9 \%)$ estava tomando drogas anti-retrovirais, dos quais $64,8 \%$ recebiam terapêutica de alta potência. A contagem inicial de linfócitos $T$ CD4 + e a carga viral do HIV 1 não diferiam em ambos os grupos, o de vacinados e o de não vacinados infectados pelo HIV $(p>0,50)$. Foram colhidas quatro amostras de sangue para análises, de todos os pacientes infectados pelo HIV, a partir do momento em que os pacientes do grupo A recebiam a vacina: em 48 a 72 horas (primeira amostra), entre 2 a 4 semanas (segunda amostra), 4 a 6 semanas (terceira amostra) e 24 a 26 semanas (quarta amostra). Após a vacinação, não houve diferença em termos de variação percentual de CD4 entre os pacientes infectados pelo HIV vacinados e não vacinados. A variação percentual de CD4 foi menor que $25 \%$ em todas as observações, tanto do grupo A quanto do grupo B. A variação absoluta da carga viral do HIV1 mostrou progressão semelhante entre os pacientes infectados vacinados - grupo A e os pacientes infectados não vacinados - grupo B $(p=0,48)$. Entretanto notou-se entre os pacientes infectados pelo HIV reduzida resposta de anticorpos à vacina Hib. A imunogenicidade da vacina (avaliada por um aumento de títulos de anticorpos anti-PRP maior que quatro vezes após a vacinação) foi de $38,3 \%$ no grupo infectado e de $70 \%$ no grupo não infectado ${ }^{86}$.

Em 2000, Sullivan e colaboradores ${ }^{87}$ publicaram avaliação longitudinal retrospectiva de 45.617 pacientes com HIV/Aids acompanhados no Projeto de Vigilância do Espectro da Doença pelo HIV de adultos e adolescentes dos EUA. O período de análise foi de 1990 a 1998. Nesta observação não houve efeito da vacinação contra influenza na evolução da: 1) percentagem de linfócitos T CD4; 2) quantificação do RNA plasmático do HIV1; 3) progressão para Aids ou óbito.

Estes dados, somados a outros da literatura, indicavam, mais uma vez, que os benefícios da vacinação suplantavam os efeitos indesejáveis. Mas quem bem discutiu esse assunto, a meu ver, foi Glesby. Este autor já havia publicado, em $1996^{88}$, os resultados de pesquisa bem elaborada em que mostrava não haver aumento da viremia após vacinação contra influenza. Em 1998 relata, na revista Current Opinion in Infectious Diseases ${ }^{89}$, que os estudos que mostram incremento da carga viral do HIV após vacinação foram, em sua maioria, realizados na época em que somente eram disponíveis os medicamentos análogos de nucleosídeos para tratar a infecção pelo HIV. Os estudos conduzidos em pacientes já fazendo uso de terapêutica anti-retroviral de alta potência não evidenciam nem diminuição da contagem dos linfócitos T CD 4+, nem aumento da quantificação do RNA plasmático do HIV1.

\subsubsection{Como melhorar a resposta à vacinação?}

Conforme encontramos em nosso estudo com a vacina conjugada Hib, os indivíduos infectados pelo HIV apresentam menor resposta de anticorpos pósvacinação em relação aos não infectados. No artigo em questão ${ }^{86}$ discutimos que a progressão da infecção pelo HIV, além de levar a perda gradual da imunidade celular e humoral, leva a disfunções na diferenciação e proliferação dos linfócitos 
$B$, tanto de memória quanto para novos antígenos, que pode ser detectada em fases assintomáticas precoces da infecção, mesmo na ausência de relevante depleção de células CD4, como relatado por Steinhoff e colaboradores ${ }^{90}$.

Acompanhando a literatura, constatávamos que estudos do uso da vacina contra hepatite B em pacientes infectados pelo HIV também mostravam baixas taxas de soroconversão ${ }^{91}, 92,93,94,95$. Este era um dado particularmente preocupante, uma vez que a transmissão dessas duas infecções tem vários pontos em comum, e a vacinação contra hepatite $B$ é recomendada para pessoas infectadas pelo HIV e suscetíveis à infecção pelo vírus da hepatite $\mathrm{B}$ (VHB).

Dados obtidos em 1996 pela Dra. Maria Cássia Mendes Corrêa ${ }^{96}$, de pacientes atendidos no Serviço de Extensão ao Atendimento de Pacientes HIVIAids da Divisão de Clínica de Moléstias Infecciosas e Parasitárias do HCFMUSP ("Casa da Aids"), mostravam uma prevalência de $38,6 \%$ de anticorpos contra o antígeno do "core" do VHB (anti-HBc) entre 1693 pacientes infectados pelo HIV. A prevalência de antígeno de superfície (AgHBs) encontrada foi de $5,7 \%$.

Neste mesmo serviço (Casa da Aids), avaliamos, em inquérito orientado por nós e conduzido pela Dra. Ho, entre $1^{\circ}$ de janeiro e 30 de maio de 2000 , os marcadores sorológicos para o VHB de 191 dos 232 novos pacientes infectados pelo HIV admitidos. Encontramos $42 \%$ de pacientes com sorologia positiva para anti-HBc e $8,3 \%$ de portadores do $\mathrm{AgHBs}^{97}$. A co-infecção HIV/VHB era significativa em nosso meio, reforçando a importância da vacinação contra hepatite $B$.

Algumas estratégias para melhorar a resposta à vacinação contra hepatite $B$ já vinham sendo relatadas na literatura, principalmente relacionadas a outras condições de imunocomprometimento, que também condicionam hiporresponsividade à vacina. Por exemplo, Kapoor ${ }^{98}$ e Sudhagar ${ }^{99}$ usaram o fator estimulador de colônias de granulócitos e macrófagos (GM-CSF) como adjuvante vacinal em pacientes nefropatas sob diálise. O GM-CSF mostrou-se um adjuvante seguro e capaz de melhorar as taxas de soroconversão pós-vacinação. Seu alto custo e baixa disponibilidade, particularmente nos países pobres, não permitem, entretanto, seu uso rotineiro.

Em relação aos pacientes com HIVIAids alguns autores propunham o dobro da dose habitual, à semelhança do preconizado para os nefropatas ${ }^{100,}{ }^{101}$. Em 1999 o Ministério da Saúde do Brasil passou a recomendar o uso de dosagem em dobro, em cada uma das três doses habituais ${ }^{28}$. A partir de novembro de 2002 , passou a recomendar o esquema de quatro doses (0, 1, 2, 6 a 12 meses), mantendo a dosagem em dobro ${ }^{102}$.

A falta de referências consistentes embasando tais condutas nos levou a elaborar, orientando a pós-graduanda de doutorado Marise Oliveira Fonseca, projeto para avaliar a soroconversão a três doses da vacina recombinante contra hepatite B em pacientes adultos, infectados pelo HIV. Foram comparados dois esquemas de dosagem: 1 ) dose habitual ( $20 \mu \mathrm{g}$ de AgHBs por dose) e 2) dose em dobro (40 $\mu \mathrm{g}$ de AgHBs por dose). De novembro de 2000 a maio de 2002, foram incluídos no estudo 231 pacientes, dos quais 208 (90\%) foram alocados aleatoriamente nos dois grupos de investigação ${ }^{103}$. As características demográficas de ambos os grupos eram semelhantes. Completaram o esquema 
de três doses de vacina 192 pacientes (92,3\%). Os pacientes que receberam a dose em dobro da vacina contra hepatite $B$ apresentaram maior proporção de soroconversão $(46 / 98 ; 47 \%)$ que os pacientes que receberam a vacina na dose habitual (32/94; 34\%). Embora a diferença observada não tenha sido estatisticamente significativa à análise univariada $(p=0,07)$, esta diferença se manteve no modelo logístico (Odds Ratio ajustado=2,16; Intervalo de confiança de $95 \%=1,12$ a 4,$13 ; p=0.02$ ).

Não houve diferença quanto ao relato de eventos adversos entre os pacientes que receberam a dose em dobro e a dose habitual, e nem relato de eventos adversos graves.

Também neste estudo não houve variação significativa, após vacinação contra hepatite $\mathrm{B}$, da média da contagem de células CD4 e do logaritmo decimal da carga viral do HIV.

Os dados relatados, obtidos com casuística significativa e metodologia adequada, embasam a recomendação de utilização da dose em dobro da vacina contra hepatite B, para pacientes adultos infectados pelo HIV. Este foi um dos primeiros estudos em adultos infectados pelo HIV conduzido com o objetivo de comparar a resposta sorológica pós-vacinação contra hepatite B com dose habitual e com dose em dobro.

\subsubsection{Qual o melhor momento para iniciar a vacinação?}

Os estudos iniciais de vacinação em pacientes HIV/Aids recomendavam vacinação precoce, logo após ter sido feito o diagnóstico, uma vez que, a partir deste momento, haveria progressiva deterioração da resposta imunológica do indivíduo ${ }^{104}$. A introdução da terapêutica anti-retroviral de alta potência tem levado, na maioria dos pacientes, à reconstituição, pelo menos parcial, do sistema imune. Este aspecto deve ser considerado quando da indicação de vacinação para os pacientes HIV/Aids.

$\mathrm{Na}$ pesquisa conduzida no CRIE HC SP e relatada acima ${ }^{103}$, uma maior proporção de soroconversão esteve fortemente associada à contagem de células CD4 $\geq 350 / \mathrm{mm}^{3}$, associação demonstrada tanto na análise univariada quanto na multivariada. Os pacientes com níveis de carga viral $<10.000$ cópias $/ \mathrm{mL}$ apresentaram taxa de soroconversão significativamente maior que os com níveis de carga viral $\geq 10.000$ cópias $/ \mathrm{mL}$.

Estes dados nos levaram a concluir pela recomendação do uso do dobro da dose da vacina contra hepatite $B$, no momento de menor comprometimento do sistema imune, em pacientes infectados pelo HIV e ainda suscetíveis à infecção pelo vírus da hepatite $\mathrm{B}$. Ou seja, diferentemente do que se preconizava anteriormente, o momento ideal para vacinação, nestes pacientes, é aquele em que o paciente apresenta índices de contagem de células CD4 pelo menos superiores a 350 células $/ \mathrm{mm}^{3}$. Nos pacientes com baixa contagem de CD4 no momento do diagnóstico recomenda-se adiar a vacinação até que haja indícios de reconstituição do sistema imune. 


\section{COMENTÁRIOS}

A imunização no Brasil é uma história de sucesso, na opinião unânime dos estudiosos do assunto. Isto posto, não significa que ainda não haja desafios, que ainda não haja muita coisa por ser feita. É sob esta ótica que se discute a operacionalização de um serviço de vacinação, no caso específico, do Centro de Imunizações do Hospital das Clínicas da Faculdade de Medicina da USP, que é um Centro de Referência para Imunobiológicos Especiais (CRIE).

A direção da Organização Mundial da Saúde (OMS) estabeleceu, em 1999, um Grupo Estratégico de Especialistas Consultores - Strategic Advisory Group of Experts (SAGE) - para orientar os trabalhos do departamento de imunizações, vacinas e produtos biológicos. A sexta reunião deste grupo ocorreu em Genebra, Suiça, entre 27 e 29 de outubro de 2004. O resumo dos principais pontos discutidos e das recomendações feitas foi publicado em janeiro de $2005^{105}$.

Este relato considera que os contextos nos quais os programas nacionais de imunização operam têm se alterado dramaticamente. Ressaltam os avanços obtidos: o maior número de crianças que estão sendo protegidas contra doenças; os progressos no controle da poliomielite; a redução na mortalidade por sarampo. Discutem, entretanto, que a vacinação mundial, atualmente, se defronta com alguns desafios, dos quais destacam quatro pontos: 1) como consolidar os ganhos obtidos até o momento, tanto do ponto de vista de gestão, como financeiro; 2) como assegurar um acesso igualitário às novas vacinas; 3 ) como controlar doenças tais como influenza aviária, síndrome respiratória grave aguda (SARS na língua inglesa), infecção pelo HIV e Aids, para as quais ainda não se dispõe de vacinas comercializadas; 4) como financiar as novas e caras vacinas, atualmente disponíveis, assim como aquelas que o estarão dentro em breve.

O SAGE enfatiza a necessidade urgente de se encontrar recursos financeiros, na tentativa de vencer estes desafios. Mas observa que, simultaneamente, a obtenção destes recursos cria desafios administrativos e de infra-estrutura para gerenciá-los. Os países mais necessitados são também aqueles menos bem equipados para gerenciar, na prática, a ajuda.

Neste aspecto reside o grande diferencial que explica, pelo menos em parte, o sucesso alcançado pela imunização em nosso país. O Brasil, através do $\mathrm{PNI}$, tem sabido gerenciar os recursos obtidos.

Os responsáveis pelo PNI têm, ao longo dos últimos 30 anos, conseguido alcançar altas e homogêneas coberturas vacinais, através da rotina dos serviços de saúde pública e das campanhas anuais de vacinação. Mas têm também melhorado o controle de qualidade dos imunobiológicos ofertados à população, implementando redes de frio nos níveis local, estadual e nacional, e qualificando recursos humanos. Têm estimulado uma política nacional de auto-suficiência, em que pese que esta esteja muito aquém das necessidades do país. $E$, na tentativa de ampliar o acesso aos imunógenos disponíveis, estabeleceram um programa de suprimento de imunobiológicos, ditos especiais, para grupos específicos da população.

Embora a grande preocupação do SAGE seja o desafio financeiro que representa a manutenção e implementação das ações de vacinação, ao enumerar os desafios coloca em primeiro lugar a preocupação quanto a como consolidar, manter e gerir as aquisições atuais. Sob este ponto de vista, é importante que se 
discuta as diretrizes gerais do PNI e em particular de um de seus programas, os Centros de Referência para Imunobiológicos Especiais (CRIEs).

Os CRIEs podem ter um papel importante no gerenciamento da distribuição de novos imunógenos, ainda que não de maneira igualitária, mas de forma racional, levando em consideração aspectos epidemiológicos locais. Para isso terão de abrir espaço para discussões de estratégia, elaborar projetos de investigação científica e servir de pólo de disseminação de conhecimentos. As discussões de estratégias passam pela descentralização da distribuição dos imunógenos especiais, o que facilitaria o acesso ao produto, mas permanecendo o CRIE como responsável pelas ações na região de sua abrangência. Não deverão e não poderão ocupar o espaço das coordenadorias estaduais de imunização, nem dos comitês assessores. Deverão, isto sim, ocupar espaço enquanto produtores de conhecimento, que possibilitem vencer alguns dos desafios atuais.

Com o intuito de introduzir subsídios para esta discussão, sem a pretensão de fazê-la neste documento, propusemo-nos a descrever as atividades de um dos Centros de Referência para Imunobiológicos Especiais, o alocado no Centro de Imunizações do Hospital das Clínicas da Faculdade de Medicina da USP.

$\mathrm{Na}$ introdução de "O livro da meningite: Uma doença sob a luz da cidade", Cristina Fonseca, José Cássio de Moraes e Rita Barradas Barata escrevem: "A história, de fato, é uma ciência que dá possibilidade de se analisarem os fatos e feitos humanos no decorrer da linha do tempo, olhando-se para trás apenas para pensar no futuro" 106 .

É pensando no futuro que discorremos sobre a inserção de um Centro de Imunizações em um hospital universitário, e defendemos esta ligação por vezes não compreendida.

Desde a implantação desse Serviço e ao longo dos anos, percebemos que a possibilidade do Centro de Referência para Imunobiológicos Especiais estar ligado a uma instituição de ensino amplia seu campo de ação, e traz dividendos também para a instituição de ensino.

Para exercer as funções de centro de referência, a equipe que nele atua tem de ser qualificada e estar envolvida no trabalho. Isto compreende: estar cientificamente atualizada, ter disponibilidade para atender as mais diversas solicitações, e ser didática, pois atua como pólo difusor de conhecimento.

Mesmo obedecendo rigorosamente às normas de dispensação estabelecidas pelo $\mathrm{PNI}$, a complexidade que permeia a indicação de imunobiológicos para diferentes patologias, condições de imunocomprometimento e faixas etárias traz indagações que estimulam a pesquisa científica. A equipe tem de estar preparada para responder a esta demanda, não se constituindo em meros dispensadores de imunobiológicos. Nesta visão de trabalho cabe inclusive o encaminhamento de propostas de alterações das normas vigentes.

Este tipo de atuação demanda tempo, reuniões de planejamento, discussões de temas polêmicos, elaboração de protocolos de pesquisa.

Foi este o espírito que norteou o trabalho desenvolvido no CRIE HC SP nos últimos 10 anos. Cumprir rigorosamente as normas estabelecidas, mas ir além, nos valendo das oportunidades oferecidas pela instituição de ensino a que estamos ligados. $\mathrm{O}$ rigor do cumprimento das normas deriva da consciência de que estamos gerindo um bem público. $O$ ir além tem muito a ver com o prazer de 
trabalhar, estudar, buscar novos dados, caminhar. A alta complexidade do Hospital das Clínicas da Faculdade de Medicina da USP enseja o encaminhamento de pacientes com situações vacinais mais difíceis de serem resolvidas. Mas proporciona também mais amplas possibilidades de investigação científica, através da inter-relação com outros serviços e com diferentes grupos de pesquisa. Nem sempre as articulações com outros grupos são fáceis; exigem discussões francas, trabalho árduo de todas as partes envolvidas, definições bem estabelecidas de responsabilidade. $\mathrm{O}$ aprendizado resultante destas parcerias tem compensado o esforço despendido.

A orientação do PNI, quer sob a forma de manuais, instruções de serviço, reuniões de todos os CRIEs para discussões de trabalho e atualização científica, representou importante papel nestes anos todos. O apoio da Divisão de Imunização da Secretaria de Estado da Saúde de São Paulo foi essencial para a concretização das ações do CRIE. Mais profícua poderia ter sido esta relação se as reuniões de trabalho fossem mais freqüentes, obedecendo periodicidade programada.

O número de imunógenos dispensados aumentou, assim como o número de programas de atendimento, mas as atuações de maior impacto decorreram das atividades de ensino e pesquisa.

Os CRIES podem servir como importante instrumento de ensino.

Foi através das muitas aulas e palestras que se conquistou a confiança, por exemplo, dos funcionários do complexo HC/FMUSP, resultando em campanhas de vacinação de grande alcance. Está sendo através de seminários, cursos de atualização, que se está tentando obter o interesse de alunos de graduação e médicos residentes, para o campo das imunizações, ainda considerado por alguns, mesmo no meio científico, como assunto de importância secundária. As atividades didáticas têm ampliado os conhecimentos sobre este tema, além de servirem de instrumento de capacitação. O CRIE HC SP tem sido, também, local de estágio de profissionais que, posteriormente, foram atuar como médicos de família.

Mas, sem dúvida, são os trabalhos de investigação científica que melhor traduzem a ação do CRIE HC SP. Qual a melhor maneira de se estabelecer, na prática, a via de administração da vacina contra hepatite $B$ em crianças com discrasia sangüínea, senão através de investigação científica que conclui pela viabilidade do uso da via subcutânea?

Do mesmo modo, mais fácil do que tentar impor calendários de vacinação à equipe de transplante renal foi propor investigação conjunta, que amplia conhecimentos e conquista parceiros.

Foram os trabalhos apresentados em congresso sobre a vacina contra influenza e contra pneumococo 23-valente, realizados em conjunto com a Divisão de Clínica de Geriatria, que alertaram os geriatras para a possibilidade de encaminharem seus pacientes ao Centro de Imunizações do próprio HC, até então desconhecido de alguns deles.

Foi através dos relatos de nossa experiência com o atendimento de profissionais de saúde vítimas de acidentes com material biológico que se consolidou este programa. 
Foi a avaliação do programa de vacinação dos estudantes de medicina que nos mostrou claramente as falhas, e a necessidade de ajustes.

Mas o crescimento da equipe do Centro de Imunizações do HC teve muito a ver com as investigações conduzidas em pacientes imunodeprimidos, particularmente os infectados pelo HIV. Estas investigações confirmam os achados relatados na literatura de reduzida resposta à vacinação em pacientes imunodeprimidos. Mas confirmam também a ausência de eventos adversos mais graves relacionados à vacinação nestas pessoas e, particularmente nos pacientes HIV/Aids, a ausência de alterações significativas nos parâmetros laboratoriais e no curso clínico da infecção pelo HIV. Estes dados, obtidos com casuística composta pelos nossos pacientes do dia-a-dia, nos dão mais segurança em relação às condutas a serem adotadas.

A tentativa de buscar respostas, a obtenção de alguns resultados, a publicação dos mesmos em revistas científicas têm sido um estímulo contínuo para o trabalho do dia-a-dia.

Para a condução de nossos projetos de pesquisa buscamos financiamento, através da Universidade, junto aos órgãos de fomento. Nunca recebemos auxílio para pesquisa do PNI. É neste sentido que nos propomos a discutir o papel dos CRIEs. Esta estrutura pode ser melhor aproveitada.

Nestes 10 anos como responsável pelo CRIE HC SP vimos que, além da atividade assistencial, útil e necessária, há perspectivas deste espaço organizado ser utilizado para pesquisa aplicada. Pesquisa esta que, como procuramos fazer nestes anos, dê suporte às nossas condutas e possa, pelo menos um pouco, aclarar as nossas muitas dúvidas. Mantivemos sempre uma postura de independência de pensamento, sem nos atrelarmos a projetos pré-estabelecidos por outros, que, embora às vezes vantajosos do ponto de vista financeiro, pouco contribuem para ampliar os conhecimentos de que necessitamos.

As instituições de ensino têm muito a lucrar nesta parceria com os CRIEs. A estrutura permite atividades didáticas e investigação científica, pilares da vida acadêmica. O tema "Imunizações" é bastante adequado para o processo ensino / aprendizagem de como se faz pesquisa. Os estudos analíticos, tanto os de intervenção, como ensaios clínicos, quanto os observacionais, como casocontrole, coorte, série de casos, podem ser aprendidos a partir da investigação sobre vacinas. A epidemiologia constitui importante instrumento para pesquisa na área da saúde, seja no campo da clínica, seja no da saúde pública. Os ensaios controlados usados para avaliação de vacinas têm importância crescente nos dias atuais, principalmente por causa do grande número de novos produtos disponíveis. $O$ estudo dos eventos adversos provocados pelas vacinas também têm despertado muito interesse. À medida que as doenças imunopreveníveis vão ficando raras, a preocupação se transfere da doença para os efeitos adversos causados pela vacina. Os estudos epidemiológicos têm um papel crítico em quase todas as etapas de um programa de imunização de sucesso ${ }^{107}$.

Para que esta parceria seja mais profícua, na prática, os CRIEs necessitam de apoio financeiro específico para os projetos de pesquisa aí desenvolvidos. Apoios estes que seriam intermediados pelo PNI, e poderiam advir de diferentes fontes pagadoras, eventualmente até de instituições internacionais. Esta parceria CRIE/instituição de ensino deveria ter mecanismos de avaliação, que 
periodicamente seriam discutidos e analisados. Mas só o apoio financeiro não é suficiente para a realização plena dessa parceria. Os CRIEs, através de seus responsáveis, deveriam participar mais ativamente das Comissões Assessoras em Imunização estaduais e também ser representados na Comissão Assessora nacional. O envolvimento compromete. O compromisso estimula a ação.

O fato de ter sido convidada a participar da Comissão Permanente de Assessoramento em Imunizações do Estado de São Paulo, pelo seu presidente, professor Gabriel Oselka, a partir de 2001; e de ter sido indicada membro do Comitê Técnico Assessor de Imunizações (CTAI) nacional, representando a Sociedade Brasileira de Infectologia, desde 07/10/2003, foi um ganho pessoal muito grande. Aprende-se muito nestas comissões, que propiciam uma visão geral dos diversos aspectos envolvidos em imunizações. As eventuais contribuições que possamos dar exigem embasamento, que demanda muito estudo.

Se houvesse espaço para representantes dos CRIEs nestas comissões, mais uma vez as vantagens seriam bilaterais. As instituições de ensino estariam contribuindo, através dos representantes dos CRIEs, que, por sua vez, são do corpo da instituição, para as questões de saúde da coletividade. Sendo partícipes estariam mais compromissadas. Sendo beneficiadas com incentivos à pesquisa, seriam mais produtivas. As comissões lucrariam, ainda mais do que ocorre agora, com o rigor da metodologia da investigação e atualização científicas que permeiam o meio acadêmico.

Enfim, o que discuto, é que esta atividade que vimos desenvolvendo no CRIE HC SP ao longo dos últimos 10 anos poderia servir não como modelo, mas como ponto de partida para se repensar o papel dos CRIEs no cenário nacional.

A possibilidade de atuarem como centros de vacinação em geral, e não exclusivamente como dispensadores de imunobiológicos especiais, amplia seu campo de ação, facilita o encaminhamento de eventos adversos ligados à vacinação, e propicia aos que nele trabalham uma visão mais ampla dos vários aspectos envolvidos no Programa Nacional de Imunizações.

Um espaço organizado, onde as atividades desenvolvidas são analisadas, pensadas, discutidas, abre as portas para muitas outras atividades correlatas. Foi assim que "nasceram" o programa de atendimento aos profissionais do complexo HC/FMUSP vítimas de acidentes com material biológico, a imunização de viajantes. É assim que estão "nascendo" novas atividades como a parceria com a disciplina de imunologia, para investigação de eventos adversos ligados à vacinação.

Quase ao fim dessas considerações percebo com nitidez que, não intencionalmente, nós, a equipe do CRIE HC SP, seguimos as regras básicas do curso de "Leadership", que fiz na Universidade de Illinois, em 1997, baseadas nos ensinamentos de Kouzes e Posner ${ }^{108}$ :

- Desafiando o estabelecido: Nos aventurando. Vacinando transplantados com vacinas de vírus vivos; buscando alternativas para os infectados pelo HIV, respeitando sempre os preceitos éticos estabelecidos.

- Inspirando uma visão compartilhada: Não existe liderança sem seguidores. Os líderes não podem forçar o compromisso, mas podem inspirá-lo. E foi assim que, à equipe formal de trabalho, foram se agregando os alunos de iniciação científica, os estagiários, os entusiastas pós-graduandos. E a 
partir daqui estas pessoas estão inspirando esta visão em outros serviços, como a Sigrid e a Tânia, e em outras Universidades como a Marise.

- Permitindo que os outros ajam: A liderança é um esforço coletivo. Ninguém dá o melhor de si se se sente fraco, incompetente ou alienado. É assim que temos procurado nortear e manter nosso ambiente e nossas parcerias de trabalho.

- Apontando o caminho: Procuramos conquistar respeito pelo nosso comportamento. Os nossos atos foram sempre coerentes com nossas palavras e nossas idéias.

- Encorajando o coração (Encouraging the heart, na língua inglesa): Reconhecendo e incentivando a participação de todos os envolvidos nesse caminhar.

"Este olhar para trás" foi relatado para se pensar no futuro.

Ao longo de quase uma década e meia construí um projeto de trabalho engajado às necessidades de saúde da coletividade, pautado na prevenção, através do qual procurei aprender, ensinar e investigar. Algumas etapas foram concluídas, mas o projeto é contínuo e dinâmico, deve ir se transformando e sendo incorporado por outros.

\section{REFERÊNCIAS}

1- Plotkin SL, Plotkin AS. A short history of vaccination. In: Plotkin S, Orenstein W, editors. Vaccines. $4^{\text {th }}$ ed. Philadelphia: WB Saunders; 2004. p.1-5.

2- Silva LJ. Vacinas de uso restrito ou em desuso. III. Varíola. Imunizações. 2002;4(1-2):13-9.

3- Carvalho ES. Varíola. In: Farhat CK. Fundamentos e práticas das imunizações em clínica médica e pediatria. $3^{\mathrm{a}}$ ed. Rio de Janeiro: Atheneu; 1989. p.221-7.

4- Plotkin AS, Rupprecht CE, Koprowski H. Rabies vaccine. In: Plotkin S, Orenstein W, editors. Vaccines. $4^{\text {th }}$ ed. Philadelphia: WB Saunders; 2004. p.1011-38.

5- Fulginiti VA. History and overview. In: Fulginiti JB, editor. Immunization in clinical practice. New York: J.B. Lippincott Company; 1982. p.1-10. 
6- Sutter RW, Kew OM, Cochi SL. Poliovirus Vaccine Live. In: Plotkin S, Orenstein W, editors. Vaccines. $4^{\text {th }}$ ed. Philadelphia: WB Saunders; 2004. p.651-705.

7- Katz SL, Kempe $\mathrm{CH}$, Black FL. Studies on an attenuated measles virus vaccine. VIII. General summary and evaluation of results of vaccine. $N$ Engl $J$ Med. 1960;263:180-4.

8- Hilleman MR, Buynak EB, Weibel RE, Stokes J Jr. Live attenuated mumpsvirus vaccine. N Engl J Med. 1968;278:227-32.

9- Salk JE, Krech U, Youngner JS. Formaldehyde treatment and safety testing of experimental poliomyelitis vaccines. Am J Public Health. 1954;44:563-70.

10-Atkinson WL, Pickering LK, Watson JC, Peter G. General immunization practices. In: Plotkin S, Orenstein W, editors. Vaccines. $4^{\text {th }}$ ed. Philadelphia: WB Saunders; 2004. p.91-122.

11-Lopes MH. Tecnologias ampliam perspectivas da imunização. O Estado de São Paulo, São Paulo. 1995 jul 02. Caderno 2.

12-Hadler SC, Cochi SL, Bilous J, Cutts FT. Vaccination programs in developing countries. In: Plotkin S, Orenstein W, editors. Vaccines. $4^{\text {th }}$ ed. Philadelphia: WB Saunders; 2004. p.1407-41.

13-Santos AR. Imunização. In: Rouquayrol MZ, colaboradores. Epidemiologia \& saúde. $3^{\mathrm{a}}$ ed. Rio de Janeiro, MEDSI;1988. p.289-317.

14-Quadros CA. 100 Years of vaccine and immunization in the Americas. In: Conference on Vaccines, Prevention and Public Health: a vision for the future. Washington, DC: Pan American Health Organization; 2202. Abstracts.

15-PAHO. Technical Advisory Group (TAG). A culture of prevention: A model for control of vaccine-preventable diseases. XVI Meeting of the Technical Advisory Group on vaccine-preventable diseases. Cidade do México, 3 a 5 de novembro de 2004. [online] [citado 30 jan 2005]. Disponível em: www.paho.org/English/AD/FCH/IM/TAG16_conclusions.pdf 
16-Ministério da Saúde. Fundação Nacional de Saúde. Centro Nacional de Epidemiologia. Coordenação do Programa Nacional de Imunizações. Manual de procedimentos para vacinação. $3^{\text {a }}$ ed. Brasília: Fundação Nacional de Saúde; 2000.

17-Ministério da Saúde do Brasil. Secretaria de Vigilância em Saúde. Programa Nacional de Imunizações 30 anos. Série C. Projetos e Programas e Relatórios. Brasília, DF; 2003.

18-Centro de Vigilância Epidemiológica (CVE) "Professor Alexandre Vranjac" da Secretaria de Estado da Saúde de São Paulo. Divisão de Imunização. Divisão de Doenças Transmissíveis Respiratórias. Informe Técnico. Campanha nacional de vacinação contra o sarampo e poliomielite. 21.08 a 03.09.2004 [online]. [citado 30 jan 2005]. Disponível em: ftp://ftp.cve.saude.sp.gov.br/doc tec/imuni/if sarpolio04.pdf

19-Centro de Vigilância Epidemiológica (CVE) "Professor Alexandre Vranjac" da Secretaria de Estado da Saúde de São Paulo. Sarampo. Casos confirmados, coeficiente de incidência, óbitos e letalidade. Estado de São Paulo - 1992 a 2004 [online] [citado 30 jan 2005]. Disponível em: http://www.cve.saude.sp.gov.br/htm/resp/Sara con.htm

20-Centro de Vigilância Epidemiológica (CVE) "Professor Alexandre Vranjac" da Secretaria de Estado da Saúde de São Paulo. Informe técnico. Sarampo e rubéola - 2003.[online] [citado 30 jan 2005]. Disponível em: ftp://ftp.cve.saude.sp.gov.br/doc tec/resp/if sarub.pdf

21-Centro de Vigilância Epidemiológica "Professor Alexandre Vranjac" da Secretaria de Estado da Saúde de São Paulo. Varicela: Distribuição de ${ }^{\circ}$ de casos, $\mathrm{n}^{\circ}$ de óbitos, coeficientes de incidência e letalidade, segundo faixa etária. Estado de São Paulo, 2002 a 2004. [online] [citado 30 jan 2005]. Disponível em: http://www.cve.saude.sp.gov.br/htm/resp/vari tab.htm

22-Ministério da Saúde. DATASUS. Informações de Saúde. Imunizações cobertura [online] [citado 25 jan 2005]. Disponível em: http://tabnet.datasus.gov.br/cgi/pni/cpnimap.htm

23-Secretaria de Vigilância em Saúde. SVS. Imunizações. Números da vacinação no Brasil. Evolução da cobertura vacinal de rotina em menores de um ano 
1980 a maio de 2004 [online]. [citado 25 jan 2005]. Disponível em: http://dtr2001.saude.gov.br/svs/imu/evolucao rotina.ppt

24-Secretaria de Vigilância em Saúde. SVS. As doenças transmissíveis no Brasil. Gráficos de evolução das doenças. (1980 - 2003) [online]. [citado 25 jan 2005\}. Disponível em: http://dtr2001.saude.gov.br/svs/epi/situacao doencas/graficos dnc 190804. pdf.

25-Ministério da Saúde. DATASUS. População residente - Brasil [online]. [citado 25 jan 2005]. Disponível em: http://tabnet.datasus.gov.br/cgi/deftohtm.exe?ibge/cnv/popuf.def.

26-Termo de Cooperação Técnica. Diário Oficial do Estado. 16/04/1992. página 31.

27-Brasil. Ministério da Saúde. Norma para os centros de referência para imunobiológicos especiais. Brasília; 1993.

28-Brasil. Ministério da Saúde. Manual dos centros de referência de imunobiológicos especiais. Brasília; $2^{\mathrm{a}}$ ed. 1999.

29-Brasil. Ministério da Saúde. Manual dos centros de referência de imunobiológicos especiais. Fundação Nacional de Saúde. Brasília; $2^{a}$ ed. rev. 2001.

30-Lopes MH, Tengan FM, Bianchin PJ, Sartori AM, Aranda CMS, Omoto TM, A RMM, Oselka GW, Costa WA, Amato NetoV. Relato do primeiro ano de atividade do Centro de Referência em Imunobiológicos Especiais de São Paulo. Rev Soc Bras Med Trop.1995; 28(supl 1):316.

31-Entrevista: Centro de Imunizações aplica quase 12.000 doses em 1996. Seção: Conheça o ICHC. Boletim do Instituto Central do Hospital das Clínicas da FMUSP.1997;1(11):2.

32-Boletim do Instituto Central do Hospital das Clínicas da FMUSP. Vacinação contra o sarampo no HC. 1997;1(11):1. 
33-Vacinação contra Hepatite B. HC em Notícias. Informativo do Hospital das Clínicas da Faculdade de Medicina da USP. n 8145. Out. 2004. p.2.

34-Tengan FM, Lopes MH, Sartori AMC, Bianchin PJ, Andreoli RMM, Amato Neto V. Profilaxia pós exposição, para hepatite B e C, em profissionais de saúde. Rev Soc Bras Med Trop. 1995;28(supl 1):199.

35-Centers for Disease Control and Prevention (CDC). Updated U.S. Public Health Services Guidelines for the Management of Occupational Exposures to HBV, $\mathrm{HCV}$, and HIV and Recommendations for Post-Exposure Prophylaxis. MMWR Morb Mortl Wkly Rep 2001;50. N RR 11.

36-Lopes MH, Tengan FM, Gutierrez EB, Carlesi ER, Possani JF, Tapajós R, Medeiros EAS, Shikanai-Yasuda MA. Relato de implantação de serviço de profilaxia após acidente com material biológico no Hospital das Clínicas da Faculdade de Medicina da Universidade de São Paulo. Rev Soc Bras Med Trop. 1999;32(supl 1):103.

37-Ministério da Saúde. Manual de condutas em exposição ocupacional a material biológico. 2004 . [online]. $\quad$ Disponível em: http://www.aids.gov.br/assistência/manual exposição ocupa.htm. Acesso em: 15 mar 2004.

38-Gutierrez EB, Lopes MH, Shikanai-Yasuda MA. Accidental exposure to biological material in healthcare workers at a university hospital: evaluation and follow up of 404 cases. Scand J Infect Dis. in press 2005.

39-Lauvelt A. The role of skin dendritic cells in the inibition of human immunodeficiency virus infection. Am J Med. 1997;102(Suppl 5):16-20.

40-Pinto LA, Landay AL, Berzofsky JA, Kessler HA, Shearer GM. Immune response to human immunodeficiency virus (HIV) in healthcare workers occupationally exposed to HIV-contamined blood. Am J Med. 1997;102 (Suppl 5B):21-4.

41-Kuhn L, Mrfofows-Taylor S, Gray B, Tiemessen C. Human immunodeficiency virus (HIV) - specific cellular immune responses in newborns exposed to HIV in utero. Clin Infect Dis. 2002;34:267-76. 
42-Cardo D, Culver D, Ciesielsky CA, Srivastava PU, Marcus R, Abiteboul D, Heptonstall J, Ippolito G, Lot F, McKibben PS, Bell DM. A case-control study of HIV seroconversion in health care workers after percutaneous exposure. $N$ Engl J Med. 1997;337(21):1485-90.

43-Jaeckel E, Cornberg M, Wedemeyer H, Santantonio T, Mayer J, Zankel M, Pastore G, Dietrich M, Trautwein C, Manns MP. Treatment of acute hepatitis C with interferon alpha. N Engl J Med. 2001; 345(20):1452-7.

44-Bianchin PJ, Lopes MH, Tengan FM, Amato Neto V. Freqüência dos eventos adversos das vacinas contra o Haemophilus influenzae b e contra o pneumococo em 54 crianças imunocomprometidas. Rev Soc Bras Med Trop. 1995;28(supl 1):62.

45-Hasegawa EM, Lopes MH, Gutierrez EB. Avaliação de programa de vacinação para estudantes de medicina. Bol Soc Bras Imunizações. 2000;3(4):4-8.

46-Oliveira MS, Vilas Boas G, Boulos MIC, Lopes MH. Vacinação em gestantes infectadas pelo vírus da imunodeficiência humana. In: XXXVII Congresso da Sociedade Brasileira de Medicina Tropical. Salvador; 2001. Anais.

47-Ferron MM, Lopes MH, Pereira RTMC, Gutierrez EB. Perfil do conhecimento dos internos e residentes do HCFMUSP sobre profilaxia de tétano. Rev Soc Bras Med Trop. 2002;35(supl 1):154.

48-Amato JGP, Lopes MH, Amato VS, Amato Neto V. Departamento de Doenças Infecciosas e Parasitárias da Faculdade de Medicina da Universidade de São Paulo Imunizações em infectados pelo Vírus da Imunodeficiência Humana (HIV). São Paulo: CLR Balieiro, 1997.

49-Santos MV, Lopes MH. Vacina inativada contra Hepatite A: revisão da literatura e considerações sobre seu uso. Rev Soc Bras Med Trop. 1997;30(2):145-57.

50-Lopes MH, Amato Neto V. Imunizações em pacientes infectados pelo HIV. Imunizações. 1997;1(1):27-8. 
51- Lopes MH, Amato Neto V. Vacinação de adultos. Imunizações.1997;1(1):2930.

52-Lopes MH. O Programa Nacional de Imunizações no Brasil e a cogitação de ampliação. Imunizações.1998;2(3):80-3.

53-Lopes $\mathrm{MH}$, Amato Neto $\mathrm{V}$. Vacinas recomendáveis para diabéticos. Imunizações. 1999;3(3):99-100.

54-Moussalem TM, Schout D, Lopes MH. Sarampo no HC-FMUSP: perfil clínico epidemiológico - 1989 a 2000. Rev Soc Bras Med Trop. 2002;35(supl 1):390.

55-Lopes MH. Vacinação na criança e no adulto. In: Manual de condutas médicas. Instituto para o Desenvolvimento da Saúde. São Paulo: Universidade de São Paulo, Ministério da Saúde; 2002. p.10-5.

56-Lopes MH. Imunização contra a Raiva. In: Amato Neto V, Baldy JLS, Silva LJ. Imunizações. $3^{a}$ ed. São Paulo: Sarvier; 1991. p.169-76.

57-Lopes MH. Meningites bacterianas agudas. Profilaxia e vacinas. In: Machado LR, Livramento JÁ, Spina-França Netto A, Nóbrega JPS, editores. Neuroinfecção 96. São Paulo: Clínica Neurológica HC/FMUSP; 1996. p.149-58.

58-Lopes MH. Vacinação preventiva da hepatite $\mathrm{B}$ : obrigatoriedade em profissionais da área da saúde. In: Weckx LY, Amato Neto V. Controvérsias em imunizações. São Paulo: Lemos Editorial; 2002. p.47-9.

59-Lopes MH. Vacina preventiva da hepatite B em infectados pelo HIV: dose dupla também nos assintomáticos; uso independentemente da contagem de linfócitos CD 4 no sangue. In: Weckx LY, Amato Neto V. Controvérsias em imunizações. São Paulo: Lemos Editorial; 2002. p.59-62.

60-Carneiro JDA, Lopes MH. Immunogenicity of subcutaneous hepatitis B vaccine in children with congenital bleeding diseases. Haemophilia. 2000;6(4):319. 
61-Machado CM, Rocha IF, Sbrissa BD, Macedo MC, Massumoto C, Medeiros RS, Silva RL, Lopes MH, Dulley FL. Efetividade da vacinação contra hepatite B e persistência da imunidade após um ano em receptores de transplante de medula óssea. Brazilian J Infect Dis. 1997;1(suppl 1):S8.

62-Santos MV, Gutierrez EB, Sartori AMC, Warth MPTN, Tak HS, Hausen MP, Faro LBL, Lopes MH. Vacinação contra hepatite $B$ em alunos do primeiro ano do curso médico da FMUSP; experiência do Centro de Imunizações do HCFMUSP. Rev Soc Bras Med Trop 1999;32(supl 1I):187-8.

63-Rowan MS, Carter AO, Walker VJ. Immunization polices in Canadian medical schools. Can Med Assoc J. 1994; 151: 957-61.

64-Poland GA, Nichol KL. Medical schools and immunization policies: missed opportunities for disease. Ann Intern Med. 1990; 113: 628-31.

65-Lopes MH. Vacinação de adultos. Boletim do Corpo Clínico. Hospital das Clínicas da FMUSP. 1996;76:3.

66-Secretaria de Vigilância em Saúde. SVS. Imunizações. Calendários de vacinação. [online]. [citado 30 jan 2005]. Disponível em: http://dtr2001.saude.gov.br/svs/imu/imu00.htm

67-Ferreira NL, Lerário AM, Gutierrez EB, Sartori AMC, Tengan FM, Paschoal SMP, Carvalho Filho ET, Andreoli RMM, Duarte Y, Lopes MH. Avaliação do Programa de Vacinação do Idoso no HCFMUSP, em São Paulo, SP. Rev Soc Bras Med Trop. 1998;31(supl 1):223.

68-Vieira VSD, Brandão AP, Brandileone MCC, Chiba T, Lopes MH, Yara T, Gorla MC, Ramos RCZ, Di Fabio JL, Jacob Filho W. Produção de anticorpos por indivíduos idosos após vacinação anti-Streptococcus pneumoniae: resultados preliminares. In: XX Congresso Brasileiro de Microbiologia. Salvador; 1999. Anais.

69-Velhote M, Chiaratto VC, Lopes MH, Sartori AMC, Gutierrez EB, Andreoli RMM, Paschoal SMP, Filhi ETC. Programas de vacinação de idosos no HCFMUSP. In: XV Brazilian Infectious Diseases Congress. São Paulo; 1999. Annals. 
70-Gutierrez EB, Lii HY, Santos ACS, Lopes MH. Effectiveness of influenza vaccination in elderly outpatients in São Paulo City, Brazil. Rev Inst Med Trop São Paulo. 2001;43(6):317-20.

71-Centers for Disease Control and Prevention (CDC). Prevention and control of influenza. MMWR Morb Mortl Wkly Rep. 1999;48:1-28. (Recomendations and Reports).

72-Chaves T, Lopes MH, Santos SS, Araújo LMP, Kakehashi E, Alves CF, DavidNeto E. Avaliação da situação da carteira vacinal de crianças transplantadas renais seguidas no ambulatório de urologia da Unidade de Transplante Renal da Divisão de Clínica Urológica do HCFMUSP, no período de outubro de 2001 a maio de 2002. Rev Soc Bras Med Trop. 2003; 36 (supl 1):391.

73-Chaves TSS, Lopes MH, Ueda VA, Santos SS, Pereira LM, Reis AD, DavidNeto E. Seroprevalence of antibodies against varicella-zoster virus and response to the varicella vaccine in pediatric renal transplant patients. Pediatr Transplant. 2005. In press.

74-Zamora I, Simon JM, Silva ME, Piqueras Al. Attenuated varicella virus vaccine in children with renal transplants. Pediatr Nephrol. 1994; 8:190-92.

75-Feldhoff CM, Balfour HH, Simmons RL, Najarian JS, Mauer SM. Varicella in children with renal transplants. J Pediatr. 1981;98:25-31.

76-Fehr T, Bossart W, Wahl C, Binswanger U. Disseminated varicella infection in adult renal allograft recipients: four cases and a review of literature. Transplantation. 2002;27:608-12.

77-Rothwell W, Gloor JM, Morgenstern BZ, Milliner DS. Disseminated varicella infection in pediatric renal transplant recipients treated with mycophenolate mofetil. Transplantation 1999;68:158-61.

78- Laube GF, Berger C, Goetschel P, Leumann E, Neuhaus TJ. Immunization in children with chronic renal failure. Pediatr Nephrol., 2002;17:638-42. 
79-Kanda Y, Mineishi S, Saito T, Saito A, Yamada S, Ohnishi M, Chizuka A, Niija $\mathrm{H}$, Suenaga K, Nakai K, Takeuchi T, Makimoto A, Tanosaki R, Kami M, Tanaka Y, Fujita S, Watanabe T, Kobayashi Y, Tobinai K, Takaue Y. Long-term lowdose acyclovir against varicella-zoster virus reactivation after allogenic hematopoietic stem cell transplantation. Bone Marrow Transplant. 2001;28:68992.

80-O'Brien WA, Grovit-Ferbas K, Namazi A, Ovcak-Derzic S, Wang HJ, Park J, Yeramian C, Mao SH, Zack JA. Human immunodeficiency virus-type 1. Replication can be increased in peripheral blood of seropositive patients after influenza vaccination. Blood. 1995;86:1082-9.

81-Stanley SK, Ostrowski MA, Justement JS, Gantt K, Hedayati S, Mannix M, Roche K, Schartzentruber DJ, Fox CH, Fauci AS. Effect of immunization with a common recall antigen on viral expression in patients infected with human immunodeficiency virus type 1. N Engl J Med. 1996;334:1222-30.

82-Brichacek B, Swindells S, Janoff EM, Pirruccello S, Stevenson M. Increased plasma human immunodeficiency virus type 1 burden following antigenic challenge with pneumococcal vaccine. J Infect Dis. 1996;174:1191-9.

83-Kroon FP. Program and abstracts of the $36^{\text {th }}$ Interscience Conference on Antimicrobial Agents and Chemotherapy. News Orleans; 1996. p.197. Annals.

84-Fowke KR, D'amico R, Chernoff DN, Pottage JC Jr, Benson CA, Sha BE, Kessler HA, Landay AL, Shearer GM. Immunologic and virologic evaluation after influenza vaccination of HIV-1 infected patients. AIDS. 1997; 11(8):101321.

85-Donovan RM, Moore E, Bush CE, Markowitz NP, Saravolatz LD. Changes in plasma HIV RNA levels and CD4 cells counts after vaccination of pediatric patients. AIDS. 1997; 11(8):1054-6.

86-Santos SS, Lopes MH, Simonsen V, Caiaffa-Filho HH. Haemophilus influenzae type $b$ immunization in adults infected with the Human Immunodeficiency Virus. AIDS Res Hum Retroviruses. 2004;20(5):493-6. 
87-Sullivan OS, Hanson DL, Dworkin MS. Adult and Adolescent Spectrum of HIV Diseases Investigators. Effect of influenza vaccination on disease progression among HIV-infected persons. AIDS. 2000; 4:2781.

88-Glesby MJ, Hoover DR, Farzadegan $\mathrm{H}$. The effect of influenza vaccination on human immunodeficiency virus type 1 load: A randomized, double-blind, placebo-controlled study. J Infect Dis. 1996;174:1332-6.

89-Glesby MJ. Immunizations during HIV infection. Curr Opin Infect Dis. 1998;11(1):17-21.

90-Steinhoff MC, Auerbach BS, Nelson KE, Vlahov D, Beckerr L, Graham NM, Schwartz DH, Lucas AH, Chaisson RE. Antibody responses to Haemophilus influenzae type $\mathrm{b}$ vaccines in men with human immunodeficiency virus infection. N Engl J Med. 1991;325:1837-42.

91-Hadler SC. Hepatitis B prevention and human immunodeficiency virus (HIV). Ann Intern Med. 1998;109:92-4.

92-Bruguera M, Cremades M, Salinas R, Costa J, Grau M, Sans J. Impaired response to recombinant hepatitis B vaccine in HIV infected persons. J Clin Gastroenterol. 1992;14:27-30.

93-Tayal SC, Sankar KN. Impaired response to recombinant hepatitis B vaccine in asymptomatic HIV infected individuals. AIDS. 1994;8:558-9.

94-Sasaky MGM, Mello RS, Siciliano RF, Wang L. Response of HIV/Aids patients to hepatitis B recombinant vaccine. Braz J Infect Dis. 1998;2:236-40.

95-Rey D, Krantz V, Partisani M, Schmitt MP, Meyer P, Libbrecht E, Wendling MJ, Vetter D, Kempf-Durepaire G, Lang JM. Increasing the number of hepatitis B vaccine injections augments anti-HBs response rate in HIV-infected patients. Effects on HIV-1 viral load. Vaccine. 2000;18:1161-5.

96-Mendes-Corrêa MCJ, Barone AA, Cavalheiro NP, Tengan FM, Guastini C. Prevalence of hepatitis $B$ and $C$ in the sera of patients with HIV infection in São Paulo, Brazil. Rev Inst Med Trop São Paulo. 2000;42:81-5. 
97-Ho YL, Fonseca MO, Santos ACS, Lopes MH. Prevalence of human immunodeficiency virus and hepatitis B virus co-infection in a specialized HIV university care center in Sao Paulo - Brazil. In: XIV International AIDS Conference. Barcelona; 2002. Annals.

98-Kapoor D, Aggarwal SR, Singh NP, Thakur V, Sarin SK. Granulocytemacrophage colony-stimulating factor enhances the efficacy of hepatitis $B$ virus vaccine in previously unvaccinated haemodialysis patients. $J$ Virol. Hepatol. 1999; 6:405-9.

99-Sudhagar K, Chandraseker S, Rao MS, Ravichandran R. Effect of granulocyte colony stimulating factor on hepatitis $B$ vaccination in haemodialysis patients. $J$ Assoc Physicians India. 1999;47:602-4.

100- Choudhury AS, Peters VB. Responses to hepatitis B vaccine boosters in human immunodeficiency virus-infected children. Pediatr Infect Dis J. 1995;14:65-7.

101- Scolfaro C, Fiammengo P, Balbo L, Madon E, Tovo PA. Hepatitis B vaccination in HIV-1 infected children: double efficacy doubling the paediatric dose. AIDS. 1996; 10:1169-82.

102- Ministério da Saúde. Recomendações para vacinação em pessoas infectadas pelo HIV [online]. [citado 15 mar 2004]. Brasília: Ministério da Saúde, Fundação Nacional da Saúde; 2002. Disponível em: http://www.funasa.gov.br/pub/pdfs/vacinacao-hiv.pdf

103- Fonseca MO, Pang LW, Cavalheiro NP, Barone AA, Lopes MH. Randomized trial of recombinant hepatitis B vaccine in HIV-infected adult patients comparing a standard dose to a double dose. Vaccine. 2005. In press.

104- Rodriguez-Barradas MC, Musher DM, Lahart C, Lacke C, Groover J, Watson D, Baughn R, Cate T, Crofoot G. Antibody to capsular polysaccharides of Streptococcus pneumoniae after vaccination of human immunodeficiency virus-infected subjects with 23-valent pneumococcal vaccine. J Infect Dis. 1992;165:553-6. 
105- WHO. Recommendations from the Strategic Advisory Group of Experts to the Department of Immunization, Vaccines and Biologicals. Weekly Epidemiological. 2005;2:11-8.

106- Fonseca C, Moraes JC, Barata RB. O livro da meningite: uma doença sob a luz da cidade. São Paulo: Editora Segmento Farma; 2004. p.15.

107- Chen RT, Orenstein WA. Epidemiologic methods in immunization programs. Epidemiol Rev. 1996;18(2):99-117.

108- Kouzes JM, Posner BZ. The Leadership Challenge. $2^{\text {nd }}$ ed. San Francisco: Jossey-Bass Inc., Publishers; 1995. 